\title{
Acción 1 BEPS. Metodología aplicación en Colombia Economía Digital - Negocio Streaming - Caso Netflix*
}

\section{Action 1 BEPS. Methodology application in Colombia Digital Economy-Business Streaming-Case Netflix}

\author{
Ana Cristina Triana Suárez ${ }^{1}$ \\ CARlos Humberto Aragón TrujILlo ${ }^{2}$
}

\section{Resumen}

La economía digital es una nueva forma de hacer negocios, que día a día va ganando terreno en la globalización de las operaciones mediante las cuales los diferentes Estados transan bienes, servicios y capitales. Este esquema se basa principalmente en las transacciones de intangibles, lo cual dificulta la fiscalización de las mismas por parte de los diferentes países, debido a vacíos en la normatividad tributaria doméstica de aquellos, lo cual limita la imposición de los diferentes tributos a las transacciones internacionales, abriendo una brecha para la evasión y/o elusión tributaria internacional, mediante el uso de estrategias de planificación agresiva por parte de los agentes económicos que intervienen en estas operaciones.

A raíz de ello, la Organización para la Cooperación y el Desarrollo Económicos (OCDE) incluyó dentro del Proyecto BEPS la Acción 1 (Desafíos de la economía digital), en la cual se realiza la contextualización, análisis y desarrollo de recomendaciones que los Estados

* DOI: https://doi.org/10.18601/16926722.n13.03

${ }^{1}$ Magíster en Tributación Internacional, Comercio Exterior y Aduanas de la Universidad Externado de Colombia, Contadora Pública de la Fundación Universitaria San Martin y Administradora Financiera de la Universidad del Tolima, funcionaria de la Dirección de Impuestos y Aduanas Nacionales.Correo-e: ana.triana03@estuexternado.edu.co

2 Magíster en Tributación Internacional, Comercio Exterior y Aduanas de la Universidad Externado de Colombia, Especialista en Finanzas de la Universidad del Rosario, Economista de la Universidad del Tolima, funcionario de la Dirección de Impuestos y Aduanas Nacionales.

Correo-e: carlosaragon@estuexternado.edu.co 
puede adoptar a fin de ajustar sus normas tributarias domésticas, que les permitan ser aplicadas a las transacciones internacionales.

Así las cosas, en el presente artículo se analiza este nuevo modelo económico, que se encuentra en el streaming prestado por diferentes multinacionales como Netflix, Spotify, HBO GO, Amazon Video, Mubi o Vudu, a fin de determinar sus características y evaluar si las normas tributarias colombianas vigentes permiten la imposición de los impuestos directos e indirectos sobre estas transacciones.

De acuerdo con lo anterior, se realiza una categorización de las rentas derivadas de estas transacciones, determinadas a partir del estudio de la legislación comercial, civil y tributaria que las enmarca y que las clasifica dentro de un tipo de renta especifica, como son los cánones o regalías.

En este contexto, se analiza la viabilidad de gravar con el impuesto de renta las operaciones objeto de estudio, y para ello se clasifican como los ingresos de fuente nacional. Así mismo, se evalúan los efectos de la Ley 1819 de 2016 en esta materia, toda vez que la norma ajustó la normatividad fiscal existente de los impuestos indirectos para hacerla extensiva a algunos servicios virtuales prestados desde el exterior, y dispuso los mecanismos de recaudo de estos.

Palabras clave: Economía digital, Streaming, Impuesto directo, Impuesto indirecto, Rentas de fuente nacional en Colombia, Ingreso gravado, Retención en la fuente, Cánones, Regalías, Derechos de propiedad intelectual, Tributación internacional, Acciones BEPS en Colombia.

\section{Abstract}

The digital economy is a new economic model that is gaining ground every day in the globalization of mediating operations, in which different states trade goods, services and capital; this new type of economy is mainly based on intangible transactions, which makes difficult for the different countries to inspect them, due to loopholes in the doméstic tax regulations established in each state, which limits the imposition of the different taxes to international transactions, opening a gap to tax evasion and / or international tax avoidance, through the use of aggressive planning strategies by the economic agents that intervene in this new type of economy.

Consequently, the "Organizacion para la Cooperación y el Desarrollo Económico $O C D E$ " (Organization for the Economic and Development Cooperation), included within the BEPS Project the Action 1 - Challenges of the digital economy, in which is carried on the contextualization, analysis and development of different recommendations that states can adopt, in order to adjust their doméstic tax regulations, which allow them to be applied to international transactions that are executed within the framework of this new economic model.

For this reason, this is why in this article we analyze one of the businesses that has had the most boom in the world, in this new economic model, such as the Streaming provided by different multinationals such as Netflix, Spotify, нво GO, Amazon Video, Mubi or Vudu that day by day position themselves in the global market, in order to determine their characteristics and evaluate if 
the current Colombian tax regulations allow the imposition of direct and indirect taxes on these transactions.

This evaluation is made from the categorization of the income derived from these transactions, determined from the study of the commercial, civil, and tax legislation that frames them and that classifies them within a specific income type, such as the Canons or Royalties.

Thus, analyzing from this perspective of this categorization the feasibility of taxing with the Income Tax classifying this type of income as national source income and also evaluating the possible turnaround in terms of the provisions of the structural tax reform adopted by the Law 1919 of 2016, which adjusted the existing fiscal regulations of indirect taxes to extend it to some virtual services provided from abroad and arranged the mechanisms for their retraction.

Keywords: Digital economy, Streaming, Direct tax, Indirect tax, National source income in Colombia, Taxable income, Withholding at source, Royalties, Intellectual property rights, International taxation, BEPS actions in Colombia.

\section{Evolución de la Economía digital y su contexto}

\section{A. Historia de la Economía digital y su desarrollo en Colombia}

Desde los inicios del internet, con el inglés Tim Berners Lee, considerado el padre de la web, se presentó el apogeo de los negocios a través de esta plataforma con los puntocoms, entre 1995 y 2001, con sitios como Starmedia, Terra, etc., que luego colapsaron y dieron pérdidas por más de 5 millardos de dólares, según NASDAQ (National Association of Securities Dealers Automated Quotation); sin embargo, este negocio siguió adelante y se consolidó a nivel internacional.

Según el Banco Mundial (2016), el $40 \%$ de la población mundial se encuentra conectada de alguna forma a internet. Así, de los 7.400 millones de personas, 2.960 se encuentran conectadas a internet, de las cuales, 1.100 millones tienen de alta velocidad.

En ese mundo virtual se desarrollan negocios, y según la Agencia de las Naciones Unidas para el Comercio y el Desarrollo (UNCTAD 2016), se mueven 25 billones de dólares, de los cuales el $90 \%$ corresponde a tratos entre empresas B2B, y el restante $10 \%$ al comercio B2C. Para el caso de Colombia, según las cifras registradas por la Cámara de Comercio Electrónico, en el año 2015 se generaron transacciones por valor de USD 16.329 millones.

Ahora bien, en dicha e-economía ${ }^{3}$, los intangibles serían los nuevos generadores de riqueza, pues negocios tradicionales han digitalizado sus bienes tangibles, migrando a la economía digital por razones de costos y mercadeo. Ejemplo de lo anterior es el caso del comercio al por menor de obras literarias y artísticas, software, entre otros, los servicios de logística, financieros, enseñanza,

${ }^{3}$ E-economía: Economía digital, término de creación del autor Carlos Humberto Aragón Trujillo, con el cual se resumen los nuevos modelos de negocio y de creación de valor de la era digital. 
medios de comunicación, publicidad, medicina, etc., desvaneciendo la línea entre la economía tradicional y la economía digital.

Esta realidad ha generado inconvenientes en la aplicación de la normatividad existente en el ámbito comercial, tributario e internacional, porque la mayoría de bienes transados son intangibles y esto hace difícil ubicar con exactitud al proveedor, al consumidor y el tipo de contrato, ello aunado a que al ser a través de internet, las mismas se pueden realizar entre agentes ubicados en diferentes jurisdicciones, obstaculizando así determinar la legislación aplicable.

Con ocasión a lo anterior, es necesario que la normatividad actual se ajuste a las tendencias de negociación que trae la economía digital, y que revista de la característica de flexibilidad que permita ajustarse a lo que existe hoy y lo que vendrá dado el cambio constante en los modelos de negocio y generación de valor de las nuevas tecnologías; es por ello que es necesario conocer y comprender los nuevos modelos de negocio y de ingreso que se desarrollan dentro de la e-economía y solo así lograr un avance en las normas que enmarcan toda negociación, resaltando dentro de estas las relacionadas con la fiscalidad.

\section{B. Modelos de negocio y de ingreso en la Economía digital}

Los nuevos modelos de negocio y de ingresos parten de las definiciones dadas por la Organización para la Cooperación y el Desarrollo Económicos (en adelante OCDE) en la Acción 1 BEPS (Proyecto OCDE/G20 de Erosión de la base imponible y traslado de beneficios - Cómo abordar los desafíos fiscales de la Economía digital), y entre los más representativos se tienen:

- Comercio electrónico. "Compra venta de bienes y servicios realizada a través de redes informáticas, mediante modelos específicamente diseñados con el objeto de recibir y hacer pedidos, sin que necesariamente el pago y la entrega se realicen por esta vía" (OCDE, 2014, p. 82).

- Servicios de pago. Intermediarios que "facilitan un medio seguro para efectuar pagos en línea [:] en las transacciones realizadas por comprador y vendedor a través de la web. Este servicio consiste en aceptar el pago desde cualquier medio de pago, procesar dicho pago y depositar el pago al vendedor, [:] evitando que los intervinientes en la transacción deban intercambiar información financiera" (OCDE, 2014, p. 86).

- Tiendas de aplicaciones. "Plataformas de distribución de programas informáticos, suministrados como complemento a un sistema operativo" (OCDE, 2014, p. 87).

- Publicidad en línea. Intermediarios que "utilizan internet para dirigirse a los clientes y hacerles llegar publicidad" (OCDE, 2014, p. 88).

- Computación en la nube. Proveedores de "servicios informáticos en línea normalizados, configurables y a la carta, como: el procesamiento, almacenamiento, software y gestión de datos, utilizando para tal fin recursos físicos y virtuales compartidos" (OCDE, 2014, p. 89).

- Negociación de alta frecuencia. Intermediarios del mercado financiero que utilizan 
herramientas tecnológicas basadas en algoritmos para obtener y analizar la información de mercados financieros, e intercambiar valores financieros a gran velocidad (OCDE, 2014).

- Plataformas participativas en red. "Intermediario que permite a los usuarios colaborar y contribuir al desarrollo, expansión, evaluación, critica y distribución de CGU contenidos generados por usuarios" (OCDE, 2014, p. 93).

De esta misma forma, el desarrollo de estos modelos de negocio a través de la economía digital ha suscitado nuevas formas de ingresos, entra las que se pueden mencionar:

- Ingresos publicitarios. Este modelo genera los ingresos a partir de la "visualización obligatoria de anuncios, (...) difusión de anuncios (...) y creación de comunidades para monetizar su audiencia" (OCDE, 2014, p. 93). Se centra básicamente en la monetización del usuario web.

- Adquisición o arrendamiento de contenido web. En este modelo, el ingreso se genera cuando el usuario paga por la descarga o visualización de contenido digital (OCDE, 2014).

- Venta de artículos. El modelo de venta de artículos genera sus ingresos a partir de la comercialización de bienes tangibles e intangibles (OCDE, 2014).

- Venta de servicios. El ingreso generado en este modelo surge a partir de servicios prestados en línea que son pagados en el momento de su prestación (OCDE, 2014).

- Ingresos por suscripción de abonos. La suscripción de abonos es un modelo de in- gresos que genera rentas por pagos anualizados, mensualizados o regulares por acceso a contenidos, servicios o suministros exclusivos a través de la web (OCDE, 2014).

- Concesión de licencias sobre contenidos y tecnología. Este modelo de ingresos consiste en el cobro de unos derechos por el "acceso a contenido digital especializado (...) y software" (OCDE, 2014, p. 94).

- Venta de datos de usuarios y estudios de mercado personalizados. En el modelo de venta de datos y estudios de mercado, el ingreso proviene de la información recabada, almacenada y analizada a través de plataformas digitales, que posteriormente se comercializa (OCDE, 2014).

- Gastos encubiertos y productos reclamo. Es un modelo de ingresos sombra, el cual no se cobra directamente al consumidor, sino que se obtiene el ingreso del sobrecosto cobrado por otros productos o servicios (OCDE, 2014).

Para el desarrollo de la investigación plasmada en este documento, es necesario profundizar en los siguientes modelos de negocios y modelos de ingresos desarrollados en la Economía digital.

\section{Comercio electrónico}

El comercio electrónico, como ya se mencionó, es un modelo de negocio de la Economía digital, en el cual, como lo menciona Davara, se ejecuta "toda aquella actividad que tiene por objeto o finalidad el intercambio de bienes o la prestación de servicios que se realiza por medio de herramientas electrónicas, (...) facilitando 
así la actividad económica comercial brindándole oportunidades para aprovechar la globalización de los mercados y haciéndolos altamente competitivos"4 (como se cita en Nieto, 2009, p. 2).

Según la legislación colombiana, el comercio electrónico se define como:

Las cuestiones suscitadas por toda relación de índole comercial, sea o no contractual estructurada a partir de la utilización de uno o más mensajes de datos o de cualquier otro medio similar. Las relaciones de índole comercial comprenden, sin limitarse a ellas, las siguientes operaciones: toda operación comercial de suministro o intercambio de bienes o servicios; todo acuerdo de distribución; toda operación de representación o mandato comercial; todo tipo de operaciones financieras, bursátiles y de seguros; de construcción de obras; de consultoría; de ingeniería; de concesión de licencias; todo acuerdo de concesión o explotación de un servicio público; de empresa conjunta y otras formas de cooperación industrial o comercial; de transporte de mercancías o de pasajeros por vía aérea, marítima y férrea, $o$ por carretera (Artículo 2, Ley 527 de 1999).

El comercio electrónico se reviste de unas características propias, como son (Nieto, 2009):

- Utilización de medios electrónicos, característica principal que lo diferencia del comercio convencional.
- Reducción de los costos de transacción gracias al uso de la tecnología y las redes de comunicación, que permiten acceder a múltiples ofertas en un solo lugar, en un horario flexible y entregas inmediatas, disminuyendo los desplazamientos, el tiempo y costo de entrega.

- Transacciones a través de un mercado virtual, que permite la realización de transacciones en cualquier lugar y momento, que las revisten del fenómeno de desgeografización.

- Inseguridad jurídica en las transacciones realizadas.

- Desintermediación, transacciones realizadas directamente entre proveedor y consumidor final.

- Ofertas personalizadas al cliente, que le proporcionan productos que satisfacen sus necesidades y hábitos de compra.

Dentro de los actores económicos que intervienen en el comercio electrónico, se pueden citar:

- Empresarios (business). "Personas físicas o jurídicas que desarrollan actividades económicas como el intercambio de bienes o la prestación de servicios" (Nieto, 2009,6), que para el caso del comercio electrónico no requieren de presencia física; solo basta con poseer un acceso por medios electrónicos o un sitio electrónico, es decir, presencia vir-

\footnotetext{
${ }^{4}$ Davara \& Davara Asesores Jurídicos, Microsoft b Central Factbook: Comercio Electrónico, Aranzadi. Elcano, Navarra 2001, p. 45. Adicionalmente, establece que no se trata únicamente de compras realizadas por Internet, sino que puede ser cualquier tipo de intercambio de información, ofertas, publicidad o anuncios, sin que sea necesario que se realice la transacción en su totalidad.
} 
tual en las redes de comunicación (Internet) (Nieto, 2009).

- Consumidores (consumer). "Destinatario final en el mercado, (...) aquel que adquiere los bienes y servicios para consumirlos o utilizarlos" (Nieto, 2009, p. 7).

- Gobierno (government). "Todos los órganos e instituciones del estado (...) que tienen presencia en el entorno electrónico" (Nieto, 2009, p. 8).

De la interacción de estos actores se sirve el comercio electrónico para desarrollarse, generando diferentes modelos de transacciones, que se pueden clasificar así:

- Según la participación de los actores:

- Comercio entre empresas (B2B). Son las transacciones dadas entre empresas, las cuales dieron origen al comercio electrónico con la utilización de transferencias de datos (EDI). Este tipo de transacciones es "más ágil, (...) [:] generalmente son de gran escala, es decir, se transan grandes volúmenes del orden mayorista" (Nieto, 2009, 9), están reguladas por el ordenamiento jurídico civil y comercial (Nieto, 2009), así como por el Derecho internacional privado, como de las reglas uniformes, especialmente las contenidas en la Convención de Naciones Unidas sobre Contratos de Compraventa Internacional de Mercadería en lo que respecta a las transacciones de índole internacional (Oviedo, 2012, p. 120).

- Comercio entre empresas y consumidores (B2C). "Son las transacciones dadas entre las empresas y el consumidor final" (Nieto, 2009, 9). Estas transacciones son del orden minorista, condensan un gran volumen de transacciones, están reguladas por el ordenamiento jurídico comercial y civil, así como el que respecta a la protección del consumidor (Nieto, 2009).

- Comercio entre empresas y gobierno (B2G). Son las transacciones dadas entre las empresas y el Estado, cuando las "empresas actúan como proveedores del Estado" (Nieto, 2009,9). Estas transacciones son de índole mayorista y están reguladas por el ordenamiento jurídico de contratación estatal.

- Comercio entre consumidores (C2C). Son las transacciones dadas entre consumidores finales cuando realizan intercambio de bienes, servicios e información, no requieren de intermediarios y se ejecutan a través de plataformas virtuales de subastas (Nieto, 2009).

- Comercio entre gobierno y consumidor (C2G). Son las transacciones dadas entre el gobierno y el consumidor final, en las que el gobierno se convierte en proveedor de servicios digitales para el consumidor final, dotándolo de mayor eficiencia en la prestación de sus servicios, y están regulados por la constitución política (Nieto, 2009).

- Comercio entre gobierno y gobierno (G2G). Son las transacciones dadas entre entidades del gobierno, fundadas en el intercambio de información y los servicios prestados interinstitucionalmente. Se regulan por la legislación aplicable para cada entidad y por los acuerdos de intercambio de información cuando se trata de transacciones del orden internacional (Nieto, 2009). 
- Según el medio utilizado:

- Comercio electrónico directo o comercio electrónico online. Son las transacciones realizadas cien por cien $(100 \%)$ a través de medios electrónicos, en las cuales el pedido, el pago y la entrega se realizan por canales virtuales, el bien o servicio no posee soporte físico, es intangible (Nieto, 2009).

- Comercio electrónico indirecto o comercio electrónico offline. Son las transacciones realizadas virtual y físicamente, parte de la transacción se realiza por medios electrónicos y se termina de forma física, el bien o servicio posee soporte físico y requiere su entrega final de forma material (Nieto, 2009).

- Según el entorno tecnológico en el que se transan:

- Comercio electrónico abierto. Son las transacciones realizadas en redes a las que puede acceder cualquier usuario sin autenticación previa, que no requie- re de habilitación contractual (Nieto, 2009).

- Comercio electrónico cerrado. Son las transacciones realizadas en redes, a las que para acceder se requiere de una autenticación previa, otorgada previa una habilitación contractual (Nieto, 2009).

El comercio electrónico, en los últimos años, ha experimentado gran auge, como se observa en la siguiente gráfica (ecommerce platforms, 2015), en la cual se indica claramente que Estados Unidos incrementó cuatro veces su tasa de ventas al por menor a través de comercio electrónico, mientras que China registra un crecimiento del $51 \%$ en el año 2013.

De igual forma, enseña la proyección del crecimiento promedio de las ventas a través del comercio electrónico para el quinquenio 2012-2017, mostrando un crecimiento promedio del $57 \%$ de las ventas en China y un $29,5 \%$ en India, lo cual resulta concordante con el nivel de penetración de internet registrado en Asia, que, para el año 2014, asciende al 45,7 \% (Internet World Stats, 2014).

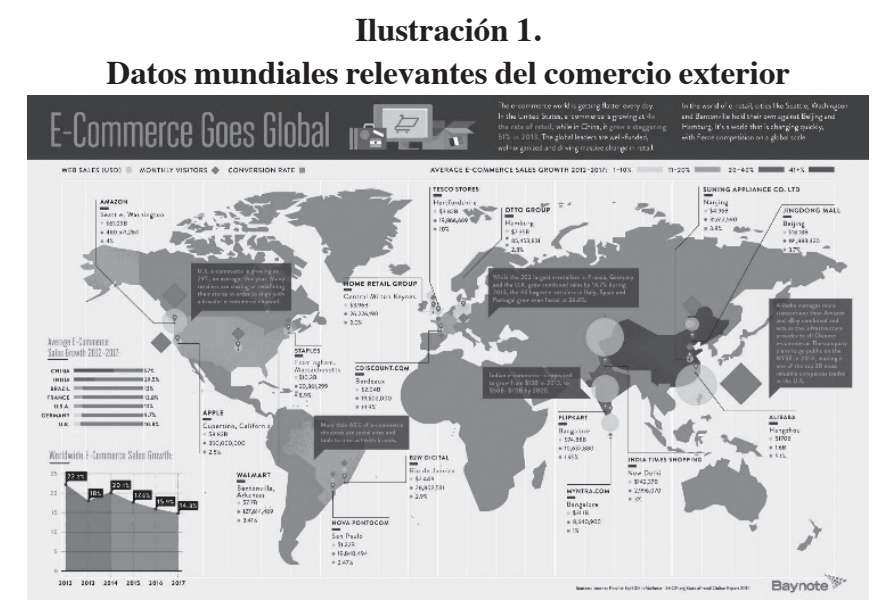

Fuente: http://ecommerce-platforms.com/ecommerce-news/e-commerce-goes-global-an-infographic 
Ilustración 2.

Penetración de internet en el mundo

Internet Users in the World Distribution by World Regions - 2014 Q2

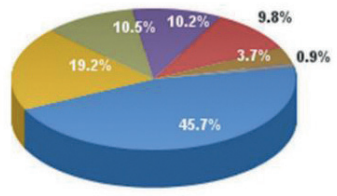

Asia $45.7 \%$

Europe $19.2 \%$

Lat Am / Carib. 10.5\%

Worth America 10.2\%

Africa $\mathbf{9 . 8 \%}$

Middle East $3.7 \%$

Oceania / Australia $0.9 \%$

Sourse:Inernet World Stats - www.internetworldstats. com/stats.htm

Basis 3,035,749,340 Internet users on June 30, 2014

Copyright 2014, Winiwatts Marketing Group
Así mismo, permite visualizar la proyección del crecimiento de las ventas a través del comercio electrónico para el quinquenio 2012-2017, respecto a lo cual se observa una tendencia a la disminución, pues pasa de un crecimiento del $22,2 \%$ en 2012 a un $14,8 \%$ en 2017 , lo cual obedece al desaceleramiento del crecimiento de los usuarios de internet que, durante los años 2014 y 2015, presenta un crecimiento del nueve por ciento (9\%), en contraste con el quince por ciento $(15 \%)$ registrado en el año 2009 (KPCB, 2016).

En la gráfica de e-Commerce Global Goes, se listan las principales empresas que concentran el comercio electrónico a nivel mundial, entre las que se hallan:

Principales compañías de comercio electrónico en el mundo

\begin{tabular}{|l|c|c|c|}
\hline \multicolumn{1}{|c|}{ Empresa } & $\begin{array}{c}\text { Continente de } \\
\text { ubicación }\end{array}$ & $\begin{array}{c}\text { Ventas web en 2014 } \\
\text { (billones de dólares) }\end{array}$ & $\begin{array}{c}\text { Visitas mensuales } \\
\text { en 2014 }\end{array}$ \\
\hline Amazon & Norteamérica & 61,09 & 480.571 .284 \\
\hline Apple & Norteamérica & 8,83 & 350.000 .000 \\
\hline Stapless & Norteamérica & 10,30 & 20.861 .299 \\
\hline Walmart & Norteamérica & 7,70 & 127.614 .469 \\
\hline Nova Pontocom & Suramérica & 1,22 & 19.840 .494 \\
\hline B2w Digital & Suramérica & 2,44 & 28.802 .531 \\
\hline Home Retail Group & Europa & 3,96 & 26.226 .190 \\
\hline Teco Stores & Europa & 3,82 & 19.866 .669 \\
\hline Otto Group & Europa & 7,35 & 85.453 .831 \\
\hline Cdiscount.com & Europa & 2,04 & 19.602 .000 \\
\hline Flipkart & Asia & 74,88 & 10.637 .000 \\
\hline Myntra.com & Asia & 31,10 & 8.640 .900 \\
\hline India Time Shopping & Asia & 142,37 & 2.996 .070 \\
\hline Suning Appliance Co. Ltd. & Asia & 4,96 & 31.612 .590 \\
\hline Jingdong Mall & Asia & 18,18 & 191.883 .420 \\
\hline Alibaba & Asia & 170,00 & 1.600 .000 .000 \\
\hline
\end{tabular}

Fuente: Creación propia a partir de los datos de E-Commerce Goes Global 


\section{Ilustración 3. \\ Crecimiento del internet en el mundo}

Global Internet Users, 2008-2015

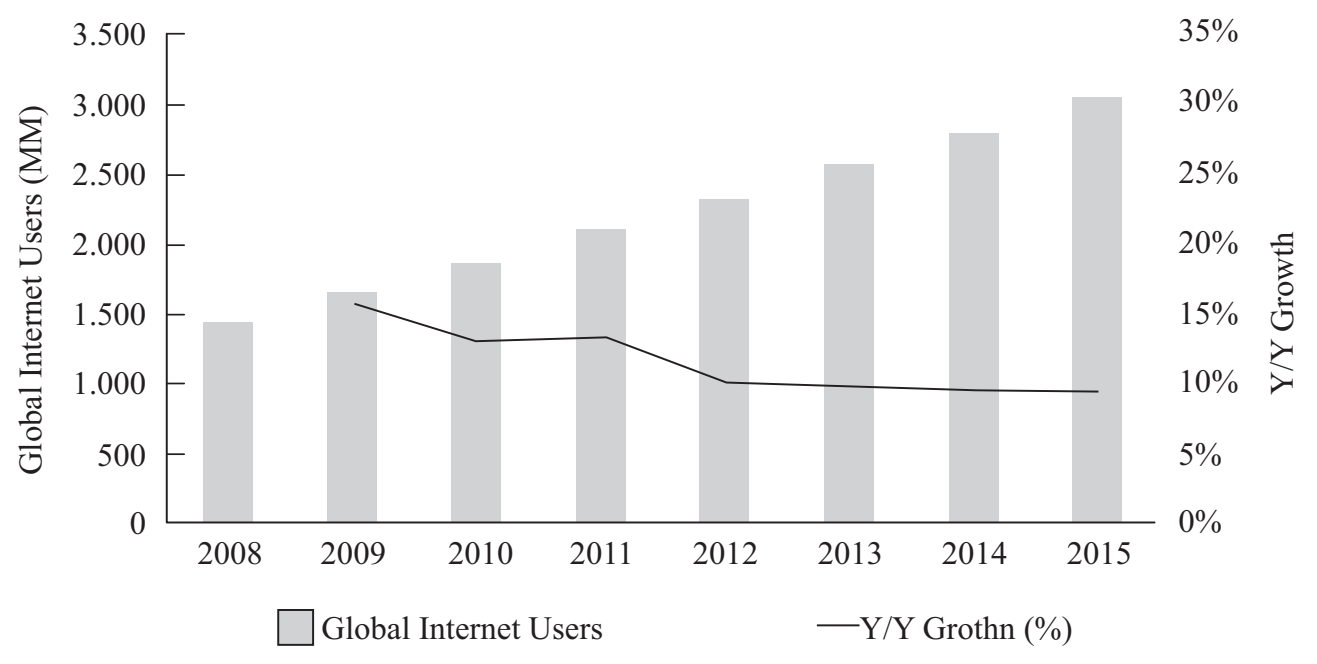

Fuente: http://www.kpcb.com/blog/2016-internet-trends-report

$\mathrm{Al}$ respecto, se puede observar que el mayor volumen de ventas a través del comercio electrónico se concentra en Asia, con un valor de total de ventas en el año 2014 de 441,49 billones de dólares, concentradas en seis compañías, seguido por Norteamérica, que tuvo ventas a través del comercio electrónico en este periodo por valor de 87,92 billones de dólares, concentradas en cuatro compañías.

Europa, por su parte, aportó a las ventas a través del comercio electrónico 17,7 billones de dólares con una participación de cuatro compañías y, por último, se sitúa Suramérica, que concentró ventas a través del comercio electrónico por valor de 3,66 billones de dólares y una representación de dos compañías.

Colombia no ha sido ajeno a la evolución y crecimiento del comercio electrónico, de acuerdo con las estadísticas registradas por la Cámara Colombiana de Comercio Electrónico (2016) que se presentan en el siguiente gráfico, en las cuales se puede observar que el valor transado a través del comercio electrónico ha registrado un crecimiento significativo del sesenta y cuatro por ciento (64\%) en el periodo 2013 a 2015, alcanzando una participación del cuatro punto cero ocho por ciento $(4,08 \%)$ en el PIB, equivalente a 400.388 millones de dólares. Dentro de las categorías de distribución más representativas en el comercio electrónico, hallamos el gobierno, con una participación del dieciocho por ciento (18\%), seguido por el sector financiero, que tuvo una participación del diecisiete por ciento $(17 \%) \mathrm{y}$, en un tercer lugar, se encuentra el sector de las tecnologías y comunicaciones, con una participación del quince por ciento $(15 \%)$. 
Estadísticas Comercio Electrónico en

Colombia 2014

\section{$3^{\text {ER }}$ ESTUDIO DE TRANSACCIONES NO PRESENCIALES DE QCOMMERCE
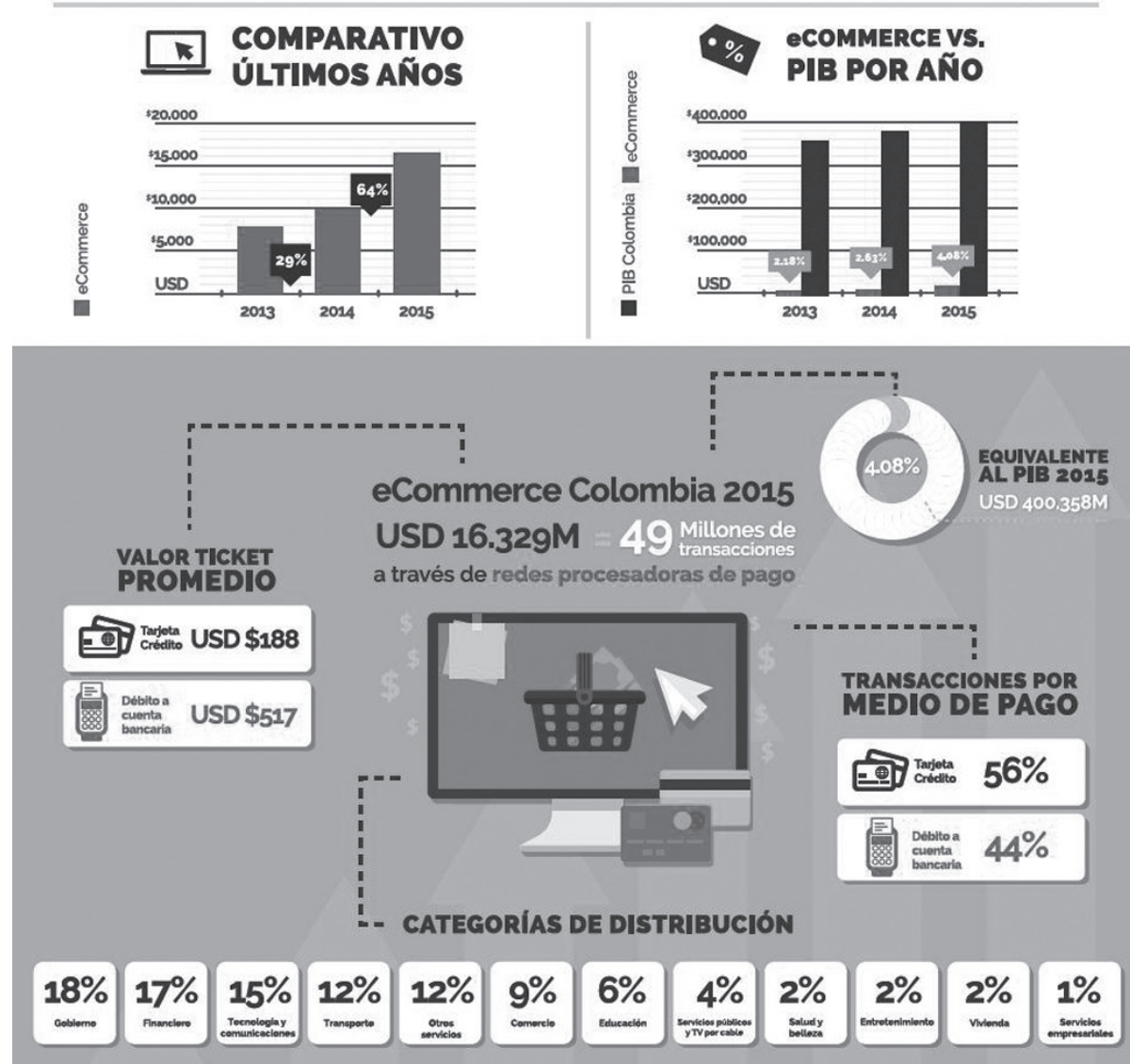

\section{COMPARATIVO VALOR TRANSACCIONES POR MEDIO DE PAGO 2015}

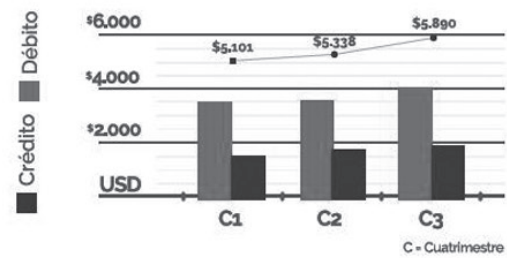

(\$) USD \$6.368M* A TRAVÉS DE PASARELAS DE PAGO

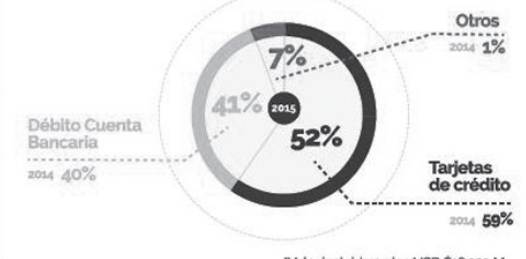

Valor incluido en los USD $\$ 16.329 \mathrm{M}$

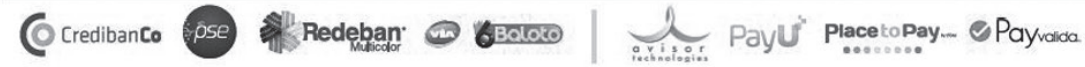

$\begin{array}{ll}\text { WWW.ccce.org.co } & \text { Información con base a las clifras consolidadas entre el } 1 \text { de enero y el } 31 \text { de } \\ \text { diciembre de 2015. TRM constante de \$2000.33. Fuente PIB: Banco de la República. }\end{array}$
} 
2. Concesión de licencias sobre contenidos y tecnologías

Este modelo de ingresos se basa en los pagos aplicables a los acuerdos de licencia, los cuales pueden ser sumas globales o regalías; con este modelo de ingresos, el consumidor paga un derecho por el uso de los contenidos y/o tecnologías, sin existir transferencia de la propiedad de los mismos y sin otorgar derecho a su usufructo (Organización Mundial de la Propiedad Intelectual (en adelante OMPI), 2010).

Las modalidades de pago por el derecho de uso de contenidos y tecnologías consisten en:

- Sumas globales. Se paga una única vez a la firma del acuerdo una suma, por un periodo determinado de uso de los contenidos y/o tecnologías.

- Regalías. Son pagos mensuales realizados por el uso de los contenidos y/o tecnologías por el tiempo que dure el acuerdo de licenciamiento (OMPI, 2010).

\section{Streaming como negocio de la economía digital}

El streaming es una tecnología que permite la visualización de archivos multimedia (audio y video) directamente desde la web del proveedor del servicio sin descargarlo previamente al equipo tecnológico, que se usa para visualizarlo. Este servicio permite visualizar el contenido en la medida en que se va descargando, sin necesidad de almacenarlo en el equipo (Cehis, 2013).

El streaming es prestado por un operador propietario o licenciante de los contenidos distribuidos, que pueden estar o no alojados en su servidor o en la nube, y a los cuales el usuario accede a través de la web del operador de streaming (Cehis, 2013). Puede ser transmitido de dos formas:

- En vivo: cuando se trasmite el contenido en el mismo instante en que se realiza.

- Diferido: cuando se transmite contenido previamente grabado y alojado en un servidor.

Esta característica de la tecnología permite que el usuario pueda acceder a los contenidos multimedia distribuidos, sin importar el lugar donde se encuentre o la hora en que lo desee, y lo puede realizar desde múltiples dispositivos $^{5}$ (Montoya, 2015, párr. 7), lo cual reúne las características propias de la Economía digital.

Siendo uno de los negocios con más auge y apertura que se ha dado en el comercio electrónico, como modelo de negocio de la economía digital, el cual se podría advertir se ha desarrollado principalmente bajo el modelo de transacción B2C, en la cual el proveedor de streaming, para acceder a contenidos de video y/o audio online otorga al consumidor final la licencia para el uso y goce de su tecnología para acceder a los contenidos pre- 
cargados o transmitidos desde su sitio web, ejecutando un comercio electrónico directo u online, en el cual el consumidor recibe la oferta en línea, la acepta, inscribe su pago y recibe la membresía requerida para acceder a la tecnología que permita la visualización de los contenidos multimedia, tratándose por tanto de un comercio electrónico abierto al que puede acceder cualquier usuario.

Este negocio ciento por ciento (100\%) online del comercio electrónico se vale de la computación en la nube para desarrollarse, pues los proveedores de streaming alojan dicha tecnología y los contenidos multimedia a los cuales se puede acceder a través de esta, en servidores de proveedores de servicios de internet que proporcionan la infraestructura física, y la administración de la tecnología y los contenidos alojados, bajo contratos suscritos en la modalidad SaaS - software como servicio.

Es por ello por lo que, aunque el streaming es un negocio del comercio electrónico, está ligado a la computación en la nube, otro modelo de negocio de la economía digital, pues este es el soporte para su desarrollo.

Este se ejecuta bajo el modelo de ingresos de la Economía digital, denominado concesión de licencias sobre contenidos y tecnologías, en el cual el consumidor paga un derecho por el uso de la tecnología de streaming, que permite visualizar los contenidos multimedia online desde la web del proveedor, sin existir transferencia de la propiedad de la misma y sin otorgar derecho a usufructo, pagando una regalía como pago mensualizado por el tiempo que dure el acuerdo de licenciamiento.
Como ya se acotó, el streaming crece día a día, el consumo de contenidos multimedia de audio y video migra a pasos agigantados al streaming, dejando de adquirir la música en formatos físicos, escuchándola directamente desde la página web de los proveedores de streaming, e igualmente se ha dejado de ver la televisión análoga, trasladando el consumo a la visualización de contenidos de video online, ya que esta tecnología le permite al usuario ver y escuchar las tandas de videos y música que desea, en el momento y horario que lo pueda y quiera hacer (Montoya, 2015).

Una pequeña muestra del auge que ha tenido el streaming en el mundo son las estadísticas presentadas por elcolombiano. com; así, dentro de los principales operadores de streaming hallamos a:

- Netflix: este es el principal servicio de entretenimiento por internet en el mundo. Presente en más de 190 países, 104 millones de personas disfrutan más de 125 millones de horas de programas de TV y películas por día, incluidos los documentales, las películas y series originales de Netflix. Los miembros de Netflix pueden ver lo que quieran, cuando quieran, en casi cualquier pantalla conectada a internet, y pueden reproducir, pausar y ver un título, sin publicidad ni compromisos (Netflix. com, s.f).

- Spotify: te ofrece la música adecuada para cada momento en computadoras, teléfonos móviles, tabletas, sistemas de entretenimiento en el hogar, automóviles, consolas de juegos y más (Spotify. com, s.f.). 
- Deezer: es un sitio web que ofrece música de forma ilimitada mediante una suscripción (Deezer.com, s.f.).

- Hulu: es un servicio de transmisión premium líder, que ofrece acceso instantáneo a canales en vivo y a pedido, series y películas originales, y una biblioteca premium de TV y películas a más de 47 millones de espectadores únicos en los Estados Unidos. Desde su lanzamiento en 2008, Hulu constantemente ha estado a la vanguardia del entretenimiento y la tecnología. Hulu es el único servicio de transmisión que ofrece programas de temporada actual, tanto publicitarios como comerciales, de las redes de transmisión más grandes de los Estados Unidos; bibliotecas de exitosas series de televisión y películas; convirtiéndolo en el único servicio de TV que reúne en vivo, bajo demanda, originales y contenido de la biblioteca, todo en un solo lugar, a través de la sala de estar y los dispositivos móviles (Hulu.com, s.f.).

- iTunes: es un reproductor de medios y tienda de contenidos multimedia desarrollado por Apple con el fin de reproducir, organizar y sincronizar iPods, iPhones, iPads y comprar música (Apple.com, s.f.).

Como se puede apreciar, es un negocio ejecutado a través de la modalidad B2C del modelo de comercio electrónico, servido por la computación en la nube, que desplaza la venta de servicios de televisión analógica y música en formato físico. Ello conlleva a que se analice esta forma de hacer negocios que invade al mundo, y cómo estos tributan sobre los ingresos obtenidos, o si no lo están haciendo, cómo regular la materia.

\section{Formas contractuales de la Economía digital}

La economía digital, a pesar de la inseguridad jurídica que la reviste, cuenta con un instrumento para recubrir de naturaleza jurídica las transacciones realizadas en su ecosistema. Dicho instrumento es la denominada contratación electrónica.

La contratación electrónica, de acuerdo con lo esbozado por Villalba (2008), no es una nueva forma contractual, sino una manera distinta de celebrar contratos, manifestando el consentimiento a través de medios electrónicos, la cual es regulada a nivel internacional por medio de la Ley Modelo sobre comercio electrónico de la Comisión de las Naciones Unidas para el Derecho mercantil internacional - CNUDMI, apropiada en el ordenamiento doméstico mediante la Ley 527 de 1999, ley de comercio electrónico en Colombia.

Al respecto, esta legislación brinda reconocimiento jurídico a los mensajes de datos y determina la formación y validez de los contratos en los que el consentimiento y perfeccionamiento se realiza a través de medios virtuales. De igual forma, determina que dichos contratos son regulados por las normas aplicables al acto o negocio jurídico contenido en el mismo.

Así las cosas, encontramos que este tipo contractual se regula en una primera instancia en el Derecho internacional privado y se rige por el principio locus regit actum, "la ley del estado en el que un acto se lleva a cabo, determina la forma de este acto" (Monroy, 2013, p.337), por tanto, ello remite a que, en su forma, el contrato cumpla lo preceptuado 
en la legislación doméstica, que para el caso colombiano se halla en el Código de Comercio y el Código Civil.

Al respecto, el Código Civil, en el Artículo 21, apropia este principio, y en el libro cuarto define contrato o convención como "un pacto por el cual una parte se obliga para con otra a dar, hacer o no hacer alguna cosa" (Art. 1495, Código Civil, Ley 84 de 1873, 1873).

Por tanto, de dicha definición, se advierte que para la existencia del contrato se requiere que exista una obligación y que la misma se contraiga entre dos partes, y que dichas partes se revistan de las siguientes condiciones para que se considere válido:

- Se revista de capacidad, "que sea legalmente capaz" (Art. 1503, Código Civil, Ley 84 de 1873) para obligarse.

- Se consienta la voluntad de suscribir el acto y que el mismo se halle libre de vicio, error, fuerza o dolo (Art. 1508 al 1516, Código Civil, Ley 84 de 1873), es decir, que la voluntad de suscribir el acto sea espontáneo y libre.

- Se suscriba sobre un objeto y causa lícita, es decir, que esta no esté prohibida por las leyes y contraria a las buenas costumbres o al orden público (Art. 1517 al 1525, Código Civil, Ley 84 de 1873).

En cuanto a la normatividad prevista sobre contratos en el Código de Comercio, se advierte en el libro cuarto lo relacionado con los mismos, el cual inicia con la remisibilidad al Derecho civil respecto a los principios que gobiernan la formación de los actos y contratos, y adicionalmente fija en el Ar- tículo 824 las formalidades para obligarse, en el cual cita que los comerciantes podrán expresar su voluntad de contratar u obligarse verbalmente, por escrito o por cualquier modo equívoco (Código de Comercio, Decreto 410 de 1971).

Así mismo, determina los elementos esenciales de la oferta, identificando esta como el proyecto de negocio jurídico que una persona formula a otra, la cual debe contener los elementos esenciales del negocio y debe ser comunicada al destinatario, entendiéndose que se ha surtido dicho proceso cuando se utilice cualquier medio adecuado para hacerlo (Artículo 845, Código de Comercio, Decreto 410 de 1971). Así mismo, en el Artículo 846, evalúa la irrevocabilidad de la propuesta, determinando que el proponente no podrá retractarse y, si ello se diera, se deben indemnizar los perjuicios que cause con su revocación al destinatario (Código de Comercio, Decreto 410 de 1971).

En el Artículo 864, define lo que se considera contrato y determina que el contrato se entiende celebrado en el lugar de residencia del lugar del proponente y el momento en que este recibe la aceptación de la propuesta (Código de Comercio, Decreto 410 de 1971, 1971). De igual forma, en el Artículo 869 establece que la ejecución de contratos celebrados en el exterior con cumplimiento en Colombia se regirán por la ley colombiana.

Como se ha mencionado en los apartes anteriores, el streaming es un negocio ciento por ciento (100\%) virtual, por lo tanto, su contratación es electrónica, al ser en su mayoría los proveedores de este multinacionales ubicadas en el exterior, la contratación para los usuarios colombianos resulta 
ser no solo electrónica, sino internacional; la contratación del streaming se reviste como términos de uso y declaración de privacidad; en ellos el proveedor establece las condiciones de la prestación del streaming, la ley aplicable y las condiciones generales que revisten la negociación, los cuales se trasmiten al usuario y el mismo los acepta en el momento de suscribir la membresía, perfeccionándose en el momento de acceder al servicio y realizar el pago.

\section{Análisis de la tributación de la Economía digital, bajo la óptica de la Acción 1 BEPS}

La Economía digital, de acuerdo con lo descrito en los informes de la Acción 1 BEPS, elaborados por la Organización para la Cooperación y el Desarrollo Económico (en adelante OCDE) (2014), no es más que la inserción de la economía tradicional al uso de las tecnologías de la información y la comunicación (en adelante TIC) y las redes de comunicación, a través de las cuales se desarrollan las funciones comerciales de forma electrónica y de esta misma forma se satisfacen las necesidades. En virtud de la inserción de la economía real en las TIC, esta nueva economía se reviste de unas características específicas, como son:

- Facilita la movilidad de los actores intervinientes en ella y se basa en las transacciones de bienes intangibles, pues mediante el uso de las TIC su transmisión se realiza vía electrónica sin necesidad de soporte físico desde y hacia cualquier lugar del mundo en cualquier momento.

- Promueve la utilidad de datos trasmitidos a través de las redes, pues facilita su recopilación permitiendo acceder a información específica de cada actor y llegar de forma personalizada a cada uno de ellos.

- Genera constante evolución de los mercados, que hacen que este nuevo tipo de economía sea más volátil. $\mathrm{Al}$ estar ligada y depender de las tecnologías, su avance es constante e introduce nuevos actores día a día, así como llega a nuevos territorios gracias a la expansión global que le proporciona su intangibilidad.

- Posibilita nuevos modelos de negocios multilaterales, pues la presencia virtual a través de las redes de telecomunicaciones le proporcionan la infraestructura necesaria para realizar sus operaciones comerciales en cualquier lugar y en cualquier momento, ello aunado a la transacción de bienes intangibles que admiten la operabilidad sin necesidad de presencia física de los autores.

- Origina tendencias hacia el oligopolio y monopolio del mercado de las tecnologías de comunicación e información, pues la alta demanda requiere de especialidad y grandes inversiones de capital (OCDE, 2014).

Así mismo, trae consigo estrategias de planificación fiscal que buscan la erosión de las bases fiscales. En el análisis realizado en la Acción 1 BEPS, la OCDE ha agrupado dichas estrategias así:

\section{Impuestos directos:}

- Minimización de la carga tributaria en el Estado de la fuente, evitando toda presencia fiscalmente imponible 
o, en caso de tener una presencia fiscalmente imponible, traslado de los beneficios brutos mediante estructuras comerciales o reducción del beneficio neto, maximizando las deducciones a nivel del ordenante.

- Escasa o nula retención en la fuente.

- Escasa o nula tributación a nivel del perceptor de las rentas (posible a través de países o territorios de baja tributación, regímenes preferenciales o mecanismos híbridos), con derecho a sustanciosos beneficios excepcionales, frecuentemente sustentados en acuerdos intragrupo.

- No imposición de los rendimientos sometidos a baja tributación a nivel de la matriz.

\section{Impuestos indirectos}

- Suministros digitales a distancia a empresas exentas.

- Suministros digitales a distancia a empresas con establecimientos (sucursales) en más de una jurisdicción (EML), que se dedican a actividades exentas.

Las características específicas que revisten la Economía digital implican grandes desafíos, sin ser ajeno a ello el marco fiscal, aunado a las estrategias de planificación fiscal desarrolladas en esta nueva forma de negociar, han llevado a que los Estados evalúen y se cuestionen cómo abordar esta nueva forma de hacer negocios desde el punto de vista de la fiscalidad. Es por esto que la OCDE (2014), en el planteamiento de la Acción 1 BEPS - Abordar los retos de la Economía digital para la imposición, se ha cuestionado: “¿El marco fiscal internacional vigente puede dar respuesta a los cambios motivados por la economía digital y los modelos de negocios que dicho marco posibilita para asegurar que los beneficios tributen en la jurisdicción en que se desarrollan las actividades económicas y allí donde se genera valor?" (OCDE, 2014, p. 22).

\section{A. Premisas en materia fiscal que enmarcan la tributación en la economía digital}

El anterior cuestionamiento ha sido apropiado por los diferentes países miembros y no miembros de la OCDE que se encuentran sumergidos en la globalización de la economía y no ajenos al fenómeno de Economía digital, determinando a partir del análisis de las características propias de este nuevo modelo económico tres grandes premisas en materia fiscal:

- La recopilación de datos de identificación de los actores que intervienen en la Economía digital.

- La determinación de un criterio de sujeción que permita establecer la jurisdicción que ejerce la potestad tributaria para gravar los beneficios que genera este modelo económico.

- La calificación de las rentas a efectos de imposición directa que facilite la determinación de la potestad tributaria de gravar dichas rentas (OCDE, 2014).

\section{B. Desafios en materia fiscal que trae la Economía digital}

Premisas que circunscriben algunos desafíos fiscales, en materia de impuestos directos:

\section{(1)}


- “Atribución y reparto de la soberanía tributaria entre distintas jurisdicciones.

- "Criterio utilizado para determinar dónde se realizan las actividades económicas y dónde se genera valor a efectos tributarios" (OCDE, 2014, p. 138).

- Adecuada calificación y clasificación de los pagos efectuados en el contexto de los nuevos modelos de negocio de la economía digital.

Y respecto a los impuestos indirectos:

- "Exenciones en la importación de escaso valor.

- "Aumento de los suministros trasnacionales de bienes intangibles y servicios destinados al consumidor final" (OCDE, 2014, 147, p. 149).

\section{Recomendaciones para abordar los desafios en materia fiscal que trae la Economía digital}

Los anteriores desafíos deben ser analizados a partir de:

- "La relación de la economía digital con los conceptos de fuente y residencia para caracterización de los ingresos para fines impositivos.

- "Modo en que las empresas de la economía digital añaden valor y obtienen beneficios" (OCDE, 2014, p. 29).

Entre las recomendaciones dadas por la OCDE para abordar estos desafíos, se hallan:

\section{Respecto a la fiscalidad directa:}

- Modificaciones de las excepciones al estatus de establecimiento permanen- te, mediante las cuales se supriman o modifiquen algunas actividades catalogadas como preparatorias bajo el concepto de la economía tradicional y que hoy por hoy, en el marco de la economía digital, se han convertido en funciones esenciales.

- Un nuevo nexo con base en una presencia virtual significativa para aquellas actividades digitales totalmente desmaterializadas, cuyo ejercicio se realice exclusivamente de forma digital y que no precisa, o lo hace mínimamente, de elementos físicos en el Estado de fuente, ligando dicha presencia virtualmente significativa a ciertos umbrales indicativos de una interacción sustancial y continuada con la economía del país fuente.

- Sustitución del concepto de establecimiento permanente versus presencia virtual significativa, a fin de ajustar el contexto digital en que se desarrollan las transacciones en la Economía digital que no requieren de presencia física alguna o mínima en ninguna jurisdicción.

- Sometimiento de las transacciones digitales a una retención en la fuente a través de las instituciones financieras involucradas en dichos pagos.

- Introducción del impuesto sobre las transacciones electrónicas o bit tax, el cual recaería sobre la utilización de banda ancha.

Respecto a la fiscalidad indirecta:

- Revisión de los umbrales de exención para importaciones de bienes de escaso valor, los cuales en muchas jurisdicciones se establecieron dentro del 
contexto de la economía tradicional, implementando mecanismos simplificados que faciliten la contribución y sirvan de herramienta de control para las administraciones tributarias.

- Obligar a los proveedores no residentes a inscribirse en los regímenes de impuestos indirectos y declarar el impuesto correspondiente, implementando mecanismos simplificados que faciliten la contribución y sirvan de herramienta de control para las administraciones tributarias (OCDE, 2014, pp. 156-162).

\section{Impuesto de renta en la Economía digital para sociedades extranjeras no residentes que operan streaming en Colombia}

\section{A. Sujetos pasivos}

Como sujetos pasivos del impuesto sobre la renta en Colombia, se pueden citar, entre otros, las personas naturales, las sucesiones ilíquidas, las sociedades y entidades; respecto a este último sujeto pasivo, el Artículo 12 del Estatuto Tributario esboza:

Artículo 12. [Creado por el Art. 13 del D.L. 2053 de 1974] Sociedades y Entidades sometidas al impuesto. Las sociedades y entidades nacionales son gravadas, tanto sobre sus rentas y ganancias ocasionales de fuente nacional como sobre las que se originen de fuentes fuera de Colombia.
Las sociedades y entidades extranjeras son gravadas únicamente sobre sus rentas y ganancias ocasionales de fuente nacional (destacado fuera de texto).

Así mismo, el Artículo 20 del Estatuto Tributario ${ }^{6}$ indica que

Artículo 20. [Creado por el Art. 6 del D.L. 2053 de 1974 y el Art. 13 del D. 231 de 1983] Las sociedades y entidades extranjeras son contribuyentes. [Modificado por el Art. 85 de la L. 1607 de 2012] Salvo las excepciones previstas en los tratados internacionales y en el derecho interno, son contribuyentes del impuesto sobre la renta y complementarios las sociedades y entidades extranjeras de cualquier naturaleza, únicamente en relación con sus rentas y ganancias ocasionales de fuente nacional, independientemente de que perciban dichas rentas y ganancias ocasionales directamente o a través de sucursales o establecimientos permanentes ubicados en el país. Para tales efectos, se aplica el régimen consagrado para las sociedades anónimas nacionales, salvo cuando tenga restricciones expresas.

Determinando que se entiende como sociedad extranjera en el Artículo 21 del Estatuto Tributario ${ }^{7}$ lo siguiente:

Artículo 21. [Creado por el Inc. 2 del Art. 6 del D.L. 2053 de 1974] Concepto de sociedad extranjera. [Modificado por el Art. 88 de la L. 1607 de 2012] Se consideran extran- 
jeras las sociedades $u$ otras entidades que no sean sociedades o entidades nacionales.

De lo cual se puede advertir que Colombia, en ejercicio de su soberanía y jurisdicción, teniendo en cuenta la aplicación de la norma tributaria en todo el territorio del Estado colombiano (Muñoz y Zornoza, 2015, pp. 207-270), para el impuesto de renta, aplica como criterio de sujeción el principio de residencia y el principio de fuente, según la calidad del sujeto pasivo, así:

- Residentes fiscales: principio de residencia (renta mundial)

- No residentes: principio de fuente (territorialidad)

\section{B. Hecho generador}

En Colombia, el impuesto de renta y complementarios se constituye como una obligación sustancial, y se origina en el momento de cumplirse los presupuestos del hecho generador.

El hecho generador del impuesto de renta y complementarios es la percepción de ingresos en el periodo gravable susceptibles de producir un incremento en el patrimonio en el momento de su percepción, que no hayan sido expresamente exceptuados (Decreto 624, 1989, Art. 26).

Al respecto, la legislación tributaria indica los ingresos que se consideran de fuente nacional y los que no son considerados co- mo tales, enumerando en el Artículo 24 del Estatuto Tributario ${ }^{8}$ como ingresos de fuente nacional los siguientes:

Artículo 24. [Creado por el Art. 14 del D.L. 2053 de 1974; Art. 12, 14 y 15 de la L. 75 de 1986] Ingresos de fuente nacional. [Inc. 1 modificado por el Art. 66 de la L. 223 de 1995] Se consideran ingresos de fuente nacional los provenientes de la explotación de bienes materiales e inmateriales dentro del país y la prestación de servicios dentro de su territorio, de manera permanente o transitoria, con o sin establecimiento propio. También constituyen ingresos de fuente nacional los obtenidos en la enajenación de bienes materiales e inmateriales, a cualquier título, que se encuentren dentro del país al momento de su enajenación. Los ingresos de fuente nacional incluyen, entre otros, los siguientes:

1. Las rentas de capital provenientes de bienes inmuebles ubicados en el país, tales como arrendamientos o censos.

2. Las utilidades provenientes de la enajenación de bienes inmuebles ubicados en el país.

3. Las provenientes de bienes muebles que se exploten en el país.

4. Los intereses producidos por créditos poseídos en el país o vinculados económicamente a él. Se exceptúan los intereses provenientes de créditos transitorios originados en la importación de mercancías y en sobregiros o descubiertos bancarios. 
5. Las rentas de trabajo tales como sueldos, comisiones, honorarios, compensaciones por actividades culturales, artísticas, deportivas y similares o por la prestación de servicios por personas jurídicas, cuando el trabajo o la actividad se desarrollen dentro del país.

6. Las compensaciones por servicios personales pagados por el Estado colombiano, cualquiera que sea el lugar donde se hayan prestado.

7. Los beneficios o regalías de cualquier naturaleza provenientes de la explotación de toda especie de propiedad industrial, o del "Know how", o de la prestación de servicios de asistencia técnica, sea que éstos se suministren desde el exterior o en el país.

Igualmente, los beneficios o regalías provenientes de la propiedad literaria, artística y científica explotada en el país.

8. La prestación de servicios técnicos, sea que estos se suministren desde el exterior o en el país.

9. Los dividendos o participaciones provenientes de sociedades colombianas domiciliadas en el país.

10. Los dividendos o participaciones de colombianos residentes, que provengan de sociedades o entidades extranjeras que, directamente o por conducto de otras, tengan negocios o inversiones en Colombia.

11. Los ingresos originados en el contrato de renta vitalicia (1), si los beneficiarios son residentes en el país o si el precio de la renta está vinculado económicamente al país.

12. Las utilidades provenientes de explotación de fincas, minas, depósitos naturales y bosques, ubicados dentro del territorio nacional.

13. Las utilidades provenientes de la fabricación o transformación industrial de mercancías o materias primas dentro del país, cualquiera que sea el lugar de venta o enajenación.

14. Las rentas obtenidas en el ejercicio de actividades comerciales dentro del país.

15. Para el contratista, el valor total del respectivo contrato, en el caso de los denominados contratos "llave en mano" y demás contratos de confección de obra material.

16. [Adicionado por el Art. 24 de la L. 1819 de 2016] Las primas de reaseguros cedidas por parte de entidades aseguradoras colombianas a entidades del exterior.

Parágrafo. Lo dispuesto en los numerales 8 y 15 se aplicará únicamente a los contratos que se celebren, modifiquen o prorroguen a partir del 24 de diciembre de 1986. En lo relativo a las modificaciones o prórrogas de contratos celebrados con anterioridad a esa fecha, las disposiciones de tales numerales se aplicarán únicamente sobre los valores que se deriven de dichas modificaciones o prórrogas (destacado fuera de texto).

Teniendo en cuenta lo esbozado anteriormente, se analiza la posible clasificación como ingresos de fuente nacional de los ingresos percibidos por las sociedades extranjeras no residentes en Colombia que proveen streaming en el territorio nacional, a fin de determinar si las mismas resultan ser contribuyentes del impuesto de renta en Colombia de acuerdo con el principio 
de territorialidad aplicado para las sociedades extranjeras no residentes, respecto a lo cual se advierte que, según lo previsto por el Estado colombiano en su legislación doméstica, en la que ha definido en el Artículo 24 del Estatuto Tributario ${ }^{9}$ qué ingresos se consideran de fuente nacional, enumerando entre estos en el numeral 7 de dicho artículo: "Los beneficios o regalías de cualquier naturaleza provenientes de la explotación de toda especie de propiedad industrial ...", categorización esta en la cual encajan las rentas obtenidas por las sociedades extranjeras no residentes en Colombia que proveen streaming en el territorio nacional.

Esta clasificación se determina a partir del análisis de la definición de streaming y de las formas contractuales con las cuales se pone a disposición esta tecnología en los usuarios que la suscriben; como ya se mencionó en el capítulo I de la presente investigación, streaming es "la tecnología que se utiliza para optimizar la descarga y reproducción de archivos de audio y video, que suele tener un cierto peso, ya que en internet es necesario descargar previamente el archivo desde el servidor remoto al cliente local para luego visualizarlo en la pantalla de este último".

El streaming funciona de la siguiente manera:

- Conexión con el servidor: el reproductor cliente conecta con el servidor remoto y este comienza a enviarle el archivo.
- Buffer: el cliente comienza a recibir el fichero y construye un buffer o almacén donde empieza a guardarlo.

- Inicio de la reproducción: cuando el buffer se ha llenado con una pequeña fracción inicial del archivo original, el reproductor cliente comienza a mostrarlo mientras continúa en segundo plano con el resto de la descarga (Ministerio de Educación, Política Social y Deporte de España, 2008).

Identificando en esta definición una primera condición que permite la clasificación de la renta obtenida por las sociedades extranjeras no residentes en Colombia que proveen streaming en el territorio nacional, como un beneficio o regalía de cualquier naturaleza proveniente de la explotación de una especie de propiedad industrial en el país, pues es claro en esta definición y en la descripción de cómo es su funcionamiento que el streaming es una tecnología que utiliza para su funcionamiento diferentes hardware (servidor y dispositivos de reproducción) y software (software y buffer).

Ahora bien, teniendo en cuenta la definición de tecnología dada por la Real Academia de la Lengua Española como "conjunto de teorías y de técnicas que permiten el aprovechamiento practico del conocimiento científico y/o conjunto de instrumentos y procedimientos industriales de un determinado sector o producto", se puede señalar que al suscribir los contratos de acceso a la tecnología de streaming se suscribe 
un acuerdo de licenciamiento del título de propiedad industrial que posee la sociedad extranjera no residente en Colombia sobre esta tecnología.

Lo anterior se puede corroborar con la lectura y análisis realizada a los términos de uso ${ }^{10}$ aceptados en el momento de la suscripción de streaming con los proveedores de esta tecnología, pues en estos se indica claramente que:

- Se otorga una licencia limitada

- El acceso a los contenidos se realiza a través de un software desarrollado por los proveedores de streaming

- No se transfiere ningún derecho o título

- Las condiciones de uso

- El periodo de suscripción

Esto se ajusta a las características previstas por la OMPI ${ }^{11}$ en su definición de Licencia de títulos de propiedad intelectual, en la que indica que "las licencias son asociaciones entre un titular de derechos de propiedad intelectual o también llamado licenciante y otra persona que recibe la autorización para usar dichos derechos o también llamado licenciado, a cambio de un pago convenido de antemano (tasa o regalía) ... es la autorización que el titular del derecho de propiedad intelectual otorga a un tercero para utilizarla en los términos y condiciones acordadas, con una finali- dad determinada, en un territorio definido y durante un periodo de tiempo convenido".

Ahora bien, de acuerdo con lo descrito anteriormente, se deja claro que el streaming de audio y video que proveen las sociedades extranjeras en Colombia no es un servicio de telecomunicaciones, y para el caso específico de streaming de contenido multimedia de video, no es un servicio de televisión, ya que servicio de televisión se define como "Servicio de telecomunicaciones que ofrece programación dirigida al público en general o una parte de él que consiste en la emisión, transmisión, difusión, distribución y recepción de señales de audio y video y es considerada en la constitución del país, como un servicio de carácter público" (ANTV - Autoridad Nacional de Televisión, s.f.) y las fases que lo constituyen según la definición dada por la Real Academia de la Lengua Española comprenden:

- Emitir: transmitir algo por medio de ondas electromagnéticas (ondas que no necesitan un medio material para propagarse, se propagan mediante una oscilación de campos eléctricos o magnéticos que son soportes de las telecomunicaciones) ${ }^{12}$.

- Transmitir: conducir o ser el medio a través del cual se difunde el contenido de emisiones de radio y televisión. 
- Difundir: propagar o divulgar conocimientos, noticias, actitudes, costumbres, etc.

- Distribuir: dar a algo su oportuna colocación o el destino conveniente.

- Recepcionar: recibir las ondas de trasmisión.

A partir de esto se pueden advertir las siguientes diferencias significativas entre el servicio de televisión y el acceso a contenidos multimedia de video a través de la tecnología de streaming:

\begin{tabular}{|l|l|}
\hline \multicolumn{1}{|c|}{ Streaming } & \multicolumn{1}{|c|}{ Televisión } \\
\hline $\begin{array}{l}\text { Es una tecnología que } \\
\text { permite acceder a con- } \\
\text { tenidos multimedia de } \\
\text { audio y video. }\end{array}$ & $\begin{array}{l}\text { Es un servicio que emite y } \\
\text { transmite contenidos de au- } \\
\text { dio y video a través de una } \\
\text { programación fijada por los } \\
\text { canales que la componen. }\end{array}$ \\
\hline $\begin{array}{l}\text { Permite visualizar a los } \\
\text { suscriptores los conte- } \\
\text { nidos que solicita y le } \\
\text { permite controlar su re- } \\
\text { producción. }\end{array}$ & $\begin{array}{l}\text { Transmite contenidos y el } \\
\text { espectador se conecta para }\end{array}$ \\
\hline $\begin{array}{l}\text { Aloja sus contenidos } \\
\text { propios o adquiridos } \\
\text { en servidores web a los } \\
\text { cuales el suscriptor se } \\
\text { conecta para acceder a } \\
\text { los mismos. }\end{array}$ & $\begin{array}{l}\text { Transmite a través de ondas } \\
\text { electromagnéticas los conte- } \\
\text { nidos desde las productoras } \\
\text { a las antenas de los opera- } \\
\text { dores, quienes la recepcio- } \\
\text { nan y, en algunos casos, la } \\
\text { codifican para entregarla a } \\
\text { los suscriptores del servicio, }\end{array}$ \\
\hline
\end{tabular}

Fuente: Elaboración propia.

\section{Diferencias entre streaming y televisión}

Igualmente, al analizar las formas contractuales de suscripción de cada uno de los medios citados para acceder a contenido de video, tomando como ejemplo los previstos por Netflix ${ }^{13}$ y Colombia Telecomunicaciones S.A. E.S.P ${ }^{14}$, se halla:

\section{Diferencias en los contratos suscritos en streaming y servicio de televisión}

\begin{tabular}{|c|c|}
\hline Netflix & $\begin{array}{l}\text { Colombia Telecomu- } \\
\text { nicaciones S.A. E.S.P }\end{array}$ \\
\hline $\begin{array}{l}\text { Brinda una suscripción que } \\
\text { permite a sus miembros ac- } \\
\text { ceder a películas y progra- } \\
\text { mas de televisión (contenido } \\
\text { Netflix) trasmitidos a través } \\
\text { de internet a ciertos televi- } \\
\text { sores y otros dispositivos co- } \\
\text { nectados a internet. Durante } \\
\text { la membresía de Netflix se } \\
\text { otorga una licencia limitada, } \\
\text { no exclusiva e intransferible } \\
\text { para acceder a los contenidos } \\
\text { de Netflix con el propósito } \\
\text { de ver contenido de Netflix } \\
\text { a través del servicio de strea- } \\
\text { ming, y dicha licencia no le } \\
\text { transfiere ningún derecho o tí- } \\
\text { tulo al suscriptor. El software } \\
\text { de Netflix es desarrollado por } \\
\text { Netflix o a pedido de Netflix y } \\
\text { fue diseñado para permitir ver } \\
\text { contenido a través de disposi- } \\
\text { tivos listos para Netflix. }\end{array}$ & $\begin{array}{l}\text { Presta al suscriptor el } \\
\text { servicio de televisión } \\
\text { por suscripción, me- } \\
\text { diante el cual puede ac- } \\
\text { ceder a ciertos canales } \\
\text { de televisión que com- } \\
\text { ponen la programación } \\
\text { de servicios que recibe. } \\
\text { Este servicio se reci- } \\
\text { be a través de equipos } \\
\text { constitutivos de antena, } \\
\text { smartcards, decodifica- } \\
\text { dor y cableado, los cua- } \\
\text { les son de propiedad de } \\
\text { Colombia Telecomu- } \\
\text { nicaciones S.A. E.S.P, } \\
\text { entregados a título de } \\
\text { comodato. }\end{array}$ \\
\hline
\end{tabular}

Fuente: Elaboración propia a partir de la información prevista en los términos de uso fijados por Netflix a sus suscriptores y en el contrato de servicio de televisión firmado por Colombia Telecomunicaciones S.A. E.S.P.

Se evidencia claramente que las características de cada medio para acceder a contenidos de video son muy diferentes $y$, por tanto, no se pueden clasificar de forma igual, pues es

\footnotetext{
${ }^{13}$ Términos de uso suscritos por Netflix, recuperado de: https://help.netflix.com/legal/termsofuse ${ }^{14}$ Contrato de presentación del servicio de televisión suscrito por Colombia de Telecomunicaciones S.A.ESP, recuperado de: https://www.movistar.co/documents/10184/561805/Contrato+de+Servi cios+de+Televisi\%C3\%B3n.pdf/42780e4d-237b-4fea-a70e-6d351048a15e
} 
bastante claro que el servicio de televisión posee unas características propias que no se ajustan a las características del streaming, que más que un servicio es una tecnología que permite el acceso a contenidos de video.

\section{C.Tarifa}

En Colombia, la tarifa del impuesto sobre la renta es general para todas las personas jurídicas que perciben ingresos gravados con dicho impuesto. La misma es fijada en el Artículo 240 del Estatuto Tributario, que al tenor indica:

Art. 240. Tarifa general para personas jurídicas. * -Modificado por la Ley 1819 de 2016 Art. 100.-

La tarifa general del impuesto sobre la renta aplicable a las sociedades nacionales y sus asimiladas, los establecimientos permanentes de entidades del exterior y las personas jurídicas extranjeras o sin residencia obligadas a presentar la declaración anual del impuesto sobre la renta y complementarios, será del $33 \%$.
Por tanto, se puede advertir que el impuesto sobre la renta que deberán reconocer, declarar y pagar las sociedades extranjeras no residentes en Colombia que proveen streaming en el territorio nacional será del $33 \%$ de los ingresos que sean susceptibles de incrementar su patrimonio, al estar clasificados los mismos como ingresos de fuente nacional. Por ello y teniendo en cuenta que dichas sociedades no se han dado de alta en el territorio nacional como contribuyentes de dicho impuesto y no se encuentran inscritas como responsables de este tributo ante la Administración Tributaria, el gobierno nacional ha implementado algunos mecanismos de recaudo como los que se detallan a continuación.

\section{Mecanismos de recaudo}

En virtud de que las sociedades extranjeras sin sucursal o establecimiento permanente son contribuyentes del impuesto de renta por los ingresos de fuente nacional, el Estado colombiano, en ejercicio de la facultad consagrada en los Artículos 365, 366 y 3661 del Estatuto Tributario ${ }^{15}$, ha establecido 
en su legislación doméstica un mecanismo anticipado de recaudo de dicho tributo, denominado retención en la fuente sobre pagos al exterior, el cual se encuentra reglado en el Artículo 406 del Estatuto Tributario, que establece:

Artículo 406. [Creado por los Núm. 1, 2 y 3 del Inc. 1 del Art. 47 de la L. 9 de 1983] Casos en que debe efectuarse la retención. Deberán retener a título de impuesto sobre la renta, quienes hagan pagos o abonos en cuenta por concepto de rentas sujetas a impuesto en Colombia, a favor de:

1. Sociedades u otras entidades extranjeras sin domicilio en el país.

2. Personas naturales extranjeras (1) sin residencia en Colombia.

3. Sucesiones ilíquidas de extranjeros (1) que no eran residentes en Colombia.

Las retenciones previstas en el artículo mentado se deben practicar por los conceptos y tarifas previstas en los Artículos 407 al 415 del estatuto tributario así:

Conceptos y tarifas de retención en la fuente sobre pagos al exterior

\begin{tabular}{|c|l|c|c|}
\hline Artículo & \multicolumn{1}{|c|}{ Concepto } & Tarifa & \multicolumn{1}{|c|}{ Observaciones } \\
\hline 407 & Dividendos o participaciones & $5 \%$ & $\begin{array}{l}\text { Remite a Artículos } 391 \text { y } 245 \text { del } \\
\text { Estatuto Tributario. }\end{array}$ \\
\hline 408 & Rentas de capital y trabajo & $15 \%$ & \\
\hline & $\begin{array}{l}\text { - Intereses } \\
\text { - Comisiones } \\
\text { - Regonorarios } \\
- \text { Arrendamientos } \\
- \text { Compensaciones por servicios personales. Explotación } \\
\text { de toda especie de propiedad industrial o del know-how } \\
- \text { Prestación de servicios técnicos o de asistencia técnica } \\
\text { prestados por personas no residentes no domiciliadas en } \\
\text { Colombia que se presten en el país o desde el exterior } \\
- \text { Beneficios o regalías provenientes de la propiedad lite- } \\
\text { raria, artística y científica }\end{array}$ & \\
\hline
\end{tabular}

(Continúa)

Art. 366. Facultad para establecer nuevas retenciones.

Sin perjuicio de las retenciones contempladas en las disposiciones vigentes el 27 de diciembre de 1984, el Gobierno podrá establecer retenciones en la fuente sobre los pagos o abonos en cuenta susceptibles de constituir ingreso tributario para el contribuyente del impuesto sobre la renta, que hagan las personas jurídicas y las sociedades de hecho.

Los porcentajes de retención no podrán exceder del tres por ciento $(3 \%)$ del respectivo pago o abono en cuenta. (Hoy la retención por otros ingresos tributarios se fijó en el 3,5\%). En todo lo demás, se aplicarán las disposiciones vigentes sobre la materia.

Art. 366-1. Facultad para establecer retención en la fuente por ingresos del exterior.

Sin perjuicio de las retenciones en la fuente consagradas en las disposiciones vigentes, el Gobierno Nacional podrá señalar porcentajes de retención en la fuente no superiores al treinta por ciento (30\%) del respectivo pago o abono en cuenta, cuando se trate de ingresos constitutivos de renta o ganancia ocasional, provenientes del exterior en moneda extranjera, independientemente de la clase de beneficiario de los mismos... 


\section{Conceptos y tarifas de retención en la fuente sobre pagos al exterior (continuación)}

\begin{tabular}{|c|c|c|c|}
\hline Artículo & Concepto & Tarifa & Observaciones \\
\hline & $\begin{array}{l}\text { - Rendimientos financieros, realizados a personas no resi- } \\
\text { dentes o no domiciliadas en el país, originados en créditos } \\
\text { obtenidos en el exterior por término igual o superior a } \\
\text { un (1) año } \\
\text { - Intereses o costos financieros del canon de arrendamiento } \\
\text { originados en contratos de leasing que se celebren direc- } \\
\text { tamente o a través de compañías de leasing con empresas } \\
\text { extranjeras sin domicilio en Colombia }\end{array}$ & $15 \%$ & \\
\hline \multirow[t]{4}{*}{408} & $\begin{array}{l}\text { - Contratos de leasing sobre naves, helicópteros y/o aero- } \\
\text { dinos, así como sus partes, que se celebren directamente o } \\
\text { a través de compañías de leasing, con empresas extranjeras } \\
\text { sin domicilio en Colombia }\end{array}$ & $1 \%$ & \\
\hline & $\begin{array}{l}\text { - Rendimientos financieros o intereses, realizados a perso- } \\
\text { nas no residentes o no domiciliadas en el país, originados } \\
\text { en créditos o valores de contenido crediticio, por término } \\
\text { igual o superior a ocho ( } 8 \text { ) años, destinados a la finan- } \\
\text { ciación de proyectos de infraestructura bajo el esquema } \\
\text { de Asociaciones Público-Privadas en el marco de la Ley } \\
1508 \text { de } 2012\end{array}$ & $5 \%$ & \\
\hline & $\begin{array}{l}\text { - Prima cedida por reaseguros realizados a personas no } \\
\text { residentes o no domiciliadas en el país }\end{array}$ & $1 \%$ & \\
\hline & $\begin{array}{l}\text { - Pagos o abono en cuenta por concepto de administración } \\
\text { o dirección de que trata el Artículo } 124 \text { del estatuto tribu- } \\
\text { tario, realizado a personas no residentes o no domiciliadas } \\
\text { en el país }\end{array}$ & $15 \%$ & $\begin{array}{l}\text { Art. } 124 \text { E.T. Gastos de admi- } \\
\text { nistración o dirección y por con- } \\
\text { cepto de regalías y explotación o } \\
\text { adquisición de intangibles reali- } \\
\text { zado por las subsidiarias de las } \\
\text { casas matriz }\end{array}$ \\
\hline 409 & $\begin{array}{l}\text { Rentas de profesores extranjeros sin residencia en el país } \\
\text { contratados por periodos superiores a } 4 \text { meses en Insti- } \\
\text { tuciones de Educación Superior aprobadas por el ICFES }\end{array}$ & $7 \%$ & \\
\hline 410 & Explotación de películas cinematográficas & $15 \%$ & \\
\hline 411 & Explotación programas de computador a cualquier título & $33 \%$ & $\begin{array}{l}\text { La tarifa se aplica sobre el } 80 \% \\
\text { del valor del pago o abono en } \\
\text { cuenta }\end{array}$ \\
\hline 412 & Contrato "llave de mano" de más contratos de obra material & $1 \%$ & $\begin{array}{l}\text { Aplica para nuevos contratos, o } \\
\text { modificación o prórrogas de los } \\
\text { ya existentes, a partir del 24-12- } \\
1986 \text { (Art. 123 ET) }\end{array}$ \\
\hline 414 & $\begin{array}{l}\text { Arrendamiento de maquinaria para construcción, mante- } \\
\text { nimiento o reparación de obras civiles }\end{array}$ & $2 \%$ & \\
\hline $414-1$ & Transporte internacional & $5 \%$ & \\
\hline \multirow[t]{2}{*}{415} & $\begin{array}{l}\text { - Demás conceptos no contemplados en los artículos ante- } \\
\text { riores diferentes a ganancias ocasionales }\end{array}$ & $15 \%$ & \\
\hline & - Ganancias ocasionales & $10 \%$ & \\
\hline
\end{tabular}

Fuente: Creación propia a partir del contenido de los Artículos 408 al 415 del Estatuto Tributario. 
En virtud de este mecanismo implementado en la legislación tributaria colombiana, para recaudar anticipadamente el impuesto de renta generado por los ingresos de fuente nacional percibidos por las sociedades extranjeras sin sucursal o establecimiento permanente en el país, se advierte en el Artículo 592 del Estatuto Tributario que se exonera del deber de presentar la declaración de renta anual fijada en el Artículo 591 del Estatuto Tributario, a las sociedades extranjeras sin domicilio en el país, cuando la totalidad de sus ingresos hubieran estado sometidos a retención en la fuente de que tratan los Artículos 407 al 415 del Estatuto Tributario, lo cual ha sido corroborado en diferentes conceptos expedidos por la Administración Tributaria ${ }^{16}$.

Igualmente, revisada la legislación tributaria colombiana, se evidencia que existe una retención en la fuente específica para cuando se realizan los pagos a través de tarjetas de crédito o tarjetas débito, la cual está contemplada en los Decretos 406 y 556 de 2001, compilados en los Artículos 1.3.2.1.2 y 1.3.2.1.8 del Decreto Único Reglamentario 1625 de 2016, que indican:

Artículo 1.3.2.1.8 Decreto 1625 de 2016. (Decreto 406 de 2001. Artículo 17). Retención en la fuente sobre ingresos de tarjetas de crédito y/o débito. Los pagos o abonos en cuenta susceptibles de constituir ingreso tributario para los contribuyentes del impuesto sobre la renta, por concepto de ventas de bienes o servicios realizadas a través de los sistemas de tarjetas de crédito y/o débito, están sometidos a retención en la fuente a la tarifa del uno punto cinco por ciento (1.5\%).

La retención deberá ser practicada por las respectivas entidades emisoras de las tarjetas de crédito y/o débito, en el momento del correspondiente pago o abono en cuenta a las personas o establecimientos afiliados, sobre el valor total de los pagos o abonos efectuados, antes de descontar la comisión que corresponde a la emisora de la tarjeta y descontado el impuesto sobre las ventas generado por la operación gravada.

Las declaraciones y pagos de los valores retenidos de acuerdo con este artículo deberán efectuarse en las condiciones y términos previstos en las disposiciones vigentes.

Parágrafo $1^{\circ}$. Cuando los pagos o abonos en cuenta a que se refiere este artículo correspondan a compras de bienes o servicios para los cuales disposiciones especiales establezcan tarifas de retención en la fuente inferiores al uno punto cinco por ciento (1.5 $\%)$, se aplicarán las tarifas previstas en cada caso por tales disposiciones.

Parágrafo $2^{\circ}$. Cuando los pagos o abonos en cuenta incorporen el valor de otros impuestos, tasas y contribuciones, diferentes del impuesto sobre las ventas, para calcular la base de retención se descontará el valor de los impuestos, tasas y contribuciones incorporados, siempre que los beneficiarios de dichos pagos o abonos tengan la calidad de responsables o recaudadores de los mismos.

${ }^{16}$ Conceptos DIAN 33112 de 2015 y 16385 de 2015. 
También se descontará de la base el valor de las propinas incluidas en las, sumas a pagar.

Las declaraciones y pagos de los valores retenidos de acuerdo con este artículo deberán efectuarse en las condiciones y términos previstos en las disposiciones vigentes.

Artículo 1.3.2.1.2 Decreto 1625 de 2016. (Decreto 556 de 2001. Artículo $1^{\circ}$ ). Otros agentes de retención en la fuente sobre ingresos de tarjetas de crédito y/o débito. Cuando los pagos o abonos en cuenta susceptibles de constituir ingreso tributario a favor de las personas o establecimientos afiliados a los sistemas de tarjetas de crédito o débito se realicen por intermedio de las entidades adquirentes o pagadoras, la retención en la fuente deberá ser practicada por dichas entidades conforme a la tarifa, base y, demás condiciones previstas por el artículo 1.3.2.1.8 del presente decreto.

Al respecto, la doctrina de la $\operatorname{DIAN}^{17}$ ha fijado que el agente retenedor que debe practicar este tipo de retención son las entidades emisoras de las tarjetas, en el momento del correspondiente pago o abono en cuenta a las personas y establecimientos afiliados, por tanto, el tarjetahabiente que posee la calificación de agente de retención que utiliza la tarjeta de crédito o débito como medio de pago no debe practicar la retención en razón a que no está facultado para ello, y al practicarla este último estaría en presencia de una doble retención, la cual resulta improcedente. Así mismo, la doctrina ${ }^{18}$ ha aclarado que cuando el medio de pago es a través de tarjetas de crédito o débito, la tarifa de retención en la fuente es del 1,5\%, independientemente de la tarifa fijada para cada concepto en la normatividad pertinente.

De acuerdo con la legislación mentada, Colombia ha implementado como mecanismo de recaudo anticipado del impuesto de renta la retención en la fuente, dentro del cual se contemplan los conceptos de pagos al exterior como mecanismo de recaudo del impuesto de renta sobre ingresos de fuente nacional percibidos por las sociedades extranjeras no residentes que perciben rentas en el país, los cuales están sujetos a retención en la fuente en las tarifas previstas en los Artículos 407 al 418 del Estatuto Tributario ${ }^{19}$.

Teniendo en cuenta la calificación de las rentas percibidas por las sociedades extranjeras no residentes que proveen streaming en el país, se identifica que la retención en la fuente aplicable a las mismas es la prevista en el Artículo 408 del Estatuto Tributario, la cual fija una tarifa de retención del $15 \%$ del valor nominal del pago o abono en cuenta de regalías por la explotación de toda especie de propiedad industrial.

Así mismo, al respecto, la doctrina ha citado, en el Oficio 060826 del 20 de junio de 2008 , emitido por la Administración Tributaria:

\footnotetext{
${ }^{17}$ Concepto DIAN 68810 de 2001.

${ }^{18}$ Concepto DIAN 69307 de 2010.

${ }^{19}$ Decreto 624 de 1989.
} 
...Ahora bien, en cuanto a la tarifa de retención en la fuente por explotación de propiedad intelectual por extranjeros sin residencia o domicilio en el país, el concepto 037529 de 2002, señaló en algunos de sus apartes: Conforme con lo expuesto en los artículos 12 y 20 del Estatuto Tributario las sociedades y entidades extranjeras de cualquier naturaleza, son contribuyentes del impuesto sobre la renta y complementarios únicamente sobre sus rentas y ganancias ocasionales de fuente nacional, salvo las excepciones especificadas en los pactos internacionales y en el Derecho interno.

\section{El Artículo 24 del Estatuto Tributario es-} tablece:

Ingresos de fuente nacional. Se consideran ingreso de fuente nacional los provenientes de la explotación de bienes materiales e inmateriales dentro del país y la prestación de servicios dentro de su territorio de manera permanente o transitoria, con o sin establecimiento propio; así como el obtenido en la enajenación de bienes materiales e inmateriales, a cualquier título, que se encuentren dentro del país al momento de su enajenación. Los ingresos de fuente nacional incluyen, entre otros, los siguientes:

/.../

7. Los beneficios o regalías de cualquier naturaleza provenientes de la explotación de toda especie de propiedad industrial, o del "Know how" o de la prestación de servicios de asistencia técnica, sea que éstos se suministren desde el exterior o en el país.
Igualmente, los beneficios o regalías provenientes de la propiedad literaria, artística y científica explotada en el país.

A su vez, el Artículo 408 ibídem establece la tarifa para rentas de capital y de trabajo, así:

Tarifas para rentas de capital y de trabajo. En los casos de pagos o abonos en cuenta por concepto de intereses, comisiones, honorarios, regalías, arrendamientos, compensaciones por servicios personales, o explotación de toda especie de propiedad industrial o del "know-how", prestación de servicios técnicos o de asistencia técnica, beneficios o regalías provenientes de la propiedad literaria. artística y científica, la tarifa de retención será del treinta y cinco por ciento $(35 \%)$ del valor nominal del pago o abono...

Esta retención sería aplicable en el evento de las transacciones realizadas bajo la modalidad de comercio electrónico B2B (businessto-business), es decir, cuando la suscripción de streaming se transa con una persona jurídica en Colombia, a quien le reviste la responsabilidad de agente de retención o de autorretenedor de que tratan los Artículos 368 y 368-2 del Estatuto Tributario ${ }^{20}$, que le obligan a practicar retenciones en la fuente en los pagos o abonos en cuenta que realice; en lo que respecta a las transacciones bajo la modalidad de comercio electrónico B2C (business-to-consumer), es decir, cuando la suscripción de streaming se realice por una persona física, se podrá practicar retención en la fuente solo en los eventos en que dichas

${ }^{20}$ Decreto 624 de 1989. 
personas posean la responsabilidad tributaria de agente de retención o de autorretenedor, que para el caso colombiano solo una pequeña proporción, que representa menos del $15 \%$ de los contribuyentes personas naturales, la posee.

Igualmente, vale la pena acotar que esta retención solo sería aplicable en el caso en que los pagos se realizaran en efectivo, transferencia bancaria o giro directo, pues la normatividad tributaria colombiana contempla una retención específica para cuando los pagos se realizan con sistema de pago de tarjeta crédito o tarjeta débito, la cual está compilada en el Artículo 1.3.2.1.8 (Artículo 17 del Decreto 406 de 2001) y 1.3.2.1.2 (Artículo 1 del Decreto 556 de 2001) del Decreto 1625 de 2016, que fija una tarifa de retención en la fuente del 1,5\% sobre las ventas de bienes o servicios realizadas a través de los sistemas de tarjetas de crédito y/o débito, la cual deberá ser practicada por las respectivas entidades emisoras de las tarjetas de crédito y/o débito, en el momento del correspondiente pago o abono en cuenta a las personas o establecimientos afiliados, sobre el valor total de los pagos o abonos efectuados, antes de descontar la comisión que corresponde a la emisora de la tarjeta y descontado el impuesto sobre las ventas generado por la operación gravada.

Al respecto, la doctrina ${ }^{21}$ se ha pronunciado en diversas ocasiones, indicando el momento en que se debe practicar la retención en la fuente, el agente retenedor que está obligado a practicarla y la tarifa que se le debe aplicar, determinando que la misma se practica en el momento del pago del operador de tarjeta de crédito o tarjeta débito al establecimiento afiliado, el agente retenedor es la entidad financiera operadora de la tarjeta de crédito y la tarifa máxima es de 1,5\%, independientemente de que las tarifas previstas en los Artículos 407 al 415 del Estatuto Tributario contemplen tarifas superiores, como es el caso de análisis que estaría sujeto a una retención del $15 \%$ del valor del pago o abono en cuenta según lo contemplado en el párrafo 1 del Artículo 408 del Estatuto Tributario. Para el caso de los pagos realizados con tarjetas crédito y tarjetas débito internacionales, emitidas por entidades no residentes en el país, es claro que la retención en la fuente citada no sería procedente aplicarla por la entidad emisora, pues la responsabilidad tributaria de ser agente de retención cobija a los contribuyentes con domicilio fiscal en el territorio nacional, y la misma les obliga a practicar las retenciones en la fuente respectivas sobre todos y cada uno de los pagos o abonos en cuenta que estén sujetos a estas.

Así mismo, es viable contemplar qué retención aplicaría en el caso de que el medio de pago se constituyera a través de pasarelas o servicios de pago y/o criptomonedas, toda vez que las transacciones de suscripción de streaming al realizarse de forma virtual son susceptibles de usar estos medios de pago.

Por tanto, al analizar la operación de los servicios o pasarelas de pago, se evidencia

${ }^{21}$ Concepto 68810 de 2001, 69307 de 2010 y 34880 de 2016. 
que estas actúan dentro del comercio electrónico bajo la figura de contrato de mandato de gestión de pagos, el cual trasladará las retenciones en la fuente practicadas por las entidades emisoras de tarjeta de crédito y tarjeta débito a la sociedad extranjera no residente que utilice sus servicios, que en últimas resulta ser el beneficiario del pago. Igualmente, trasladará las retenciones en la fuente que se le practiquen cuando los pagos recibidos se realicen en efectivo, giro directo o transferencia bancaria.

Respecto a las criptomonedas, las mismas se transan a través de casas de cambio, mediante las cuales se suscriben las billeteras virtuales. En Colombia, se cuenta con una casa de cambio de este tipo de pago operada por la sociedad SurBTC S.A.S., que opera a través del sitio web www.buda.com y en el cual se constituyen las billeteras virtuales. Este tipo de medio de pago en la actualidad no está sujeto a retención en la fuente de forma directa, solo le son aplicables las retenciones generales previstas en el ordenamiento tributario colombiano que deben ser practicadas por los agentes de retención. Por tanto, en el caso en que la suscripción de streaming se pueda cancelar por este medio de pago, las personas que no poseen la responsabilidad de agentes de retención no practicarían retención alguna y el Estado colombiano no podría recaudar el impuesto de renta que genera dichas transacciones, razón por la cual se estima que sería viable extender lo normado para las entidades emisoras de tarjetas de crédito y tarjeta debito en lo que respecta a practicar retención en la fuente sobre los pagos o abonos en cuenta realizados con estos medios de pago a las casas de cambio de criptomonedas que emiten billeteras virtuales, pues se puede advertir que su operatividad es similar, ya que estas permiten adquirir las criptomonedas, venderlas y, cuando se realizan transacciones, transferir el recurso al establecimiento comercial que las recibe en contraprestación de la venta o prestación de servicio.

En virtud de lo esbozado anteriormente y teniendo en cuenta el valor de los ingresos percibidos por las sociedades extranjeras no residentes en Colombia por suscripciones de streaming de usuarios residentes y/o domiciliados en el país para el año 2015, que fueron presentados por el Departamento Nacional de Planeación - DNP en el foro "El futuro del sector audiovisual en el mercado de la convergencia tecnológica en Colombia"22, es necesario que Colombia, a través de la Dirección de Impuestos y Aduanas Nacionales - DIAN, imparta una directiva a las entidades emisoras de las tarjetas crédito y tarjetas débito en Colombia y a las entidades distribuidoras de streaming para que practiquen las retenciones mentadas, pues con ello el Estado percibiría más de \$194.021 millones de pesos de impuesto de renta que hoy por hoy las sociedades extranjeras no residentes en Colombia proveedoras de streaming no tributan en el país.

\footnotetext{
${ }^{22}$ Recuperado de: https://www.dnp.gov.co/Paginas/DNP-propone-revolc\%C3\%B3n-enregulaci\%C3\%B3n-TIC-y-audiovisual-en-Colombia.aspx.
} 
Dicha cifra se estima a partir de los datos detallados a continuación, extraídos del informe presentado por el DNP en el foro referenciado, sin tener en cuenta las suscripciones de otros proveedores de streaming representativos como Spotify y Hulu, entre otros.

\section{Ingresos de iTunes en Colombia}

Tabla 5.

Cálculo de impuesto de renta retenido estimado sobre valor total de suscripciones de streaming colocadas por Netflix e ITunes

\begin{tabular}{|l|c|c|}
\hline $\begin{array}{c}\text { Proveedor } \\
\text { de } \\
\text { streaming }\end{array}$ & $\begin{array}{c}\text { Valor } \\
\text { suscripciones } \\
\text { aproximado } \\
2015 \text { (valores } \\
\text { en millones de } \\
\text { pesos) }\end{array}$ & $\begin{array}{c}\text { Valor impuesto sobre } \\
\text { la renta retenido } \\
\text { bajo la concepción de } \\
\text { pagos con tarjeta de } \\
\text { crédito y tarjeta debito } \\
\text { (tarifa del 1,5\%) }\end{array}$ \\
\hline Netflix & $145.726 *$ & 2.186 \\
\hline iTunes & $12.788 .992 * *$ & 191.835 \\
\hline
\end{tabular}

* $66.1 \%$ de 70 millones de dólares, calculados a partir del TRM a 31-12-2015 \$3.149,47

** $1.6 \%$ del PIB de 2015

Fuente: Elaboración propia a partir de los datos presentados por DNP en el foro "El futuro del sector audiovisual en el marco de la convergencia tecnológica en Colombia

\section{E. Convenios para evitar la doble imposición}

En los apartes anteriores, se bosqueja todo lo concerniente al impuesto de renta en la legislación doméstica colombiana desde la perspectiva del Estado fuente de los ingresos percibidos por las sociedades extranjeras no residentes en el país que proveen streaming en el territorio nacional, a fin de evaluar la tributación internacional, y si en esta se da el fenómeno de doble imposición, se hace necesario analizar algunas generalidades sobre la normatividad tributaria internacional prevista en los convenios para evitar la doble imposición (en adelante CDI).

Partiendo de la definición de CDI como un acuerdo de voluntades entre dos Estados a fin de distribuir la potestad tributaria para gravar las rentas obtenidas por sus residentes fiscales en el otro Estado y así evitar que sus residentes estén sometidos a doble imposición y teniendo en cuenta las siguientes reglas de atribución de la potestad tributaria que se pactan en estos acuerdos según el tipo de renta.

- Rentas gravadas exclusivamente en el país de residencia del beneficiario, cediendo su potestad tributaria de gravarlas el Estado fuente,

- Rentas gravadas en el Estado de residencia del beneficiario y en el Estado fuente, con limitaciones para ser gravadas por el Estado fuente.

- Rentas gravadas sin ningún límite en el Estado de residencia y en el Estado fuente.

Se puede determinar que si los ingresos percibidos por las sociedades extranjeras no residentes en Colombia por proveer streaming en el territorio nacional son consideradas en la legislación doméstica como regalías por la explotación de propiedad industrial constituida en la tecnología de streaming, lo que resulta concordante con la definición dada en el Artículo 12 del modelo de convenio para evitar la doble imposición de la OCDE, el cual, en el párrafo 2, cita: "El término "regalías" en el sentido de este articulo significa las cantidades de cualquier clase pagadas por el uso o la concesión de uso de derechos de autor sobre obras literarias, artísticas o científicas, incluidas las películas cinematográficas, 
de patentes, marcas, diseños o modelos, planos, formulas o procedimientos secretos o por informaciones relativas a experiencias industriales, comerciales o científicas". Por tanto, las rentas percibidas por las sociedades extranjeras sin domicilio en el país que proveen streaming en el territorio nacional, bajo la óptica de los convenios para evitar la doble imposición, se califican como regalías, pues es claro en el análisis realizado a los términos de uso suscritos en las membresías de streaming que la licencia otorgada al usuario que suscribe la membresía es para el uso limitado de la tecnología y que con la misma no se transfiere ningún derecho a título. Por tanto, el pago realizado mensualmente en virtud del acuerdo de licencia suscrito constituye una regalía conforme lo previsto en el Artículo 12 del modelo de convenio para evitar la doble imposición de la OCDE esbozado anteriormente, lo cual a su vez ha sido previsto en la doctrina emitida por la Administración tributaria colombiana, que ha fijado en diferentes conceptos como línea doctrinal:

Tratándose de intangibles independientemente de su denominación si lo que subyace una operación es la autorización para uso de un software sin que el titular se desprenda de un derecho de propiedad, el pago por dicho concepto corresponde a un canon o regalía, por el contrario, si hay transferencia de la titularidad del derecho patrimonial de propiedad en todos sus elementos, esta retribución no puede constituir una regalía y tales pagos pueden constituir rentas de actividades empresariales $^{23}$.

Ahora bien, partiendo de la calificación dada como regalía a los ingresos percibidos por las sociedades extranjeras sin domicilio en el país que proveen streaming en el territorio nacional, se puede determinar el tratamiento dado a las mismas en lo que respecta a la distribución de la potestad tributaria adoptada por el modelo de convenio para evitar la doble imposición de la OCDE, el cual es plasmado en el párrafo 1 del Artículo 12, que cita: "Las regalías procedentes de un estado contratante y cuyo beneficiario efectivo es un residente del otro estado contratante solo puede someterse a imposición en ese otro estado".

De lo anterior se puede advertir que el Estado fuente transfiere la potestad tributaria de gravar las rentas por regalías exclusivamente al Estado de residencia, lo cual, en palabras de Catalina Hoyos, "obedece a que el país de residencia es el que se ve afectado por los costos que implican el desarrollo de la propiedad intelectual de cuya explotación proviene las regalías".

Por esta razón, vale la pena resaltar lo citado por Zulay Arévalo24: "el Artículo 12 del modelo de convenio para evitar la doble imposición de la OCDE, no precisa si la exención en el estado de la fuente de la regalía se

\footnotetext{
${ }^{23}$ Conceptos DIAN 54648 de 2007, 95029 de 2009, 81572 de 2011, 125326 de 2000, 60826 de 2008 y 110964 de 2001.

${ }^{24}$ Ponencia “Tributación de intangibles en Colombia”, en XXIX Jornada Colombianas de Derecho Tributario, Cartagena de Indias, Instituto Colombiano de Derecho Tributario, 2005.
} 
encuentra subordinada a que estén gravadas en el estado de la residencia según los comentario de la OCDE esto debe ser definido por los estados contratantes"; que en concordancia con el párrafo 4 de los comentario del Artículo 12 del modelo de convenio para evitar la doble imposición de la OCDE permitirá indicar que esta desgravación en el Estado fuente, es decir, en Colombia, se puede condicionar o eximir si se determina que el beneficiario efectivo de la renta percibida se encuentra en otro Estado y que, por tanto, dicha renta no será gravada en el Estado de residencia del receptor del pago, ya que no se tendría una doble imposición y su desgravación resultaría contradictoria a los objetivos del convenio.

Al respecto, se debe aclarar que Colombia en los CDI suscritos ha incluido unas variaciones al modelo OCDE que atienden a las circunstancias de la legislación interna. Entre estas se halla el tratamiento dado a las rentas por cánones o regalías, en cuanto a las cuales ha introducido la potestad tributaria del Estado fuente para gravarlas con un impuesto máximo del $10 \%$ sobre el importe bruto del canon o regalía, cuando el beneficiario efectivo sea un residente del otro Estado contratante.

Lo anterior se describe teniendo en cuenta que la mayoría de los Estados adoptan el modelo OCDE en los CDI suscritos, igualmente, por tanto, se hace necesario listar los países con los cuales los Estados analizados en la presente investigación (Colombia, Países Bajos y Estados Unidos de América) han suscrito convenios bajo este modelo.

En la actualidad, Colombia ha suscrito convenios para evitar la doble imposición con los siguientes Estados:
- España

- Chile

- Suiza

- Canadá

- México

- Corea

- India

- República Checa

- Portugal (Dian, 2017)

- Japón (Ministerio de Hacienda, 2017)

- Emiratos Árabes Unidos

- Reino Unido de Gran Bretaña e Irlanda

- Francia (Cancillería, 2017).

De lo descrito, se advierte que Colombia no posee CDI suscrito con los Países Bajos ni con los Estados Unidos de América, principales Estados de residencia de las sociedades extranjeras no residentes en Colombia que proveen streaming en el territorio nacional; así mismo, se puede indicar que en el evento en que el Estado de residencia de alguna de las sociedades extranjeras no residentes en Colombia que proveen streaming en el territorio nacional posea CDI suscrito con el estado colombiano, las rentas percibidas por estas sociedades serán gravadas con el impuesto de renta en Colombia a una tarifa máxima del $10 \%$ según la variación introducida al Modelo OCDE en los CDI suscritos por Colombia.

\section{Impuesto al Valor Agregado - IVA en la Economía Digital para sociedades extranjeras no residentes que operan streaming en Colombia}

\section{A.Sujetos pasivos}

Se consideran responsables del Impuesto al Valor Agregado - IVA dentro del territorio nacional los enumerados en el Artículo 437 del Estatuto Tributario, el cual fija: 
Art. 437. Los comerciantes y quienes realicen actos similares a los de ellos y los importadores son sujetos pasivos.

Son responsables del impuesto:

a. En las ventas, los comerciantes, cualquiera que sea la fase de los ciclos de producción y distribución en la que actúen y quienes sin poseer tal carácter, ejecuten habitualmente actos similares a los de aquellos.

b. En las ventas de aerodinos, tanto los comerciantes como los vendedores ocasionales de éstos.

\section{c. Quienes presten servicios.}

d. Los importadores.

e. Los contribuyentes pertenecientes al régimen común del impuesto sobre las ventas, cuando realicen compras o adquieran servicios gravados con personas pertenecientes al régimen simplificado, por el valor del impuesto retenido, sobre dichas transacciones. f. **-Adicionado- Los contribuyentes pertenecientes al régimen común del Impuesto sobre las Ventas, por el impuesto causado en la compra o adquisición de los bienes y servicios gravados relacionados en el artículo 468-1, cuando estos sean enajenados o prestados por personas naturales no comerciantes que no se hayan inscrito en el régimen común del impuesto sobre las ventas. (Subrayado fuera del texto)

Respecto a los obligados fijados en el literal c) del Artículo 437 del Estatuto Tributario, se pueden advertir tres escenarios, a partir de la Ley 1819 de 2016, así:

Servicios prestados en Colombia por personas naturales o jurídicas residentes. En este, los responsables del IVA se encuentran en el territorio colombiano, y cobran, declaran y pagan el impuesto de forma ordinaria.
Servicios prestados desde Colombia al exterior. En este caso, se considera una exportación de servicios y, por tanto, están exentos conforme lo previsto en el Literal c) del Artículo 481 del Estatuto Tributario, siempre y cuando cumplan dichas condiciones; de lo contrario, se considerarán servicios prestados dentro del territorio nacional y se aplicará la tarifa general.

Servicio prestado desde el exterior para ser consumido o utilizado en Colombia. En este caso, se habla de una importación de servicios, respecto a lo cual el Artículo 178 de la Ley 1819 de 2016, introdujo el Parágrafo 2 al Artículo 437 del Estatuto Tributario, fijando:

PARÁGRAFO 2. La Dirección de Impuestos y Aduanas Nacionales establecerá mediante resolución el procedimiento mediante el cual los prestadores de servicios desde el exterior cumplirán con sus obligaciones, entre ellas la de declarar y pagar, en su calidad de responsables cuando los servicios prestados se encuentren gravados.

La Obligación aquí prevista solamente se hará exigible a partir del 1 de julio de 2018, salvo en aquellos casos previstos en el numeral 3 del artículo 437-2 de este Estatuto.

Por tanto, las sociedades extranjeras que proveen streaming en el territorio nacional, conforme lo previsto en el Parágrafo 2 del Artículo 420 del Estatuto Tributario, son catalogadas como prestadores de servicios en el país. Por tanto, al proveer streaming en el territorio nacional, realizan importación de servicios, razón por la cual estas sociedades deberán registrase ante la administración tributaria y cumplir su deber formal de cobrar, declarar y pagar el IVA, respecto a lo cual se 
fijará la reglamentación respectiva teniendo en cuenta lo previsto en la Sentencia C-009$03^{25}$ de la Corte Constitucional, en la cual se deja muy claro que los responsables del IVA régimen común son sujetos pasivos de la obligación tributaria, debiendo facturar el IVA causado y presentar oportunamente las declaraciones correspondientes con su respectivo pago.

\section{B. Hecho generador}

El hecho generador del Impuesto al Valor Agregado IVA se establece en el Artículo 420 del Estatuto Tributario, en el cual se fija:

Art. 420. Hechos sobre los que recae el impuesto.* -Modificado por la Ley 1819 de 2016 Art. 173.- El impuesto a las ventas se aplicará sobre:

a) La venta de bienes corporales muebles e inmuebles, con excepción de los expresamente excluidos.

b) La venta o cesiones de derechos sobre activos intangibles, únicamente asociados con la propiedad industrial.

c) La prestación de servicios en el territorio nacional, o desde el exterior, con excepción de los expresamente excluidos. d) La importación de bienes corporales que no hayan sido excluidos expresamente.

e) La circulación, venta u operación de juegos de suerte y azar, con excepción de las loterías y de los juegos de suerte y azar operados exclusivamente por internet (destacado fuera de texto).

Así, se configura como el elemento esencial para determinar la obligatoriedad del impuesto, conforme lo expresado por la Corte Constitucional en la Sentencia C-260 de 2015: "el hecho generador exige por parte del legislador la mayor claridad para poder determinar el alcance, de igual manera el legislador debe señalar sus elementos en forma clara e inequívoca, esto es, sujeto activo, sujeto pasivo, hecho generador, la base impositiva y la tarifa" (subrayado fuera de texto).

Como se observa dentro de los hechos sobre los cuales recae el IVA que se enumeran en el Artículo 420 del Estatuto Tributario, se halla descrita en el literal b) la venta o cesión de derechos sobre activos intangibles, asociados a la propiedad industrial. Al respecto, el mismo artículo, en el parágrafo 3 , aclara:

\footnotetext{
${ }^{25}$ Sentencia de la Corte Constitucional C-009-03: "De conformidad con los artículos 2 y 437 del Estatuto Tributario los responsables del impuesto sobre las ventas -régimen común- son sujetos pasivos de la obligación tributaria circunscritos a los deberes de hacer y no hacer, lo cual se traduce en una función intermediadora frente al IVA causado en cada transacción que realicen en su condición de vendedores de bienes o servicios. De suerte que en tales hipótesis los responsables deberán facturar el IVA causado legalmente en sus operaciones, así como presentar oportunamente la declaración bimestral aun cuando no hubiere ventas durante el respectivo bimestre, consignando al efecto el saldo a pagar por el respectivo período. Saldo que proviene de la depuración contable y fiscal que el responsable hace de sus operaciones bimestrales en torno a la causación del IVA, por donde, la naturaleza estatal de este recurso es consustancial a la condición de tributo que tiene el IVA; recurso estatal que temporalmente reposa en manos del responsable del impuesto sobre las ventas, es decir, dentro de los plazos previstos en las normas rectoras para declarar y consignar, sin que para nada importe el que el pago del bien o del servicio vendidos se verifiquen de contado o a crédito".
} 
Art. 420. Hechos sobre los que recae el impuesto.* -Modificado por la Ley 1819 de 2016 Art. 173

PARÁGRAFO 3. Para efectos del impuesto sobre las ventas, los servicios prestados y los intangibles adquiridos o licenciados desde el exterior se entenderán prestados, licenciados $o$ adquiridos en el territorio nacional y causarán el respectivo impuesto cuando el usuario directo o destinatario de los mismos tenga su residencia fiscal, domicilio, establecimiento permanente, o la sede de su actividad económica en el territorio nacional (destacado fuera del texto).

Respecto a esto, se puede advertir que el streaming provisto desde el exterior por las sociedades extranjeras que lo proveen en el territorio nacional cumple los preceptos del hecho generado previstos en el Artículo 420 del Estatuto Tributario, pues, como se expresó en el aparte II del Capítulo 2 del presente texto, las rentas percibidas por las sociedades proveedoras de streaming en el territorio nacional se categorizan como regalías por licenciamiento desde el exterior del streaming, como tecnología que permite acceder a contenidos multimedia visualizados en la página web del proveedor de streaming, tecnología esta que constituye propiedad industrial de las sociedades que la proveen en el territorio nacional. Por tanto, estas rentas estarían gravadas con el IVA, conforme lo previsto en el Parágrafo 3 del Artículo 420 del Estatuto Tributario, que incluye el licenciamiento de intangibles desde el exterior dentro de la venta o cesiones de derechos sobre activos intangibles previstos en el literal b) del mismo artículo.

Ahora bien, teniendo en cuenta que el presupuesto fáctico del hecho generador del im- puesto sobre las ventas se da en el momento en el que se cause dicho impuesto, es relevante citar, según la normatividad colombiana, en qué instante se da este presupuesto fáctico; al respecto, el Artículo 429 del Estatuto Tributario cita:

Art. 429. Momento de causación.

El impuesto se causa:

a. En las ventas, en la fecha de emisión de la factura o documento equivalente y a falta de éstos, en el momento de la entrega, aunque se haya pactado reserva de dominio, pacto de retroventa o condición resolutoria.

b. En los retiros a que se refiere el literal b) del artículo 421, en la fecha del retiro.

c. En las prestaciones de servicios, en la fecha de emisión de la factura o documento equivalente, o en la fecha de terminación de los servicios o del pago o abono en cuenta, la que fuere anterior.

d. En las importaciones, al tiempo de la nacionalización del bien. En este caso, el impuesto se liquidará y pagará conjuntamente con la liquidación y pago de los derechos de aduana.

(...)

Así mismo, la Administración Tributaria, mediante el Concepto DIAN 29351 del 10 de noviembre de 2015 hace claridad al respecto de este elemento del hecho generador, así:

Desde la óptica del hecho generador, el impuesto sobre las ventas es de carácter instantáneo y se causa por cada operación sujeta al impuesto, pero para efectos de una adecuada y eficiente administración del impuesto se consagra un período bimestral para presentar las declaraciones tributarias correspondientes. La causación del impuesto hace referencia al hecho jurídico material que da lugar al 
nacimiento de la obligación tributaria. En tal sentido la ley tributaria establece el momento a partir del cual se entiende configurado el hecho generador. En consecuencia, es a partir de dicho momento que el mismo debe ser registrado en la contabilidad y declarado. ... La causación del IVA establece el momento en que surge la obligación del afectado económico de cancelar el valor del impuesto conjuntamente con el precio de la transacción. Es de recordar que dentro del precio del bien o del servicio sujeto al IVA, se entiende incluido el impuesto.

En virtud de lo cual se puede percibir que el momento de causación del impuesto sobre las ventas y, por tanto, el perfeccionamiento del hecho generador del mismo en el licenciamiento de intangibles realizado por las sociedades extranjeras proveedoras de streaming en el territorio nacional se daría en el momento de la emisión de la factura o documento equivalente, la cual es previa al pago o abono en cuenta.

De igual forma, dentro del hecho generador, es necesario identificar la base gravable sobre la cual recaerá el tributo, como elemento que define el valor del hecho generador y sobre el cual se aplica la tarifa. Al respecto, la normatividad colombiana ha establecido de forma palmaria cómo se determina la base gravable en la venta y prestación de servicios a través de la regla general prevista en el Artículo 447 del Estatuto Tributario, que al tenor cita:

Art. 447. En la venta y prestación de servicios, regla general.

En la venta y prestación de servicios, la base gravable será el valor total de la operación, sea que ésta se realice de contado o a crédito, incluyendo entre otros los gastos directos de financiación ordinaria, extraordinaria, o moratoria, accesorios, acarreos, instalaciones, seguros, comisiones, garantías y demás erogaciones complementarias, aunque se facturen o convengan por separado y aunque, considerados independientemente, no se encuentren sometidos a imposición.

PARÁGRAFO. Sin perjuicio de la causación del impuesto sobre las ventas, cuando los responsables del mismo financien a sus adquirentes o usuarios el pago del impuesto generado por la venta o prestación del servicio, los intereses por la financiación de este impuesto no forman parte de la base gravable.

Por tanto, la base gravable sobre la cual recae la tarifa en el licenciamiento de intangibles realizado por las sociedades extranjeras proveedoras de streaming en el territorio nacional será el valor de la suscripción mensual cancelada por los usuarios de dicha tecnología.

\section{Tarifa}

La tarifa general del IVA se establece en el Artículo 468 del Estatuto Tributario, que cita:

Art. 468. Tarifa general del impuesto sobre las ventas. * -Modificado por la Ley 1819 de 2016 Art. 184. - La tarifa general del impuesto sobre las ventas es del diecinueve por ciento (19\%) salvo las excepciones contempladas en el título V del Libro III del Estatuto Tributario.

Teniendo en cuenta que dentro de las excepciones previstas en los Artículos 468-1, 468-3 y 475 del Estatuto Tributario no se halla el streaming provisto por las sociedades 
extranjeras dentro del territorio nacional, se puede advertir que dichas rentas percibidas por estas sociedades en el territorio nacional se encuentran gravadas con el IVA a la tarifa general del $19 \%$.

\section{Mecanismos de recaudo}

El gobierno nacional, en cumplimiento de la facultad otorgada por el Artículo 366 del Estatuto Tributario, fijó como mecanismo de recaudo anticipado del IVA, la retención en la fuente sobre el impuesto a las ventas, la cual se consagra en el Artículo 437-1 del Estatuto Tributario, el cual indica:

Art. 437-1. Retención en la fuente en el impuesto sobre las ventas. *-Modificado por la Ley 1819 de 2016 Art. 179.

Con el fin de facilitar, acelerar y asegurar el recaudo del impuesto sobre las ventas, se establece la retención en la fuente en este impuesto, la cual deberá practicarse en el momento en que se realice el pago o abono en cuenta, lo que ocurra primero.

La retención será equivalente al quince por ciento $(15 \%)$ del valor del impuesto.

Sin perjuicio de lo dispuesto en el inciso anterior, el Gobierno Nacional podrá disminuir la tarifa de retención en la fuente del impuesto sobre las ventas, para aquellos responsables que en los últimos seis (6) períodos consecutivos hayan arrojado saldos a favor en sus declaraciones de ventas.

*-Modificado-PARÁGRAFO $1^{\circ}$. En el caso de las prestaciones de servicios gravados a que se refiere los numerales 3 y 8 del artículo 437-2 de este Estatuto, la retención será equivalente al ciento por ciento $(100 \%)$ del valor del impuesto.
PARÁGRAFO $2^{\circ}$. En el caso de los bienes a que se refieren los artículos 437-4 y 437-5 de este Estatuto, la retención equivaldrá al ciento por ciento $(100 \%)$ del valor del impuesto.

Como se puede advertir en el Parágrafo 1 del Artículo 437-1, la retención en la fuente del impuesto a las ventas será del $100 \%$ en los pagos o abonos en cuenta realizados por la prestación de servicios gravados a que se refieren los numerales 3 y 8 del Artículo 437-2 del Estatuto Tributario, dentro de los cuales no se contempla el licenciamiento de intangibles, como se categorizan las rentas percibidas por las sociedades extranjeras proveedoras de streaming en el territorio nacional, por tanto, a través del mecanismo de retención en la fuente sobre el impuesto a las ventas que gravaba los ingresos percibidos por estas sociedades, el gobierno nacional solo podrá recaudar el $15 \%$ de dicho tributo, pues el licenciamiento de intangibles contemplado en el Literal b) del Artículo 420 del Estatuto Tributario no quedó contemplado dentro de la retención del 100 $\%$ prevista para los prestadores de servicios desde el exterior, a pesar de ser cobijados con la aplicación de territorialidad subjetiva dada por el parágrafo 3 del Artículo 420 del Estatuto Tributario. Adicionalmente, dicha retención en la fuente podrá ser realizada a los mismos exclusivamente cuando los pagos o abonos en cuenta se realicen a través de tarjeta crédito o débito, según lo previsto en el Artículo 437-2. La citada normatividad enuncia:

Art. 437-2. Agentes de retención en el impuesto sobre las ventas.

Actuarán como agentes retenedores del impuesto sobre las ventas en la adquisición de bienes y servicios gravados: 
(...)

* -Numeral Modificado por la Ley 1819 de 2016 Art. 180.- 3. Las personas del régimen común, que contraten con personas o entidades sin residencia o domicilio en el país la prestación de servicios gravados en el territorio nacional, con relación a los mismos. 5. **** - Adicionado- Las entidades emisoras de tarjetas crédito y débito y sus asociaciones, en el momento del correspondiente pago o abono en cuenta a las personas o establecimientos afiliados. El valor del impuesto no hará parte de la base para determinar las comisiones percibidas por la utilización de las tarjetas débito y crédito

Cuando los pagos o abonos en cuenta en favor de las personas o establecimientos afiliados a los sistemas de tarjetas de crédito o débito se realicen por intermedio de las entidades adquirentes o pagadoras, la retención en la fuente deberá ser practicada por dichas entidades

8. ** -Numeral adicionado por la Ley 1819 de 2016 Art. 180. - Las entidades emisoras de tarjetas crédito y débito, los vendedores de tarjetas prepago, los recaudadores de efectivo a cargo de terceros, y los demás que designe la Dirección de Impuesto y Aduanas Nacionales -DIAN- en el momento del correspondiente pago o abono en cuenta a los prestadores desde el exterior, de los siguientes servicios electrónicos o digitales: a. Suministro de servicios audiovisuales (entre otros, de música, videos, películas y juegos de cualquier tipo, así como la radiodifusión de cualquier tipo de evento).

b. Servicio de plataforma de distribución digital de aplicaciones móviles.

c. Suministro de servicios de publicidad online.

d. Suministro de enseñanza o entrenamiento a distancia.
(..)

*** -Parágrafo adicionado- PARÁGRAFO TRANSITORIO. El sistema de retención previsto en el numeral 8 del este artículo, empezará a regir dentro de los 18 meses siguientes a la entrada en vigencia de esta Ley, siempre y cuando los prestadores de los servicios a que se refiere el Parágrafo $2^{\circ}$ del artículo 437 incumplan las obligaciones allí previstas.

La Dirección de Impuestos y Aduanas Nacionales mediante Resolución indicará de manera taxativa el listado de prestadores desde el exterior a los que deberá practicárseles la retención prevista en el numeral octavo.

Vale la pena citar que la retención en la fuente prevista en el numeral 5 del Artículo 437-2 del Estatuto Tributario, fue reglamentada en los Decretos 406 y 556 de 2001, compilados en el Artículo 1.3.2.1.7 del Decreto Único Reglamentario 1625 de 2016, que indica:

Artículo 1.3.2.1.7. Retención del impuesto sobre las ventas en operaciones con tarjetas de crédito o débito. Para efectos de la retención en la fuente del impuesto sobre las ventas por parte de las entidades emisoras de las tarjetas de crédito y/o débito y sus asociaciones, o de las entidades adquirentes o pagadoras, el afiliado deberá discriminar en el soporte de la operación el valor correspondiente al impuesto sobre las ventas de la respectiva operación.

Las entidades emisoras de las tarjetas crédito o débito, sus asociaciones, entidades adquirentes o pagadoras efectuarán en todos los casos retención del impuesto sobre las ventas generado en la venta de bienes o prestación de servicios. 
De igual manera, en el Artículo 1.3.2.1.6 del Decreto Único Reglamentario 1625 de 2016, se fijaba una tarifa única de retención en la fuente del impuesto sobre las ventas, así:

Artículo 1.3.2.1.6. Tarifas únicas de retención del impuesto sobre las ventas. La tarifa general de retención del impuesto sobre las ventas es del quince por ciento $(15 \%)$ del valor del impuesto. En la prestación de los servicios gravados a que se refiere el numeral 3o del artículo 437-2 del Estatuto Tributario, en la venta de los bienes de que trata el artículo 437-4 y en la venta de tabaco a que se refiere el artículo 437-5 del mismo Estatuto, la tarifa aplicable será del ciento por ciento $(100 \%)$ del valor del impuesto.

Teniendo en cuenta lo citado en los párrafos anteriores y partiendo de las cifras presentadas por el Departamento Nacional de Planeación - DNP en el foro "El futuro del sector audiovisual en el mercado de la convergencia tecnológica en Colombia"26, en las cuales enuncia algunos de los ingresos percibidos por las sociedades extranjeras no residentes en Colombia por suscripciones de streaming de usuarios residentes y/o domiciliados en el país para el año 2015, es relevante calcular el monto del IVA que se podría recaudar aplicando la retención en la fuente por IVA prevista por el Artículo 437-1 del Estatuto Tributario en concordancia con el numeral 5 del Artículo 437-2 del Estatuto Tributario, y compararlo con el valor total de impuesto al valor agregado que se podría recaudar sobre los ingresos de las sociedades extranjeras proveedoras de streaming en Colombia, cuyos ingresos no fueron cobijados con la retención en la fuente por IVA del $100 \%$ prevista para los prestadores de servicios desde el exterior, sobre quienes recae la aplicación de la territorialidad subjetiva, prevista en el parágrafo 3 del Artículo 420 del Estatuto Tributario, a pesar de que la misma resulta ser extensiva a los ingresos percibidos por el licenciamiento de intangibles de propiedad industrial realizado por sociedades extranjeras en el territorio colombiano, categorización esta que reviste los ingresos percibidos por las sociedades extranjeras proveedoras de streaming, según lo esbozado en el título C del aparte I del capítulo 1 de este texto (véase tabla 6).

De lo anterior, se evidencia que por un vacío normativo, al no hacer extensible la aplicación de la retención en la fuente del $100 \%$ sobre el IVA generado en las transacciones de licenciamiento de la tecnología de streaming realizadas por las sociedades extranjeras en el territorio colombiano, a pesar de estar cobijados dichos ingresos con el principio de territorialidad subjetiva igualmente aplicado a los ingresos de los prestadores de servicios desde el exterior, el país estaría dejando de recaudar 2.088.957 millones de pesos del Impuesto sobre las ventas, calculado solo sobre el ingreso de algunas sociedades proveedoras de streaming a partir de los datos detallados en la tabla 5 extraídos del informe presentado por ${ }^{26}$ Recuperado de: https://www.dnp.gov.co/Paginas/DNP-propone-revolc\%C3\%B3n-en-
regulaci\%C3\%B3n-TIC-y-audiovisual-en-Colombia.aspx 
Tabla 6.

Cálculo de Impuesto al valor agregado retenido estimado sobre valor total de suscripciones de streaming colocadas por Netflix e iTunes

\begin{tabular}{|c|c|c|c|c|}
\hline $\begin{array}{l}\text { Proveedor de } \\
\text { streaming }\end{array}$ & $\begin{array}{c}\text { Valor } \\
\text { suscripciones } \\
\text { aproximado } 2015 \\
\text { (valores en } \\
\text { millones de pesos) }\end{array}$ & $\begin{array}{c}\text { Valor impuesto al va- } \\
\text { lor agregado retenido } \\
\text { bajo la concepción de } \\
\text { pagos con tarjeta de } \\
\text { crédito y tarjeta debito } \\
\text { Tarifa del } 15 \% \\
\text { (Valores en millones de } \\
\text { pesos) }\end{array}$ & $\begin{array}{c}\text { Valor impuesto al valor } \\
\text { agregado retenido bajo } \\
\text { la concepción de pagos a } \\
\text { proveedores extranjeros } \\
\text { bajo criterio de territoria- } \\
\text { lidad subjetiva (parágrafo } \\
3 \text { Art. } 437-2 \text { E.T.) Tarifa } \\
\text { del } 100 \% \\
\text { (valores en millones de } \\
\text { pesos) }\end{array}$ & $\begin{array}{c}\text { Impuesto } \\
\text { dejado de } \\
\text { recaudar por } \\
\text { vacío } \\
\text { normativo } \\
\text { (valores en } \\
\text { millones de } \\
\text { pesos) }\end{array}$ \\
\hline Netflix & 145.726 & 4.153 & 27.688 & 23.535 \\
\hline iTunes & 12.788 .992 & 364.486 & 2.429 .908 & 2.065 .422 \\
\hline
\end{tabular}

* 66,1 \% de 70 millones de dólares, calculados a partir del TRM a 31-12-2015 \$3.149,47

** $1,6 \%$ del PIB de 2015

Fuente: Elaboración propia a partir de los datos presentados por DNP en el foro "El futuro del sector audiovisual en el marco de la convergencia tecnológica en Colombia

el DNP en el foro referenciado, sin tener en cuenta las suscripciones de otros proveedores de streaming representativos como Spotify y Hulu, entre otros. Por tanto, es necesario que Colombia, mediante Decreto reglamentario, extienda la retención del $100 \%$ también a las sociedades que licencian intangibles desde el exterior, pues es claro que estas sociedades voluntariamente no van a acceder a cumplir el deber formal de cobrar, declarar y pagar ese tributo en el territorio nacional, y por tanto se tendrá que dar aplicación a la retención en la fuente como mecanismo de recaudo de este impuesto.

Vale la pena resaltar que el legislativo, en el momento de concebir la legislación prevista en la reforma tributaria introducida mediante la Ley 1819 de 2016, por la cual gravó los ingresos de las sociedades extranjeras que proveen streaming en el territorio con el IVA, brindó a estas el acceso voluntario para inscribirse como responsables de dicho tributo y contribuir con el mismo en
Colombia, respecto a lo cual, en el desarrollo de la investigación realizada, se evidencian algunas buenas prácticas tomadas en otras jurisdicciones a fin de facilitar dicho acceso, y las cuales, a continuación, se apropian como recomendación para ser impulsadas en Colombia:

\section{a) Inscripción en el Registro Único}

Tributario como responsables del Impuesto sobre las ventas.

En este sentido, se considera necesario que los sistemas informáticos de la Dirección de Impuestos y Aduanas Nacionales - DIAN permitan el diligenciamiento en línea de dicho registro, el cual se adecue para este tipo de sociedades y se conforme en un formulario básico y amigable que permita registrar la información general y adquirir las responsabilidades correspondientes, facilitando adjuntar vía electrónica los documentos respectivos que acrediten la constitución y la representación legal. El formulario se ubicará en un micrositio dentro de la página web de la DIAN, 
de fácil visualización y acceso directo, y en el que adicionalmente se le brindará la información necesaria para el cumplimiento de las obligaciones tributarias que le revisten, el cual debe ser desarrollado en el idioma local (español) y en el lenguaje universal (inglés).

\section{b) Cumplimiento de obligaciones tributarias.}

Acompañamiento constante por parte de la administración tributaria a las sociedades extranjeras proveedoras de streaming que les facilite el cumplimiento de sus obligaciones, así como impulsar en la Comunidad Andina - CAN la creación de una ventanilla única similar a la establecida en la unión europea respecto a los impuestos indirectos, y mediante la cual las sociedades extranjeras, con una sola inscripción como responsables, puede cumplir sus obligaciones tributarias en toda la comunidad de países.

\section{V.Aplicación del Impuesto de Renta e Im- puesto al Valor Agregado - IVA sobre los in- gresos percibidos por Netflix en Colombia}

\section{A. Netflix como sociedad inmersa en la Economía digital}

Netflix es la compañía de video y cine online por demanda bajo streaming número uno en el mundo. Inició su operación en 1997 en California, Estados Unidos, con un videoclub online doméstico de alquiler de DVD. En 2007 ingresa al negocio de streaming doméstico y, finalmente, en 2011 expande la operación de streaming a nivel internacional, penetrando inicialmente Latinoamérica y el Caribe, completando su penetración en todo el mundo en el año 2016, buscando con esta estrategia de negocio disminuir la piratería de la industria audiovisual (Netflix.com, s.f.).
Con esta estrategia de negocio, Netflix es pionera y encabeza la innovación en los contenidos digitales con más de 100 millones de suscriptores en más de 190 países, y actualmente es la cadena de streaming de contenidos digitales líder en el mundo, a través de la cual es posible disfrutar de más de 125 millones de horas de series y películas al día, cuando se quiera, donde se quiera y desde cualquier pantalla conectada a Internet, permitiéndoles a sus suscriptores reproducir, pausar o continuar disfrutando en cualquier momento, todo ello sin anuncios ni compromisos de permanencia (Netflix.com, s.f.)

En 2017 alcanza un total de 99 millones de usuarios, y registra unos ingresos totales a cierre de 2016 de US $\$ 8.831$ millones.

Del total de ingresos recibidos por Netflix, el $62,5 \%$ son provistos por el negocio de streaming doméstico y el $22,9 \%$ por el negocio de streaming internacional, generando una utilidad neta de 3,55\% para el trimestre 4 de 2016, siendo afectado por impuestos en un $0,45 \%$, teniendo una rentabilidad antes de impuesto del $4 \%$, lo cual prevé un margen de tributación bajo respecto al presentado por la industria audiovisual, que es del 5,51\%, en la cual posee una participación del $40 \%$.

Como ya se mencionó, el streaming es un negocio básicamente $100 \%$ desarrollado en el comercio electrónico, bajo la modalidad B2C - business-to-consumer, por tanto, su contratación es electrónica. Claramente, Netflix no es ajeno a ello; su negocio es netamente desarrollado bajo el modelo de negocio de comercio electrónico, y es un modelo de ingresos de concesión de licencias sobre contenidos y tecnología, según lo advertido de la lectura y análisis de los términos de uso 


\section{Ilustración 13.}

Países con acceso a Netflix en 2017

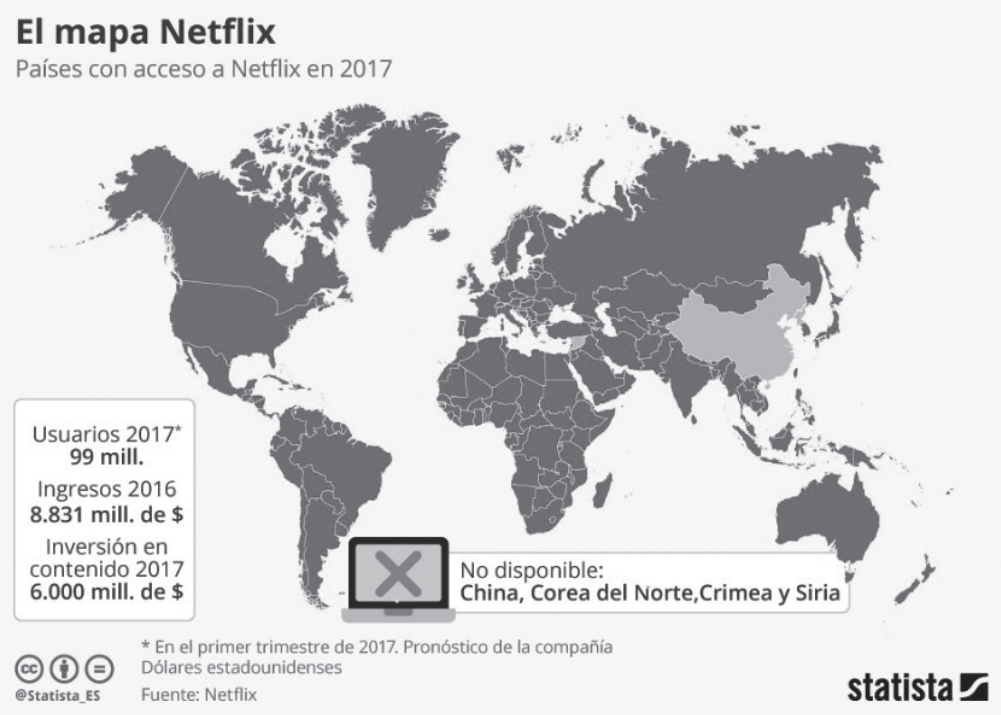

Fuente: Neflix

Ilustración 14.

Ingresos netos de Netflix entre 2000 y 2016 (en millones US \$)

\section{Netflix supera las expectativas}

Ingresos netos de Netflix entre 2000 y el tercer trimestre de 2016 (en mill. \$)

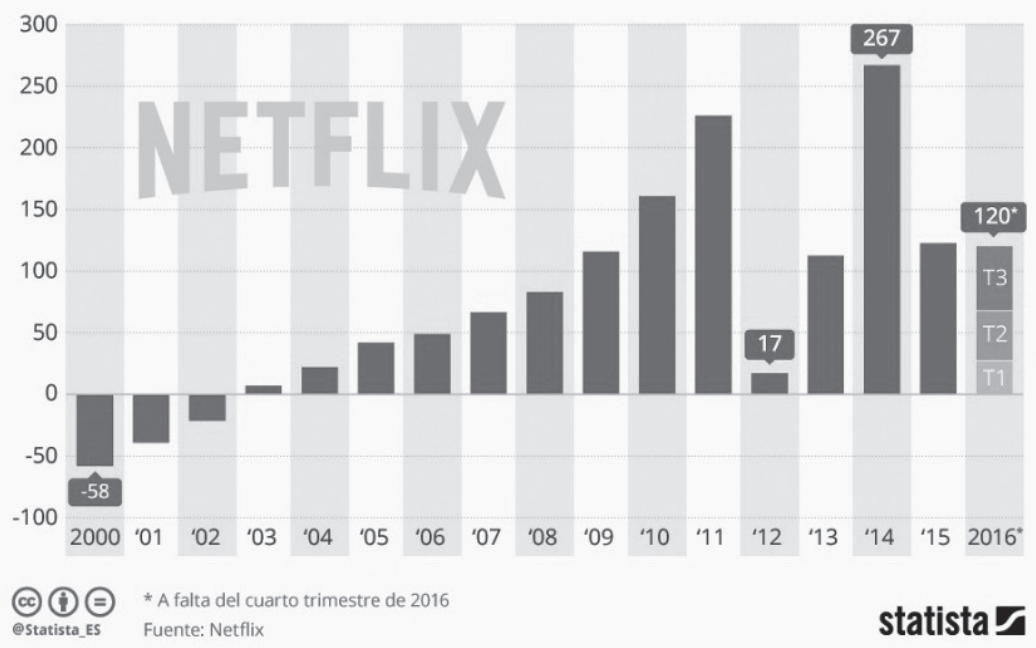

Fuente: Neflix 


\section{Ilustración 15. \\ Márgenes de rentabilidad Netflix}

Rentabilidad: TTM vs Margen Promedio de 5 Años

$\operatorname{TTM}(\%)$

Promedio de 5 Años (\%)

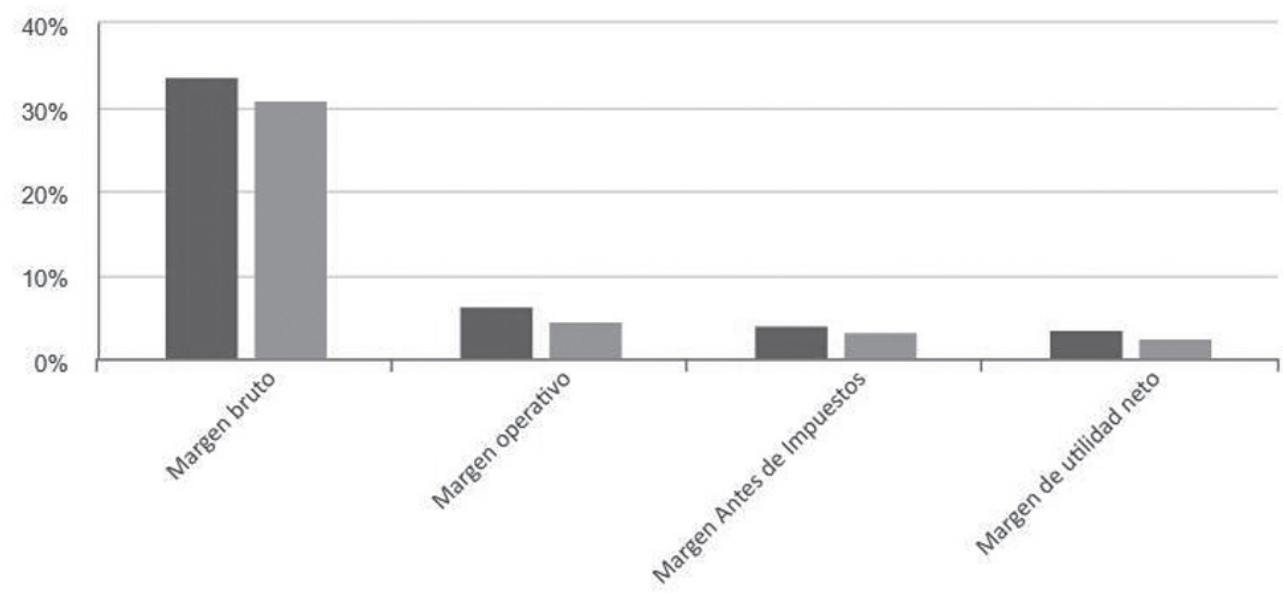

Margen bruto TTM

$33,79 \%$

$48,7 \%$

Margen bruto 5YA

$30,78 \%$

$47,14 \%$

Margen operativo TTM

$6,33 \%$

$17,41 \%$

Margen operativo 5YA

$4,61 \%$

$17,75 \%$

Margen Antes de Impuestos TTM

$4 \%$

$14,23 \%$

Margen Antes de Impuestos 5YA

$3,28 \%$

$14,63 \%$

Margen de utilidad neto TTM

$3,55 \%$

$8,72 \%$

Margen de utilidad neto $5 Y \mathrm{~A}$

$2,43 \%$

$9,98 \%$

Fuente: https://es.investing.com/equities/netflix,-inc.-ratios.

de la membresía de Netflix, que suscriben los usuarios al adquirirla. Igualmente, de su lectura se identifica que Netflix posee una distribución de las suscripciones en diferentes filiales ubicadas en disímiles países así:

- Usuarios Brasil: suscriben membresía con Netflix Entretenimiento Brasil Ltda., ubicada en Paraíso, estado de Santa Catarina de Brasil.

- Usuarios Japón: suscriben membresía con Netflix K.K., ubicada en Tokio, Japón.

- Usuarios Corea: suscriben membresía con Netflix Services Korea Ltd, ubicada en Seúl, Corea.
- Usuarios Estados Unidos: suscriben membresía con Netflix Inc., ubicada en Los Gatos, estado de California, Estados Unidos.

- Usuarios India: suscriben membresía con Netflix Entertainment Services India LL.P, ubicada en Maharashtra, India.

- Usuarios demás países: suscriben membresía con Netflix International B.V., sociedad de responsabilidad limitada ubicada en Ámsterdam, Países Bajos (Netflix.com, s.f.).

Por tanto, cada uno de estos países resulta ser el domicilio de Netflix en la contratación del streaming, y la ley aplicable sobre esta 


\section{Ilustración 16.}

Ganancias y pérdidas mensuales de Netflix por usuarios en dólares

\section{El mercado internacional no es rentable para Netflix}

Ganancias y pérdidas mensuales de Netflix por usuario en dólares

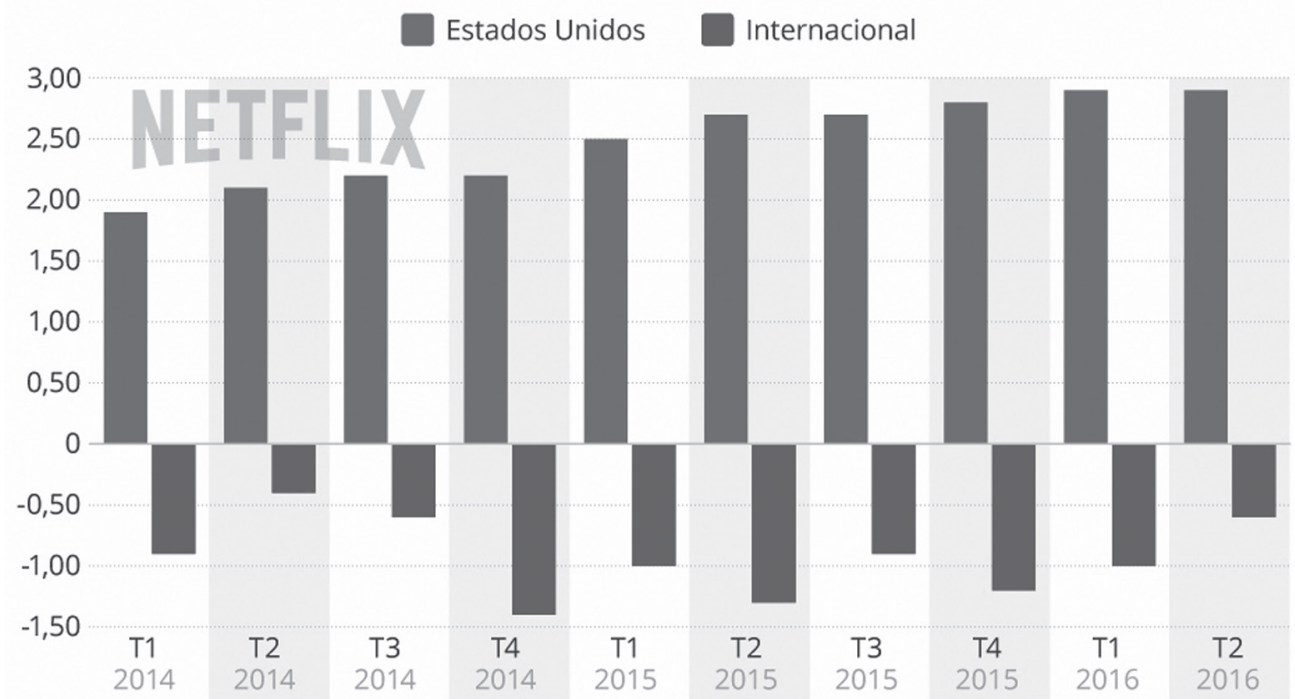

(c) (i) $€$

@Statista_ES Fuentes: Statista Digital Market Outlook, Netflix

\section{statista}

Fuente:

contratación es la ley vigente en cada uno de los Estados referidos. Esta diversidad de domicilios obedece a la utilización que Netflix realiza de la red de servidores de Amazon Web Services (en adelante AWs), como proveedor de servicios de computación en la nube, $\mathrm{y}$ los cuales le permitieron extender una verdadera red global de contenidos de video en internet, ya que AWS cuenta con diferentes regiones cloud (aws.amazon.com, s.f.).

Así mismo, a fin de que el streaming sea más ágil, Netflix implementó la red de distribución de contenido Netflix Open Connect, mediante alianzas con los Proveedores de Servicios de Internet (en adelante ISP), con las cuales logra localizar en sus centros de datos los dispositivos Open Connect Integrado ( en adelante OCA), en los cuales precarga sus contenidos de acuerdo con la ubicación del ISP, y actúa como un buffer que precarga el contenido agilizando su visualización para el usuario final, lo cual podría constituir un centro de alojamiento de contenidos de Netflix en cada uno de los países en los que los ISP poseen centros de datos.

Una vez definido el negocio ejecutado por Netflix y la forma de su contratación, es relevante esbozar la forma en que se recepcionan los pagos por Netflix a nivel mundial, entre los cuales se tiene, según lo descrito en la página web de esta sociedad proveedora de streaming: 


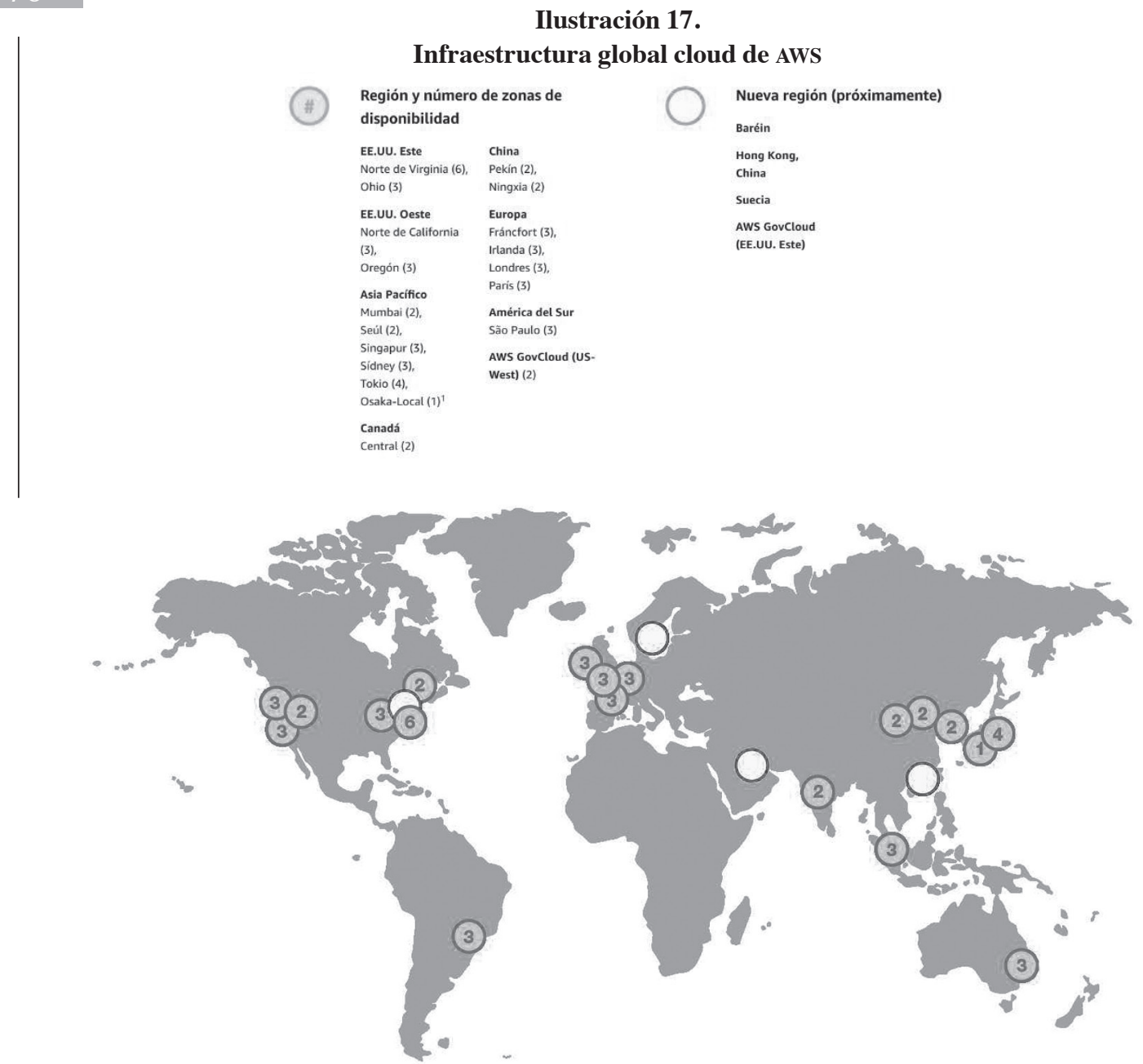

Fuente: https://aws.amazon.com/es/about-aws/global-infrastructure/.

- Tarjetas de crédito y débito (Visa, MasterCard, American Express y Diners) emitidas para uso local y habilitadas para transacciones de comercio electrónico.

- Tarjetas prepagas (Visa, MasterCard o American Express).

- Tarjetas de regalo de Netflix disponibles en varios comercios minoristas.
- iTunes para Apple TV o modelos iPhone, iPad o iPod Touch con iOS 7.0 o superior.

- Google Play (Netflix 2017).

\section{B. Hecho generador de impuestos directos e indirectos para Netflix en Colombia}

Como se ha mencionado en los apartes anteriores, Netflix es una de las sociedades 
Ilustración 18.

Ubicaciones OCCA de Netflix

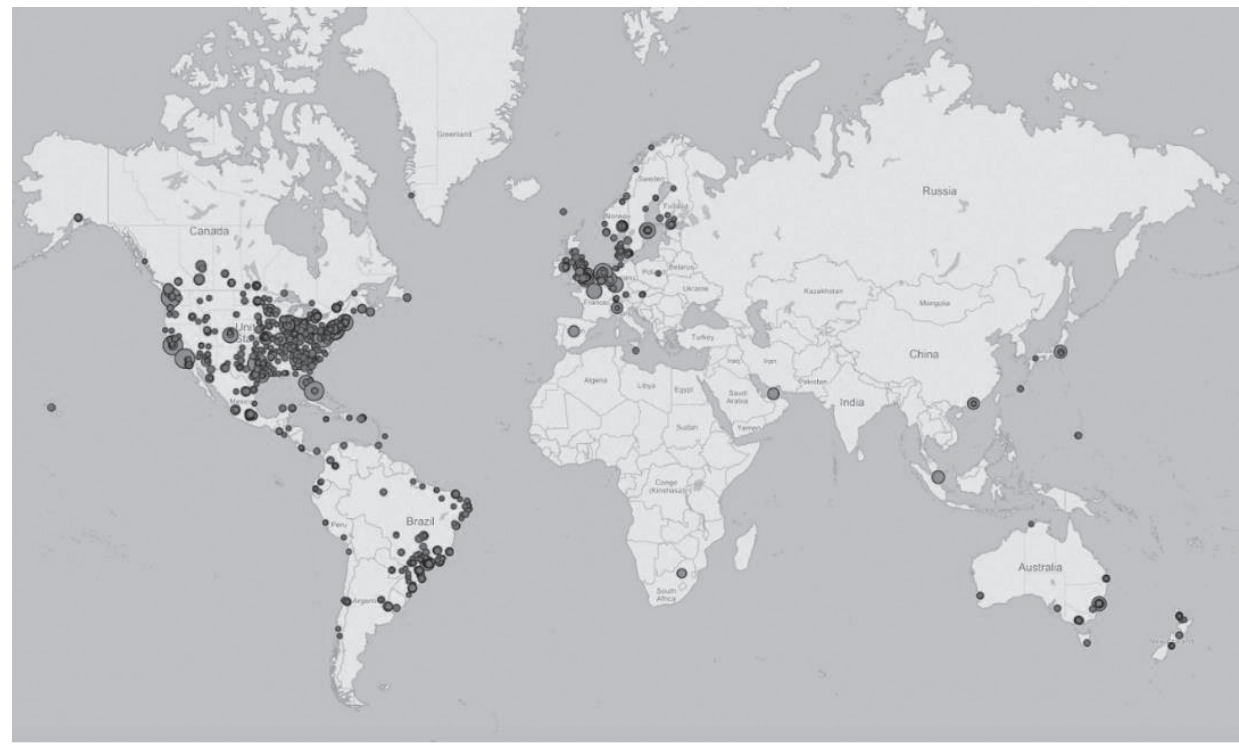

Ubicaciones de los proveedores de servicios de Internet

$\square$ Punto de intercambio de Internet (el tamaño de los círculos refleja el volumen)

Fuente: https://media.netflix.com/es_es/company-blog/how-netflix-works-with-isps-around-the-globe-to-deliver-agreat-viewing-experience.

Ilustración 19.

Flujo de los contenidos de Netflix hasta el usuario final
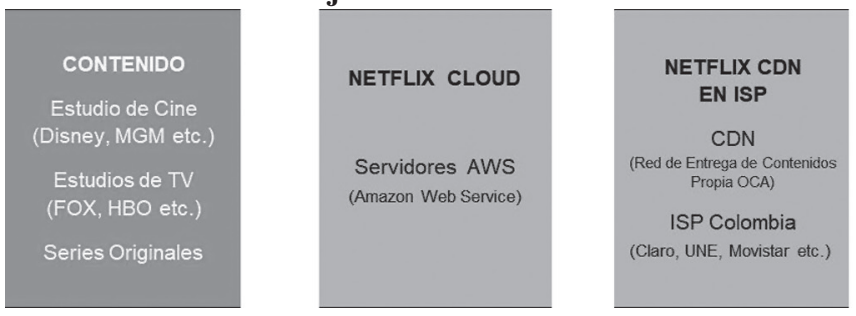

\begin{tabular}{|ll}
$T$ & \\
E & $S$ \\
C & $T$ \\
N & $R$ \\
O & $E$ \\
L & $A$ \\
$O$ & $M$ \\
O & $I$ \\
G & $N$ \\
I & C \\
A & \\
\hline
\end{tabular}

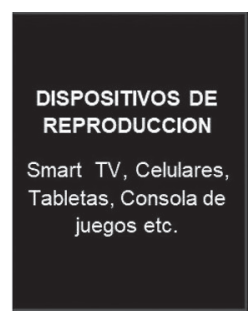

Fuente: Elaboración propia a partir de información de help.netflix.com.

extranjeras no residentes en Colombia que provee streaming en el territorio nacional. Por tanto, como se determinó en el aparte II del Capítulo 2, las rentas percibidas por Netflix en Colombia se consideran ingresos de fuente nacional, clasificados como regalías por explotación de la tecnología de streaming considerada propiedad industrial, y por tanto las mismas constituyen hecho generador del impuesto de renta (impuesto directo) en Colombia. 
Así mismo, en el aparte II del Capítulo 3 se identifica que las rentas percibidas por las sociedades extranjeras proveedoras de streaming en el territorio nacional, incluida Netflix, se encuentran gravadas con el impuesto sobre las ventas (impuesto indirecto), pues estas son categorizadas como regalías percibidas por el licenciamiento de la tecnología de streaming, lo cual, según el parágrafo 3 del Artículo 420 del Estatuto Tributario, resulta ser hecho generador del impuesto sobre las ventas en Colombia.

Teniendo en cuenta que el presupuesto fáctico del hecho generador del impuesto sobre las ventas es el momento de causación del mismo, conforme lo previsto en el Artículo 429 del Estatuto Tributario, en concordancia con el Concepto DIAN 29351 de 2015, en el licenciamiento de la tecnología de streaming realizado por la sociedad extranjera Netflix en el territorio nacional, se puede precisar que dicho licenciamiento es continuo, ya que el suscriptor puede usar en el momento que desee dicha tecnología para acceder a contenido ilimitado de carácter digital desde casi cualquier tipo de dispositivo que tenga acceso a internet y, teniendo en cuenta la Administración Tributaria colombiana, no posee tecnología o infraestructura por parte de la administración tributaria para gravar con el impuesto sobre las ventas cada descarga realizada, y ciñéndose a lo previsto en la normatividad mentada respecto a la primacía del evento que cause el impuesto, el legislador, con base en las sugerencias de la OCDE propuestas en la Acción 1 BEPS y expuestas en el primer capítulo de este trabajo, determinó que el momento de causación del impuesto sobre las ventas en el licenciamiento de la tecnología de streaming realizado por las sociedades extranjeras en el territorio nacional, es con la generación de la factura o documento equivalente, pues es claro que la misma se genera previo al pago, como se puede apreciar en las siguientes ilustraciones de la factura y pago del servicio de Netflix de un usuario en Colombia.

Así mismo, es necesario determinar la base gravable sobre la cual recaerá el impuesto sobre las ventas en el licenciamiento de la tecnología de streaming realizada por Netflix en Colombia, pues esta constituye uno de los elementos fundamentales del hecho generador, ya que la misma puntualiza el valor del mismo, y constituye el monto sobre el cual recaerá la tarifa del impuesto; por tanto, partiendo de lo previsto en el Artículo 447 del Estatuto Tributario, se identifica que dicho monto está constituido por el valor mensual de suscripción cancelado por los usuarios según la membresía tomada.

\section{Tarifa de impuestos directos $e$ indirectos para Netflix en Colombia}

La tarifa del impuesto de renta (impuesto directo) aplicable a los ingresos percibidos por Netflix en Colombia como sociedad extranjera que provee streaming en el territorio nacional, es la tarifa general prevista en el Artículo 240 del Estatuto Tributario, la cual asciende al $33 \%$ de las rentas susceptibles de incrementar el patrimonio de la sociedad.

En cuanto a la tarifa del IVA (Impuesto indirecto), con la cual se gravarán los ingresos percibidos por Netflix en Colombia a raíz de las transacciones realizadas al proveer streaming en el territorio nacional, será la tarifa general del $19 \%$, según lo previsto en el Artículo 468 del Estatuto Tributario, pues las rentas por licenciamiento de intangibles, 
Ilustración 20.

Factura emitida por Netflix

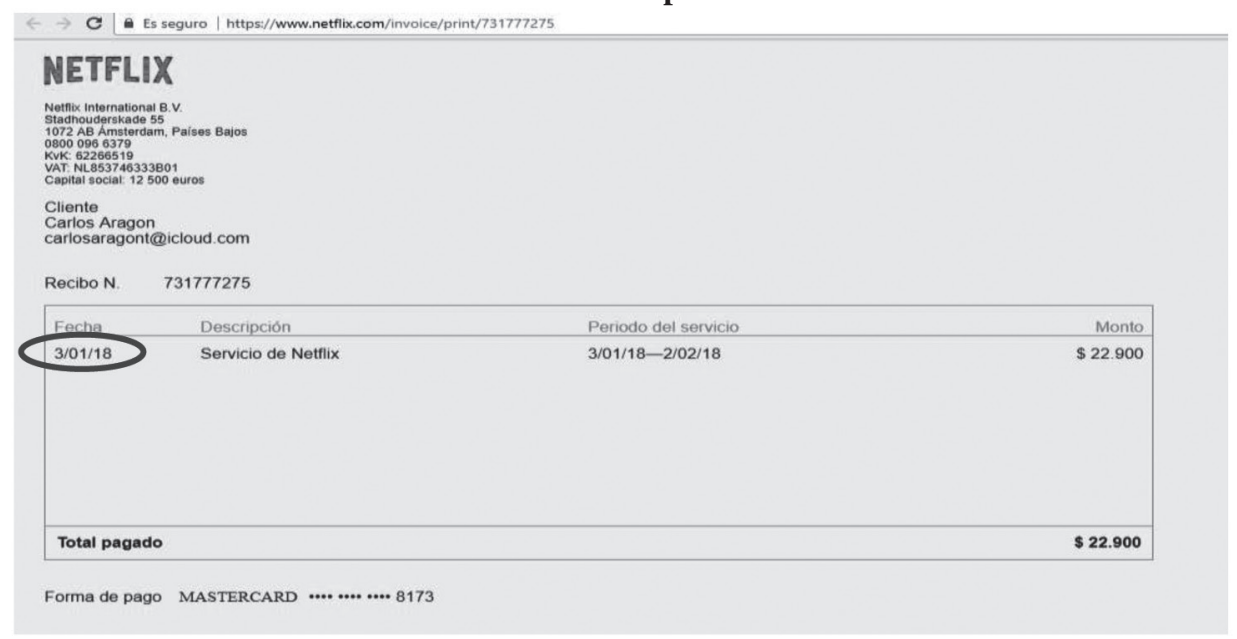

Fuente: Elaboración propia a partir de la factura emitida por Netflix a usuario en Colombia.

Ilustración 21.

Pago factura Netflix

\begin{tabular}{|c|c|c|c|c|c|c|c|c|c|}
\hline \multicolumn{10}{|c|}{ DETALLE DE TRANSACCIONES } \\
\hline $\begin{array}{c}\text { Fechr } \\
\text { (DD/MM/AA) }\end{array}$ & $\begin{array}{c}\text { Número } \\
\text { Comprobsnte }\end{array}$ & Descripcoín & $\begin{array}{l}\text { Vilorde } \\
\text { transection }\end{array}$ & $\begin{array}{l}\text { Grgosy } \\
\text { ibonos }\end{array}$ & $\begin{array}{l}\text { Grigo } \\
\text { :Gapital }\end{array}$ & Cuots: & $\begin{array}{c}\text { Soldo } \\
\text { perdiente } \\
\text { por frcturn }\end{array}$ & $\begin{array}{l}\text { Ths } \\
\text { M.V }\end{array}$ & $\begin{array}{l}\text { Tag } \\
\text { E.A }\end{array}$ \\
\hline $19 / 01 / 18$ & & $\begin{array}{l}\text { 8173 CARLOS HUMBETO } \\
4 \text { X100OSALOD PWWOR }\end{array}$ & 50 & $\$ 113$ & st & ode 0 & & $0,0,0 \%$ & $0,00 \%$ \\
\hline $19 / 01 / 18$ & & COOTA DE MANEO & 50 & $\$ 74.400$ & th & Ode 0 & & $00,00 \%$ & $0,00 \%$ \\
\hline $04 / 01 / 18$ & & PAGORECOBDO EN OFCNA & 50 & $\$ 1.24000$ & $\$$ & Ode 0 & & $00,00 \%$ & $0,00 k$ \\
\hline $04 / 01 / 18$ & 80736 & CANCELADA PAYU'NETIXIX & $\$ 22.900$ & $\$ 0$ & \$t & Ode 1 & & $02,27 \%$ & 30,112 \\
\hline
\end{tabular}

Fuente: Extracto Tarjeta Master Card usuario Netflix en Colombia

contemplados dentro de estos la tecnología de streaming como propiedad intelectual, no se encuentran exceptuadas en las tarifas diferenciales fijadas en los Artículos 468-1, 468-3 y 475 .

\section{Mecanismos de recaudo de los \\ impuestos directos e indirectos para Netflix en Colombia}

Como se mencionó en el aparte IV de los Capítulos 2 y 3 de este texto, el gobierno 
nacional, en virtud de la facultad prevista en el Artículo 366 del Estatuto Tributario, ha fijado unas retenciones en la fuente como mecanismo anticipado de recaudo de los tributos. En vista de ello, los mecanismos de recaudo aplicables a los impuestos directos e indirectos que gravan las rentas percibidas por Netflix en Colombia al proveer streaming en el territorio nacional son:

\section{Impuestos directos}

En virtud de lo anterior, a Netflix en Colombia le es aplicable la retención en la fuente prevista en el Artículo 408 del Estatuto Tributario, que fija la retención en la fuente a los pagos al exterior por concepto de regalías como mecanismo de recaudo del impuesto de renta que deben tributar las sociedades extranjeras no residentes en el país por las rentas percibidas en el territorio nacional y constitutivas de ingresos de fuente nacional. Dicha retención asciende al $15 \%$ de los pagos o abonos en cuenta que se realicen en efectivo, giro directo o transferencia bancaria a favor de las sociedades extranjeras no residentes en Colombia, por parte de los terceros que ostenten la calidad de agentes de retención según lo previsto en el Artículo 368 y 368-2 del Estatuto Tributario ${ }^{27}$, que al tenor indica:

Art. 368. Quiénes son agentes de retención. Son agentes de retención ... las demás personas naturales o jurídicas.

Art. 368-2. Personas naturales que son agentes de retención.... Personas naturales que tengan la calidad de comerciantes y que en el año inmediatamente anterior tuvieran un patrimonio bruto o unos ingresos brutos superiores a 30.000 UVT (UVT $2018 \$ 33.156$; $\$ 994.680 .000$ )

Es decir, retenciones en la fuente que resultan aplicables en las transacciones bajo la modalidad de comercio electrónico B2B dadas entre comerciantes que distribuyen streaming de Netflix y las sociedades extranjeras no residentes Netflix que proveen streaming en el territorio nacional, transacciones estas que solo poseen un nivel de participación en el mercado colombiano del $10 \%$.

Ahora bien, para los pagos realizados a través de tarjetas crédito, tarjetas débito y pasarelas o servicios de pago (PayU, pagos onli$n e$, entre otros), se aplica la tarifa de retención prevista en los Artículos 1.3.2.1.8 y 1.3.2.1.2 del Decreto Único Reglamentario 1625 de 2016, equivalente al 1,5\% de los pagos o abonos en cuenta realizados con estos medios de pago, siempre y cuando las tarjetas crédito y débito utilizadas en las transacciones hayan sido emitidas por entidades emisoras residentes en el territorio nacional, retención esta que resulta aplicable en las transacciones B2C en las cuales Netflix sociedad extranjera no residente en Colombia contrata streaming directamente con el usuario final, y con quien en el acuerdo de licencia pacta el pago anticipado a través de estos medios de pago, modalidad de contratación que cobija el $90 \%$ de las suscripciones de esta tecnología en el territorio nacional.

Por otra parte, vale la pena aclarar que la retención por pagos a través de las tarjetas crédito o tarjetas débito es practicada por las

${ }^{27}$ Decreto 624 de 1989. 
entidades emisoras de dichos medios de pago domiciliadas en Colombia en el momento del abono del pago a los establecimientos afiliados, según lo preceptuado en el Artículo 1.3.2.1.8 y 1.3.2.1.2 del Decreto Único Reglamentario 1625 de 2016.

Así mismo, es relevante citar lo previsto en la doctrina emitida por la Administración Tributaria, lo que sucede en el caso en que los pagos con tarjeta crédito o tarjeta débito se realicen por un agente de retención fijado en el Artículo 368 y 368-2 del Estatuto Tributario, pues ha indicado la administración tributaria ${ }^{28}$ que, en estos casos, prima la retención en la fuente prevista en el Artículo 1.3.2.1.8 del Decreto Único Reglamentario 1625 de 2016 sobre las previstas en los Artículos 408 al 415 del Estatuto Tributario, es decir, la tarifa aplicable y el agente de retención que debe practicarla cuando subsisten los dos agentes de retención en una misma transacción y los pagos se realizan con tarjeta crédito o tarjeta débito es la tarifa del 1,5\% sobre el valor del pago o abono en cuenta, y el agente de retención es la entidad emisora del medio de pago residente en Colombia.

En atención a lo anterior, se debe comentar que las entidades emisoras de las tarjetas débito y tarjetas crédito que se revisten de la calidad de agentes de retención prevista en el Artículo 1.3.2.1.2 del Decreto Único Reglamentario 1625 de 2016, son las entidades emisoras residentes en Colombia y, por tanto, la retención en la fuente prevista en el Artículo 1.3.2.1.8 del Decreto Único Reglamentario 1625 de 2016 solamente es aplicable cuando la tarjeta crédito o tarjeta débito con la cual se realiza el pago ha sido emitida por una entidad emisora residente en Colombia.

En la actualidad, Netflix maneja los medios de pago previstos anteriormente. A futuro, es viable que incursione en el medio de pago de las criptomonedas, respecto al cual, y teniendo en cuenta el análisis realizado en el aparte II del capítulo 2, la legislación doméstica colombiana podría ser reglamentada e imponer la obligación de agente de retención prevista en el Artículo 1.3.2.1.2 del Decreto Único Reglamentario 1625 de 2016 para las entidades emisoras de tarjetas de crédito y tarjetas débito, a las casas de cambio que emiten las billeteras virtuales, pues, como se indicó en el título mentado en Colombia, ya existe la casa de cambio www.buda.com, operada por la sociedad SurBTC S.A.S., que realiza esta operación de forma similar a la operatividad de las entidades emisoras de tarjeta crédito y tarjeta débito.

Teniendo en cuenta lo anteriormente descrito, se hace necesario evaluar si Colombia posee convenio suscrito y vigente con el Estado de residencia de Netflix para evitar la doble imposición, pues ello restringiría la potestad tributaria de Colombia para gravar las rentas percibidas por esta sociedad en el Estado colombiano, pues, como se analizó en el aparte $\mathrm{V}$ del capítulo 2 de este texto, la calificación dada a estas rentas desde la óptica de los convenios para evitar la doble imposición suscritos por Colombia le otorga potestad tributaria para gravarlas al Estado de fuente con un límite de tarifa del $10 \%$.

${ }^{28}$ Concepto 68810 de 2001, 69307 de 2010 y 34880 de 2010. 
Bajo esta premisa, se hace necesario analizar las diferentes jurisdicciones desde las que opera Netflix, plasmadas en el aparte I del presente capítulo, para determinar desde cuál jurisdicción Netflix provee streaming en Colombia. Al respecto, se puede identificar que Netflix provee el servicio de streaming en Colombia, a través de su filial Netflix International B.V. ubicada en Ámsterdam, Países Bajos, que es la filial mediante la cual provee streaming a nivel mundial excepto en Brasil, Japón, Corea, Estados Unidos e India, por tanto, se puede determinar, según lo citado en el aparte $\mathrm{V}$ del capítulo II de este texto, que Colombia, al no tener suscrito y vigente convenio para evitar la doble imposición con Países Bajos, puede ser gravada con el impuesto sobre la renta y aplicarse la retención por pagos al exterior descrita en el Artículo 408 del Estatuto Tributario sobre las rentas obtenidas por Netflix al proveer streaming en Colombia.

Por otra parte, vale la pena aclarar que a pesar de que las retenciones enunciadas se practiquen de acuerdo con lo previsto en el Artículo 592 del Estatuto Tributario, ello no exime en un $100 \%$ a la sociedad Netflix International B.V. de presentar la declaración del impuesto de renta en Colombia, ya que no se cumple el precepto contemplado en el Numeral 2 del Artículo 592 del Estatuto Tributario, que al tenor cita:

Art. 592. Quiénes no están obligados a declarar. No están obligados a presentar declaración de renta y complementarios:

\section{(1)}

2.Las personas naturales o jurídicas, extranjeras, sin residencia o domicilio en el país, cuando la totalidad de sus ingresos hubieren estado sometidos a la retención en la fuente de que tratan los artículos 407 a 411 , inclusive, y dicha retención en la fuente, así como la retención por remesas*** cuando fuere del caso, les hubiere sido practicada.

Pues, como se acotó anteriormente, el mercado de suscriptores de Netflix en un $90 \%$ transa sus acuerdos de licencia directamente con la sociedad extranjera utilizando como medio de pago tarjetas crédito, tarjetas débito o pasarelas de pago, sobre las cuales se aplicaría la retención en la fuente prevista en el Artículo 1.3.2.1.8 y 1.3.2.1.2 del Decreto Único Reglamentario 1625 de 2016, la cual no exime de la obligación formal de presentar el denuncio rentístico del impuesto de renta a la sociedad extranjera no residente en Colombia, según lo previsto en el Artículo 592 del Estatuto Tributario; por tanto, la sociedad Netflix International B.V. estaría obligada a presentar la declaración del impuesto de renta y complementarios en Colombia, determinando el impuesto respectivo sobre los ingresos de fuente nacional percibidos en el territorio colombiano.

Partiendo de las cifras expresadas en el aparte IV del Capítulo 2 de este texto, es relevante indicar que Netflix en Colombia, a cierre de 2015, percibía ingresos de fuente nacional por valor de $\$ 145.726$ millones $^{29}$, los cuales, al aplicarle la retención prevista

\footnotetext{
${ }^{29}$ Calculados a partir de las cifras presentadas por DNP en el foro "El futuro del sector audiovisual en el marco de la convergencia tecnológica en Colombia (66,1\% de 70 millones de dólares, calculados a partir de la TRM a 31-12-2015 \$3.149,47).
} 
para pagos con tarjeta crédito y tarjeta debito generarían un recaudo del impuesto de renta que grava dichas rentas por valor de $\$ 2.186$ millones, cifra que hoy por hoy se fuga de los ingresos tributarios del país por la falta de aplicación de esta retención en la fuente por parte de las entidades emisoras de tarjeta débito y crédito, previa la directiva respectiva por parte de la Administración Tributaria.

\section{Impuestos indirectos}

Respecto al IVA, que grava las rentas percibidas por Netflix en Colombia, al proveer streaming en el territorio nacional, el gobierno, en el Artículo 437-1 del Estatuto Tributario, ha fijado una retención en la fuente por IVA del $15 \%$, citando en el Artículo 437-2 del Estatuto Tributario a los agentes retenedores que practicarán dicha retención, dentro de los cuales se hallan descritas en el numeral
5 las entidades emisoras de tarjetas crédito y débito, que serán las que practiquen retención en la fuente sobre el IVA generado por Netflix en Colombia, en el momento del pago o abono en cuenta, la cual ascenderá al $15 \%$ del impuesto generado. Vale la pena aclarar al respecto, como se acotó en el aparte anterior, que el mercado de Netflix en Colombia, en un $90 \%$, transa sus pagos a través de tarjetas crédito y/o débito, es decir, que de esta forma se asegura el recaudo anticipado del $15 \%$ del IVA generado en un $90 \%$ de las transacciones realizadas por Netflix en el territorio nacional.

Ahora bien, la retención en la fuente prevista en el Artículo 437-1 del Estatuto Tributario, será plenamente aplicable sobre el IVA generado en las transacciones que Netflix realice y cuyo pago sea a través de tarjeta de

\section{Ilustración 22.}

\section{Funcionamiento de las transacciones realizadas con tarjetas de crédito}

\section{¿Qué es un adquirente?}

También conocido como banco comercial, un

adquirente es una entidad financiera con licencia

de Mastercard ${ }^{t}$ para ayudar a un establecimiento

a cumplir con su obligación de aceptar Mastercard.

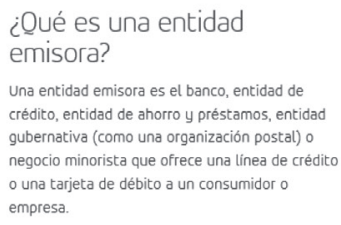

¿Qué es una entidad emisora?

Una entidad emisora es el banco, entidad de crédito, entidad de ahorro y préstamos, entidad gubernativa (como una organización postal) o negocio minorista que ofrece una línea de crédito o una tarjeta de débito a un consumidor o empresa.

\section{¿Qué rol desempeña} Mastercard?

Mastercard no es ni una entidad emisora ni un adquirente. Nuestro papel consiste en proporcionar la tecnología y la red que hacen posibles las transacciones.

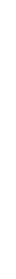


crédito o débito expedida por entidades emisoras residentes en el país, pues es claro que si la tarjeta de crédito o débito utilizada es internacional, la entidad emisora del exterior no estaría obligada a practicar dicha retención, pues no tendría la responsabilidad de ser agente retenedor al no estar domiciliado en Colombia. Sin embargo, es relevante indicar que las transacciones con tarjetas crédito o débito no tendrían una tendencia mayor, toda vez que las comisiones por compras internacionales que tendría que asumir el suscriptor de la tecnología de streaming provista por Netflix será muy superior al valor de la misma suscripción, por tanto, no sería coherente la utilización de este medio de pago.

De igual forma, se contempla que la retención en la fuente fijada en el Artículo 437-1 del Estatuto Tributario, realizada por los entidades emisoras de crédito y débito descritas como agentes retenedores del IVA según lo previsto en el numeral 5 del Artículo 437-2 del Estatuto Tributario, es totalmente aplicable cuando el medio de pago utilizado por los suscriptores de la tecnología de streaming con Netflix sean las pasarelas de pago, pues estos intermediarios actúan a través de contratos de mandato y, por tanto, las retenciones practicadas a estos en el momento del pago o abono en cuenta serán trasladadas al beneficiario efectivo del pago en el momento del traslado del ingreso.

Igualmente, como se acotó en el aparte anterior, en el caso de que Netflix incursionara en el medio de pago de criptomonedas, la retención en la fuente prevista en el Artículo 437-1 del Estatuto Tributario sería aplicable haciendo extensiva mediante la reglamentación necesaria la responsabilidad de agente de retención fijada en el numeral 5 del Artículo 437-2 del Estatuto Tributario para las entidades emisoras de tarjetas crédito y débito, a las casas de cambio que emiten billeteras virtuales, pues la operación de estas es similar y/o idéntica a las entidades emisoras.

Partiendo de las cifras expresadas en el aparte IV del capítulo 3 de este texto, es relevante indicar que Netflix en Colombia, a cierre de 2015, percibía ingresos gravados con el impuesto sobre las ventas por

\section{Ilustración 23.}

Funcionamiento de una Pasarela de Pagos
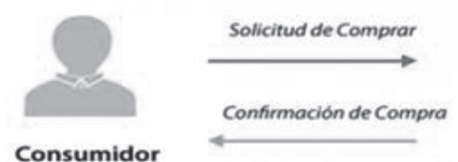

Consumidor

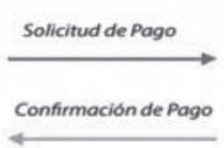

Transeferncia de Pago
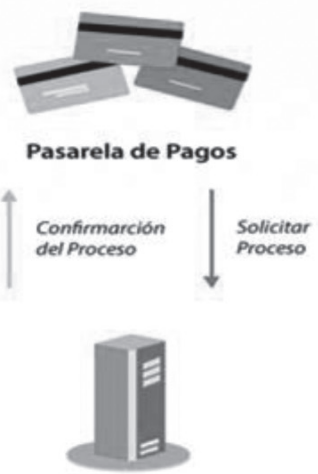

Procesador de Pagos

Fuente: https://www.actualidadecommerce.com/que-es-y-como-funciona-la-pasarela-de-pago-en-ecommerce/. 


\section{Ilustración 24.}

Funcionamiento de las Criptomonedas

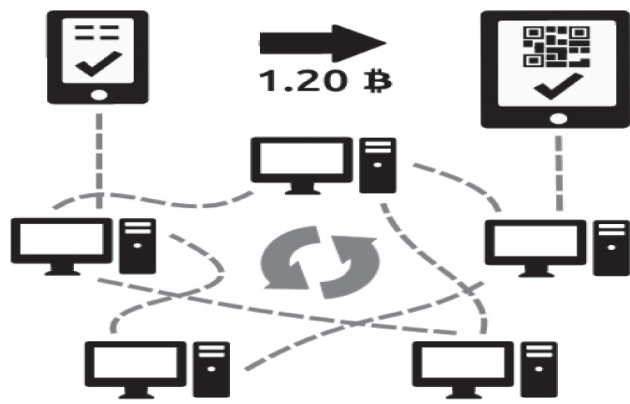

Fuente: Recuperado de (https://bitcoin.org/es/como-funciona)

valor de $\$ 145.726$ millones $^{30}$, los cuales, al aplicarles la tarifa del IVA vigente para ese año, que era del $16 \%$, se puede citar que Netflix generó IVA para el año gravable 2015 por valor de $\$ 23.316$, que al aplicarle la retención prevista para pagos con tarjeta crédito y tarjeta débito generarían un recaudo del Impuesto a las ventas por valor de \$3.497 millones, cifra que hoy por hoy se fuga de los ingresos tributarios del país y que, con las modificaciones introducidas con la reforma tributaria realizada mediante la Ley 1819 de 2016, se podrán empezar a recaudar a partir de julio de 2018 .

\section{Impuestos directos e indirectos en la Economía digital para sociedades que operan streaming en algunos países}

\section{A. Impuestos directos}

Adicionalmente al análisis realizado a la legislación doméstica del impuesto de renta respecto a la tributación del mismo por las sociedades extranjeras que proveen streaming en el territorio nacional, se considera pertinente evaluar la tributación de estas sociedades en otras jurisdicciones respecto a este impuesto, incluyendo los países de residencia de las principales proveedoras de streaming en Colombia, como lo son Netflix y Spotify, cuya residencia está en Países Bajos y Estados Unidos.

\section{Impuesto de renta a las sociedades residentes en los Países Bajos}

Según la Ley sobre impuestos corporativos 1969, el impuesto de renta para los residentes se reviste de las siguientes características relevantes, dentro de las cuales se exponen algunas relacionadas directamente con la actividad de la generación de streaming:

- El impuesto corporativo en los Países Bajos es un impuesto directo aplicado a las sociedades residentes y los contribuyentes extranjeros que perciben ingresos en su territorio ${ }^{31}$.

- La tarifa del impuesto corporativo en los Países Bajos oscila entre el $20 \%$ para una cantidad imponible entre $€ 0 \mathrm{y}$ $€ 200.000$, y el $25 \%$ para una cantidad imponible superior a $€ 200.000^{32}$.

- Los Países Bajos son una jurisdicción que ofrece amplia gama de instrumentos que permiten tener ventajas fiscales, por ello es un territorio preferido para la inversión extranjera de multinacionales, que al establecerse en dicha ju-

\footnotetext{
${ }^{30}$ Calculados a partir de las cifras presentadas por DNP en el foro "El futuro del sector audiovisual en el marco de la convergencia tecnológica en Colombia (66,1\% de 70 millones de dólares, calculados a partir de la TRM a 31-12-2015 \$3.149,47).

${ }^{31}$ Capítulo 1. Responsabilidad fiscal Ley sobre impuestos corporativos 1969.

${ }^{32}$ Capítulo 5. Tarifa Ley sobre impuestos corporativos 1969.
} 
risdicción pueden disminuir su carga tributaria mundial, lo que contribuye a la planificación fiscal de dichas compañías. Dentro de los incentivos fiscales otorgados por los Países Bajos, se encuentran:

$\checkmark$ Exención en la participación. Esta exención consiste en la prerrogativa total de los beneficios derivados de la calificación de empresas de participación, e incluye todo tipo de dividendos y ganancia de capital.

$\checkmark$ Red de tratados. Los Países Bajos cuentan con más de 80 tratados para evitar la doble no imposición, suscritos y vigentes, lo cual permite acceder a una rebaja de impuestos de retención sobre dividendos salientes y los dividendos percibidos si califican para la exención de la participación, así como ausencia de retención sobre rentas como regalías e intereses.

$\checkmark$ Cuadro de patentes. Incentivo de I+D, con el cual se establece una tarifa diferencial del $10 \%$ para los ingresos derivados de los activos intangibles de desarrollo propio; se aplica a todos los ingresos generados por el activo intangible, ya sea en la sociedad o dentro del grupo, y se permite la deducción de los costos de producción de los activos intangibles de la base imponible.

$\checkmark$ Doble desgravación fiscal, la cual aplica para los ingresos percibidos en las jurisdicciones con las cuales no se tiene suscrito y vigente CDI. Dicha figura consiste en evitar la situación en que se deba pagar impuestos en varios países, y le otorga el derecho a una desgrava- ción del impuesto sobre la renta en los Países Bajos, la cual no puede exceder el valor del impuesto que deba pagar. Se aplica a partir de dos métodos (método de exención para rentas de salarios; método de compensación para rentas de dividendos, regalías e intereses) (Belastingdienst, s.f.).

- Sin embargo, este país cuenta con una tasa promedio de impuesto a las sociedades, la cual permite que no reúna todas las condiciones para ser calificado como un paraíso fiscal o jurisdicción de baja o nula tributación, pues efectivamente cobra una tarifa de impuesto promedio, aunque no es totalmente transparente la información de las sociedades constituidas en su territorio y no se cuenta con amplios tratados de intercambio de información (Oficina Económica y Comercial de la Embajada de España en La Haya, 2012).

\section{Impuesto sobre la renta a las sociedades en Estados Unidos de América}

La legislación doméstica para el impuesto de renta en los Estados Unidos de América está comprendida en la Ley de Reducción de Impuestos y Empleos, Ley 115-97 del 22 de diciembre de 2017, dentro de la cual se fijan las siguientes características relevantes para este impuesto, entre las que se mencionan algunas relacionadas directamente con la generación de streaming:

- El impuesto de renta de sociedades en Estados Unidos de América es un impuesto directo que grava a los sujetos y sociedades estadounidenses, así como sus sucursales en el exterior, bajo el 
principio de territorialidad ${ }^{33}$. Por su parte, las sociedades extranjeras en Estados Unidos de América están sujetas a impuesto en el país solamente sobre la renta derivada de la actividad ejecutada en el país ${ }^{34}$.

- La tarifa del impuesto de renta en los Estados Unidos de América es del $21 \%$. Adicionalmente, la renta generada en Estados Unidos de América está gravada con el impuesto de renta estatal que oscila entre el $0 \%$ y el $13 \%$, como el caso de California, que es de $8,84 \%^{36}$.

- Igualmente, los pagos realizados a no residentes por concepto de dividendos, intereses, regalías y alquileres, servicios prestados en Estados Unidos de América, se les practica retención en la fuente del $30 \%{ }^{37}$.

- Entre los incentivos fiscales otorgados por Estados Unidos de América, tene$\operatorname{mos}^{38}$ :

$\checkmark$ Deducción del 37,5 \% del ingreso intangible derivado del extranjero hasta el año 2025, y a partir del año 2026 la deducción será del $25 \%$.

$\checkmark$ Deducción del $50 \%$ del ingreso intangible global con bajos impuestos hasta el año 2025, y a partir del año 2026 la deducción será del 37,5.

\section{B. Impuestos indirectos}

De igual forma, aunado al análisis realizado en la legislación doméstica del impuesto al valor agregado que grava las transacciones de licenciamiento de la tecnología de streaming por parte de sociedades extranjeras en el territorio nacional, se considera pertinente analizar lo previsto en la legislación doméstica de otras jurisdicciones respecto a este impuesto, incluyendo en estas los países de residencia de las principales proveedoras de streaming en Colombia, como lo son Netflix y Spotify, cuya residencia está en los Países Bajos y Estados Unidos.

\section{Impuesto al valor agregado en los Países Bajos}

Según la Ley del impuesto sobre el volumen de negocios de 1968, de acuerdo con el sistema de gravamen sobre el valor añadido, el Impuesto al valor añadido en la actividad relacionada con la generación de streaming se reviste de las siguientes características en los Países Bajos:

- Dentro de los hechos imponibles, se considera que el otorgamiento de licencias está categorizado como un

\footnotetext{
${ }^{33}$ Ley de Reducción de Impuestos y Empleos, Ley 115-97 del 22 de diciembre de 2017 que enmienda la Sección 861. Ingresos de fuentes dentro de los Estados Unidos de América.

${ }^{34}$ Ley de Reducción de Impuestos y Empleos, Ley 115-97 del 22 de diciembre de 2017 que enmienda la Sección 882. Impuesto a la renta de corporaciones extranjeras relacionadas con los Estados Unidos de América.

${ }^{35}$ Ley de Reducción de Impuestos y Empleos, Ley 115-97 del 22 de diciembre de 2017 que enmienda la Sección 11. Impuesto en los Estados Unidos de América.

${ }^{36}$ Recuperado de: https://taxfoundation.org/state-corporate-income-tax-rates-and-brackets2015?lien_externe_oui=Continuar.

${ }^{37}$ Ley de Reducción de Impuestos y Empleos, Ley 115-97 del 22 de diciembre de 2017 que enmienda la Sección 1442. Retención de impuestos sobre corporaciones extranjeras.

${ }^{38}$ Ley de Reducción de Impuestos y Empleos, Ley 115-97 del 22 de diciembre de 2017 que enmienda la Sección 250. Ingresos intangibles derivados del extranjero e ingresos globales intangibles con bajos impuestos.
} 
servicio que se encuentra gravado con el impuesto al valor añadido ${ }^{39}$, para efectos de dar aplicación al principio de territorialidad en este impuesto, se considera como lugar de prestación del servicio el domicilio o la residencia habitual del que compra el servicio ${ }^{40}$.

- Los servicios, incluidos dentro de estos el otorgamiento de licencias, se hallan gravados con la tarifa del $21 \%$, la cual constituye la tarifa general del impuesto al valor añadido ${ }^{41}$.

- Al categorizarse el otorgamiento de licencias como un servicio y tenerse previsto como lugar de prestación de servicio el domicilio o residencia habitual del adquiriente, el otorgamiento de licencias cuando se realiza a un adquiriente domiciliado o con residencia habitual en otro Estado se considera una exportación de servicios, la cual se halla exenta del impuesto al valor añadido ${ }^{42}$.

\section{Impuesto al valor agregado en los} Estados Unidos de América

Según el Código de Rentas Internas de los Estados Unidos de América y en concordancia con los códigos y regulaciones estatales ${ }^{43}$, el impuesto a las ventas se cobra a nivel estatal y posee una tarifa según cada estado (véase Ilustración 25).

Igualmente, en la normatividad mentada, se enuncia que el impuesto a las ventas es- tatal solo es aplicable a la venta de bienes y servicios minoristas, y entre los mismos no se encuentra contemplado el otorgamiento de licencias de intangibles.

\section{Análisis de tributación de los impuestos directos e indirectos por Netflix en los Estados de residencia y una eventual doble imposición}

Teniendo en cuenta el tratamiento tributario de las rentas por regalías dado en los Estados de residencia de las principales sociedades extranjeras no residentes en Colombia que proveen streaming en el territorio nacional, se puede advertir que Netflix en el estado de residencia de la filial a través de la cual suscribe más del $80 \%$ de sus acuerdos de licenciamiento de la tecnología de streaming a nivel mundial, tributa así:

\section{Impuestos directos:}

En los Países Bajos, los ingresos por regalías derivados de la explotación de intangibles de desarrollo propio están gravados a una tarifa diferencial del $10 \%$ en virtud del régimen preferencial de Cuadro de Patentes establecido como incentivo de I+D. Las sociedades residentes tributan por renta mundial y se permite la aplicación de tax credit por el método de compensación para descontar los impuestos pagados en otras jurisdicciones por los ingresos por regalías percibidos en los mismos, sin perjuicio de los

\footnotetext{
${ }^{39}$ Capítulo II Tasa por entregas y servicios, Sección 1 Evento imponible, Artículo 4.

${ }^{40}$ Capítulo II Tasa por entregas y servicios, Sección 1b Lugar de un servicio, Artículo 6.

${ }^{41}$ Capítulo II Tasa por entregas y servicios, Sección 2 Tasas de impuestos y tasas, Artículo 9.

${ }^{42}$ Capítulo IV Exportación de bienes y servicios, Artículo 24.

${ }^{43} \mathrm{https}$ //gobierno.usa.gov/tipos-impuestos.
} 
Ilustración 25.

Tasas estatales del impuesto a las ventas en Estados Unidos de América

\section{STATE SALES TAX RATES \\ AND FOOD \& DRUG EXEMPTIONS}

(As of January 1, 2018)

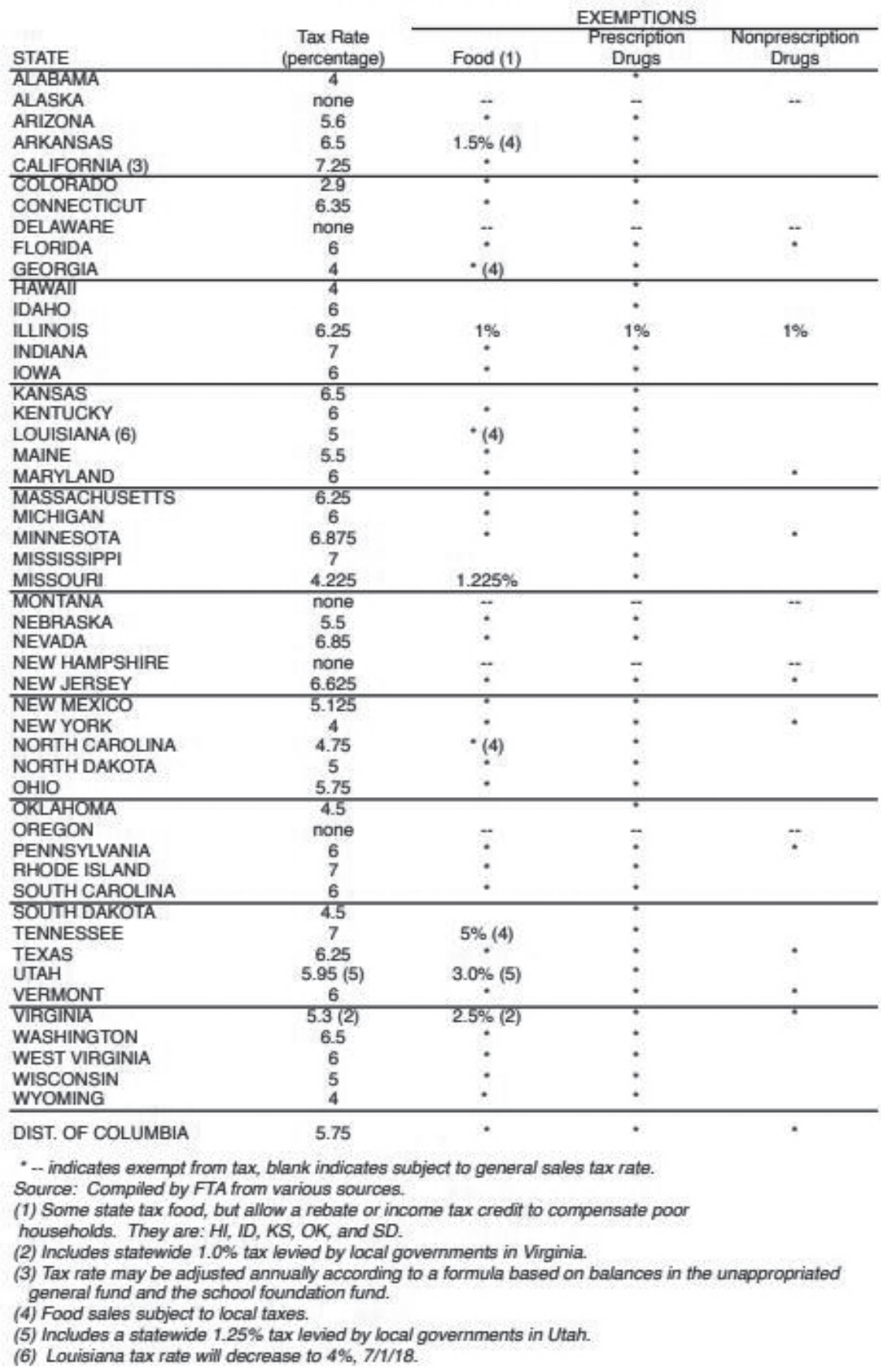

Fuente: https://www.usa.gov/state-taxes. 
métodos que prevea un convenio para evitar la doble imposición suscrito.

\section{Impuestos indirectos:}

En los Países Bajos, los ingresos por licenciamiento de intangibles u otorgamiento de licencias son categorizados como servicios, sobre los cuales solo generan el IVA los prestados en el mismo Estado; los prestados en las otras jurisdicciones se consideran exportación de servicios, y se encuentran exentos del IVA.

Bajo este entendido, se puede advertir que al aplicar el impuesto de renta y el IVA sobre los ingresos percibidos por Netflix por la suscripción de acuerdos de licenciamiento de la tecnología de streaming en el territorio nacional, no se estaría incurriendo en una doble imposición de estos tributos, pues es claro que respecto al impuesto directo el país de residencia cuenta con una medida unilateral de mitigación de la doble imposición, como es el tax credit, y respecto al impuesto indirecto, el mismo no se tributa por este tipo de renta cuando es originada a través de exportación, condición que resulta aplicable a los ingresos percibidos por Netflix en el Estado colombiano.

\section{Referencias}

Agencia Nacional de Televisión - ANTV (2017). La televisión servicio público. Recuperado de: https://www.antv.gov.co/index.php/tramites-y-servicios/2016-05-19-16-37-13/conozca-sus-derechos/ item/45-la-television-es-un-servicio-publico

Agencia Nacional de Televisión - ANTV (2017). La televisión servicio público. Recuperado de: https://www.antv.gov.co/index.php/tramites-y-servicios/2016-05-19-16-37-13/conozca-sus-derechos/ item/45-la-television-es-un-servicio-publico
Aguilar, L. J. (2012). Computación en la nube: estrategias de cloud computing en las empresas. México D.F., México: Alfaomega.

Álamo, R. y Lagos, M. (2012). Adaptación del IVA a las transacciones comerciales electrónicas (Seminario de grado, Universidad de Castilla, La Mancha, Cuenca). Recuperado de https://previa.uclm.es/Cu/csociales/pdf/ documentosTrabajo/2012/7.pdf.

Almudí, J.; Blanco Dalmau, A.; Bunes Ibarra, J.; Bustamante Esquivias, M.; Bustos Buiza, J. y Calleja Crespo, A..., Velayos Jiménez, F. (2004). Manual de fiscalidad internacional. Colección Manuales de la Escuela de la Hacienda pública. Recuperado de http:// www.ief.es/documentos/recursos/publicaciones/libros/ Manuales_hac_publica/Libros_Manu_Escue_Hac_ Publ_FiscaliInter_Indi.pdf.

Amazon Web Services, Inc. - AWS (2017). Infraestructura global de AWS. Recuperado de: https://aws.amazon. com/es/about-aws/global-infrastructure/

Apple.com. 2017. Acera de ITunes. Recuperado de: https://www.apple.com/la/itunes/.

Arévalo,Z. (2012). Artículo Tratamiento tributario de las regalías obtenidas por la explotación de propiedad industrial: una mirada desde el Derecho tributario internacional. Recuperado de: http://revistas.uexternado. edu.co/index.php/fiscal/article/view/3066/2715.

Arteaga, U. (2016). Post NETFLIX solo gana con los usuarios de Estados Unidos. Recuperado de: https:// es.statista.com/grafico/6103/netflix-solo-gana-con-losusuarios-de-estados-unidos/.

Asociación Española de Comercio Electrónico y Marketing Relacional (s. f). Libro Blanco del Comercio Electrónico. Recuperado de http://www.femeval.es/ informesymanuales/Documents/AECEM_Libro_Blanco.pdf.

Asociación Española de la Economía Digital (s. f). Guía sobre IVA en comercio electrónico en la Unión Europea. Recuperado de https://www.adigital.org/ media/guia-iva-ecommerce-ue.pdf.

Boletín Foro Fiscal Iberoamericano (2015). La Economía digital y su tributación. Recuperado de http://www. ief.es/documentos/recursos/publicaciones/revistas/ foro_fiscal/Foro21_2015.pdf.

Buda.com (2017). Términos de uso Buda. Recuperado de: https://www.buda.com/terminos-y-condicio nes\#?market=btc-clp. 
Buitrago, E. (2005). Derecho al día. Calificación de los ingresos por derecho de autor y conexos en los tratados por evitar la doble imposición sobre la renta, 76. Recuperado de: http://www.derecho.uba.ar/derechoaldia/ notas/la-calificacion-de-los-ingresos-por-derecho-deautor-y-conexos-en-los-tratados-por-evitar-la-dobleimposicion-sobre-la-renta/+799.

Buitrago, E. (2009). "Calificación de programas de ordenador en el Derecho tributario ¿Jugando a la ruleta rusa?", Revista Derecho Privado, 42, 3-21. Recuperado de: http://www.redalyc.org/pdf/3600/360033191005. pdf.

Cabrera, O. (2017). "Aspectos tributarios de las plataformas digitales en Colombia: Actualidad y retos", en Revista de Derecho fiscal (10), 85-101. Doi: https:// doi.org/10.18601/16926722.n10.06.

Calvo, J. (2010). La aplicación del IVA en el ámbito del comercio electrónico. (135). Recuperado de http:// www.ief.es/documentos/recursos/publicaciones/revistas/cron_trib/135_Calvo.pdf.

Cámara Colombiana de Comercio Electrónico (2015). Tercer estudio de transacciones no presenciales de eCommerce. Recuperado en https://www.ccce.org.co/ sites/default/files/biblioteca/Infograf\%C3\% ADa\%20 Tercer $\% 20$ estudio $\% 20$ de $\% 20$ transacciones $\% 20$ no $\% 20$ presenciales-eCommerce\%202015_0.pdf.

Cámara Colombiana de Comercio Electrónico (2016). Tercer Estudio de Transacciones no Presenciales de 2015. Bogotá D.C. Recuperado de: https:// www.ccce.org.co/sites/default/files/biblioteca/Info graf $\%$ C $3 \%$ ADa $\% 20$ Tercer $\% 20$ estudio $\% 20$ de $\% 20$ transacciones $\% 20$ no $\% 20$ presenciales-eCommerce $\% 20$ 2015_0.pdf.

Castañeda, J. (s. f.). Aplicación del IVA en Colombia. Recuperado de http://www.shd.gov.co/shd/sites/default/files/files/contabilidad/iva.pdf.

Cehis.com. (2013). Posted en Ayuda video streaming. Recuperado de: http://cehis.net/sitio/ayuda-videostreaming/asistencia-y-soporte/base-de-conocimientofaq/ayuda-video-streaming/que-es-y-para-que-sirveel-streaming

Colombia Telecomunicaciones S.A. ESP (2017). Contrato de servicio de televisión. Recuperado de: https:// www.movistar.co/documents/10184/561805/Contrato +de+Servicios+de+Televisi\%C3\%B3n.pdf/42780e4d237b-4fea-a70e-6d351048a15e.

Comisión Europea (2011). Comunicación de la Comisión al Parlamento, al Concejo y al Comité Económico y Social Europeos: La doble imposición en el mercado único. Recuperado de http://eur-lex.europa. eu/legal-content/ES/TXT/PDF/?uri=CELEX:52011DC07 $12 \&$ from $=$ ES.

Comisión Europea (2011). Comunicación de la Comisión al Parlamento, al Concejo y al Comité Económico y Social Europeos: Sobre el futuro del IVA hacia un sistema de IVA más simple, robusto, eficaz y adaptado al mercado único. Recuperado de http:// ec.europa.eu/taxation_customs/common/consultations/ tax/2010_11_future_vat_en.htm.

Conferencia de las Naciones Unidas sobre Comercio y Desarrollo (2015). Informe sobre la Economía de la información 2015: Liberar el potencial del comercio electrónico para los países en desarrollo. Recuperado de http://unctad.org/es/PublicationsLibrary/ ier2015_es.pdf.

Congreso de la República de Colombia (18 de agosto de 1999). Ley de Comercio Electrónico [Ley 527 de 1999]. DO: 43.673.

Congressional Research Service (2016). The Internet Tax Freedom Act: In brief. Recuperado de https://fas. org/sgp/crs/misc/R43772.pdf.

Consejo Nacional Legislativo de la República de Colombia (26 de mayo de 1873). Código Civil [Ley 84 de 1873]. DO: 2.867.

Deezer.com (2017). Acerca de Deezer. Recuperado de: https://www.deezer.com/mx/company.

Departamento Nacional de Planeación (2016). Foro El futuro del sector audiovisual. Recuperado de: https://www.dnp.gov.co/Paginas/DNP-proponerevolc\%C3\% B3n-en-regulaci\%C3\%B3n-TIC-yaudiovisual-en-Colombia.aspx.

Dirección de Impuestos y Aduanas Nacionales (2001). Concepto 68810 de 2001. Recuperado de: http://forvm. com.co/concepto-numero-68810-de-30-07-2001-diancompras/.

Dirección de Impuestos y Aduanas Nacionales (2008). Concepto 60826 de 2008. Recuperado de: https://cijuf. org.co/codian08/junio/o60826.html.

Dirección de Impuestos y Aduanas Nacionales (2010). Concepto 69307 de 2010. Recuperado de: https://cijuf. org.co/normatividad/concepto/2010/concepto-69307. html.

Dirección de Impuestos y Aduanas Nacionales (2015). Concepto 24193 de 2015. Recuperado de: https://w ww.redjurista.com/Document.aspx ?ajcode=of_dian _24193_2015\#/. 
Dirección de Impuestos y Aduanas Nacionales (2017). Cifras estadísticas. Recuperado de: http://www.dian. gov.co/contenidos/cifras/estadisticas.html.

Directiva 2002/38/CE del Concejo. "Por la que se modifica temporalmente la Directiva 77/388/CEE respecto del régimen del impuesto sobre el valor añadido aplicable a los servicios de radiodifusión y de televisión y a algunos servicios prestados por vía electrónica", en Diario Oficial de las Comunidades Europeas No. 128, del 15 de mayo del 2002. Unión Europea.

Ecommerce platforms (2015). E-Commerce Goes Global.An Infographic. (London) U.K. Recuperado de: http://ecommerce-platforms.com/ecommerce-news/ecommerce-goes-global-an-infographic.

EY Bulding (2015). Tiempos de Cultura. Recuperado de: http://www.worldcreative.org/wp-content/uploads /2016/03/ EYCulturalTimes2015 _ES_Download.pdf.

Hoyos, C. (2005). Tributación de intangibles en Colombia. XXIX Jornadas Colombianas de Derecho Tributario, Cartagena de Indias, Instituto Colombiano de Derecho Tributario.

Hulu.com (2017). Acerca de Hulu. Recuperado de: https://www.hulu.com/press/about/

Internet world stats. 2014. Internet users in the world distribution by world regions - 2014. U.S. Recuperado de: http://www.internetworldstats.com/.

Intranet Educativa Municipal del Ayuntamiento de La Coruña (2017). Ondas Electromagnéticas. Recuperado de: http://teleformacion.edu.aytolacoruna.es/FISICA/document/fisicaInteractiva/Ondasbachillerato/ondasEM/ ondasEleMag_indice.htm.

Investing.com (2017). Netflix Inc. (NFLX) Nasdaq. Recuperado de: https://es.investing.com/equities/ netflix,-inc.-income-statement.

Irribarra, E. (2016). "La equidad tributaria en el comercio digital según la OCDE, y sus desafíos para la recaudación fiscal", en Revista de estudios tributarios (14), pp. 241-270. Recuperado de https:// revistaestudiostributarios.uchile.cl/index.php/RET/ article/view/40287/41840.

Joyares, L. (2013). Computación en la nube: estrategias de cloud computing en las empresas. Barcelona, España. Recuperado de: https://dialnet.unirioja.es/ descarga/articulo/4098278/1.pdf.
KPCB Internet Trends (2016). Global internet users, 2008-2015. San Francisco, Estados Unidos. Recuperado de: http://www.kpcb.com/blog/2016-internettrends-report.

Labrada, F. (2015). Proyecto plataforma de coordinación regional para la distribución audiovisual.(1ra.Ed). Bogotá: Recuperado de http://www.mincultura.gov.co/ areas/cinematografia/publicaciones/Documents/Plataformas\%20Digitales\%20-\%20F.\%20LABRADA.pdf.

Laman, B.(s.f.). European value added tax (Vat). Recuperado de https://www.bkd.com/docs/solution-sheets/ european-value-added-tax.pdf.

Lamensch, M. (2015). European value added tax in the digital era. Recuperado de https://www.ibfd.org/sites/ ibfd.org/files/content/pdf/15_075_European-ValueAdded-Tax-Digital-Era_final_web_0.pdf.

Bonilla Montoya, L. E. (2017). “Análisis de las acciones BEPS, su aplicación en Colombia y su inclusión al sistema tributario", en Revista Instituto Colombiano de Derecho Tributario 76. Mayo de 2017. At. 157.

Marín, M. (2004). "Impuestos al comercio electrónico (e-fiscalidad): la problemática fiscal del impuesto al valor agregado (IVA)", en Revista de Derecho Fiscal (2). Recuperado de ¿??

Martínez, M. (2010). Tratamiento tributario actual del comercio electrónico en la República Argentina (Tesis de grado, REDI- Universidad de fasta, Argentina). Recuperado de http://redi.ufasta.edu.ar:8080/xmlui/ bitstream/handle/123456789/287/2010_CP_004. pdf? sequence $=1$.

Mejías, E. (2017). Suscripción: Modelos de Negocio. Sevilla, España. Recuperado de: https://www. orientadorweb.com/modelo-de-suscripcion/.

Meraz, A. (2006). Aspectos jurídicos como comercio electrónico, como comercio transnacional. (Memoria Doctorado, Universidad Complutense, Madrid). Recuperado de http://eprints.ucm.es/7391/1/T29290. pdf.

Ministerio de Educación, Política Social y Deporte de España; Instituto Superior de Formación y Recursos en Red para el Profesorado. (2008). Formación en Red. ¿Qué es el streaming? Recuperado de: http://www. ite.educacion.es/formacion/materiales/107/cd/video/ video0103.html. 
Ministerio de energía, turismo y agenda digital de España (2017). Televisión digital. Recuperado de: http://www.televisiondigital.gob.es/TelevisionDigital/ Paginas/television-digital.aspx.

Monroy, M. (2013). Tratado de Derecho internacional privado. $7^{\mathrm{a}}$ ed. Bogotá. Editorial Temis.

Montoya. J. (2015). "El streaming va imparable", en El colombiano.com. Recuperado de: http://www.elcolombiano.com/tecnologia/el-streaming-va-imparableIJ2784749.

Moreno, G. (2017). Post ¿Desde qué países hay acceso a Netflix? Recuperado de: https://es.statista.com/ grafico/8930/desde-que-paises-hay-acceso-a-netflix/.

Moreno, G. (2017). Post Netflix sorprende a Wall Street. Recuperado de: https://infographic.statista. com/normal/chartoftheday_6276_netflix_sorprende_a_ wall_street_n.jpg.

Muñoz, G. y Zornoza, J. (2015). "La aplicación de las normas tributarias", en La Obligación Tributaria y sus Fundamentos Constitucionales. Bogotà Universidad Externado de Colombia, pp. 207-270.

Muñoz, G.; Medina, A.; Domínguez, A.; Ordóñez, E.; Insignares, R.; Castro, J., Castellanos, M. En J. R. Piza (Eds.) (2015). Análisis del hecho generador del IVA en el ordenamiento jurídico colombiano. Bogotá: Universidad Externado de Colombia.

Negociación de acuerdos de licencia de tecnología. (Ginebra) Suiza. Recuperado de: http://www.wipo.int/ edocs/pubdocs/es/licensing/906/wipo_pub_906.pdf.

Netflix (2017a). Acerca de Netflix. Recuperado de: https://media.netflix.com/es/about-netflix.

Netflix (2017b). Cómo trabaja Netflix con los proveedores de servicios de internet de todo el mundo para ofrecer mejor experiencia visual. Recuperado de: https://media.netflix.com/es_es/company-blog/hownetflix-works-with-isps-around-the-globe-to-delivera-great-viewing-experience.

Netflix (2017c). Informe SEC 2016. Recuperado de: https://ir.netflix.com/secfiling.cfm?filing ID =1628280$17-496 \&$ CIK $=1065280$.

Netflix (2017d). Términos de Uso. Recuperado de: https://help.netflix.com/legal/termsofuse

Nieto,P. (2009). "Nociones generales sobre el comercio electrónico", en Revista virtual. Centro de estudio derecho y tecnología Universidad San Martin de Porres.
(Lima) Perú. Recuperado de: http://www.derecho. usmp.edu.pe/cedetec/articulos.html.

Núñez,F. (2006). "Precios de transferencia y comercio electrónico en España”, en Revista galena de economía, 15 (2), 1-21. Recuperado de http://www.redalyc.org/ articulo.oa?id=39115207.

Observatorio eCommerce de Foro de Economía Digital (2014). Informe de evolución y perspectivas eCommerce 2015. Recuperado de http://www.ey.com/ Publication/vwLUAssets/Evoluci\%C3\%B3n_y_perspectivas_eCommerce_2015/\$FILE/EY-Informe-Tendencias_eCommerce-2015.pdf.

Oficina Económica y Comercial de la Embajada de España en La Haya (2012). Sistema fiscal en Países Bajos. Recuperado de: http://observatoriorli.com/docs/ PAISES_BAJOS/FISCALIDAD_Paises_Bajos.pdf.

Organización Mundial de la Propiedad Intelectual OMPI (2011).¿Qué es la propiedad intelectual? Ginebra, Suiza. Recuperado de: http://www.wipo.int/edocs/ pubdocs/es/intproperty/450/wipo_pub_450.pdf.

Organización para la Cooperación y el Desarrollo económicos - OCDE (2012). Modelo de Convenio Tributario sobre la Renta y sobre el Patrimonio. Recuperado de: http://www.oecd-ilibrary.org/taxation/ modelo-de-convenio-tributario-sobre-la-renta-y-sobreel-patrimonio-version-abreviada_9789264184473-es.

Organización para la Cooperación y el Desarrollo Económicos (OCDE) (2012). Tributación fiscal y comercio electrónico: Implantación del marco tributario de la conferencia Ottawa. Recuperado de http://www.oecd. org/tax/administration/2673607.pdf.

Organización para la Cooperación y el Desarrollo Económicos (OCDE) (2014). Cómo abordar los desafíos fiscales de la Economía Digital. París, Francia. Recuperado de: https://www.oecd.org/ctp/Action-1-DigitalEconomy-ESP-Preliminary-version.pdf.

Ortiz, E. (2017). "Consideraciones conceptuales de incidencia económica y de estructura jurídica de impuesto sobre las ventas en Colombia, presupuestos de ejecución, no sujeción y exoneraciones", en $R e$ vista de Derecho Fiscal (10), 7-25. doi: https://doi. org/10.18601/16926722.n10.02.

Oviedo, A. (2012). 2La ley aplicable a los contratos internacionales. International Law", en Revista Colombiana de Derecho Internacional. Recuperado de: http://www.redalyc.org/articulo.oa?id=82425523005. 
Owens J. (01 de enero de 2000). "El comercio electrónico y la tributación", en Boletín Afip No. 30. Recuperado de https://es.scribd.com/document/210283568/apuntesEl-Comercio-Electronico-y-La-Tributacion.

Paraísos Fiscales.Info (s.f). Política de privacidad. Recuperado de http://www.paraisos-fiscales.info/ content/2-politica-de-privacidad.

Parlamento Europeo (2015). Sobre el informe anual sobre la Fiscalidad 2014/2144(INI)). Recuperado de http://www.europarl.europa.eu/sides/getDoc. do? pubRef=-//EP//NONSGML+REPORT+A8-20150040+0+DOC+PDF+V0//ES.

PayU Latam.com (2017). Términos de uso PayU. Recuperado de: https://www.payulatam.com/imagenescorreos/pdfs/PayU\%20T\&C\%20para\%20 Comercios\%20ES.pdf.

PayU. (2016). Reporte 2016: La Geografía de los pagos en el mercado colombiano. (E-Book). Recuperado de https://www.payulatam.com/co/la-geografia-de-lospagos-en-el-mercado-colombiano/ pendiente como fue descargado?

Presidencia de la República de Colombia (11 de octubre de 2016). Decreto único reglamentario en materia tributaria [Decreto 1625 de 2016]. DO: 50.023.

Presidencia de la República de Colombia (14 de marzo de 2001). Decreto reglamentario Ley 633 de 2000 y Estatuto Tributario [Decreto 406 de 2001]. DO: 44.358.

Presidencia de la República de Colombia (23 de junio de 1989). Decreto reglamentario de la inscripción de soporte lógico (software) en el Registro Nacional del Derecho de Autor [Decreto 1360 de 1989]. DO: 38.871.

Presidencia de la República de Colombia (27 de diciembre 2016). Reforma Tributaria [Ley 1819 de 2016]. DO: 50.101.

Presidencia de la República de Colombia (27 de marzo de 1971). Código de Comercio [Decreto 410 de 1971]. DO: 33.339 .

Presidencia de la República de Colombia (30 de marzo de 1989). Estatuto Tributario [Decreto 624 de 1989]. DO: 38.756 .

Presidencia de la República de Colombia (30 de marzo de 2001). Decreto reglamentario Ley 633 de 2000 y Estatuto Tributario [Decreto 556 de 2001]. DO: 44.380.

Real Academia Española (2017). Significado de recepcionar. Recuperado de: http://lema.rae.es/damer/srv/ search?key=recepcionar.
Real Academia Española (2017). Significado de difundir. Recuperado de: http://dle.rae.es/srv/ fetch?id=DkTKH1I.

Real Academia Española. 2017. Significado de distribuir. Recuperado de: http://dle.rae.es/srv/ search?m=30\&w=distribuir.

Real Academia Española (2017). Significado de transmitir. Recuperado de: http://dle.rae.es/srv/fetch?id= aLjNpvi.

Real Academia Española (2017). Significado de emitir. Recuperado de: http://dle.rae.es/srv/search?m=30\&w $=$ emitir.

Red de Investigación Educativa - IeRed (2012). Licencias de uso. Recuperado de: http://www.iered.org/ miembros/ulises/representacion-ideas/Derechos-Autor/ licencias_de_uso.html.

Reino de los Países Bajos, Ministerio de Finanzas (8 de octubre de 1969). Ley sobre impuestos corporativos [Ley de 8 de octubre de 1969]. Boletín de hechos: 28 de octubre de 1969.

Rengifo, A. (2002). El establecimiento permanente en un contexto virtual. Bogotá: Universidad Externado de Colombia. Recuperado de: http://revistas.uexternado. edu.co/index.php/emerca/article/view/2163/1915.

Rimola, O. (2005). Algunas particularidades tributarias relativas al comercio electrónico. Recuperado de http://www.eumed.net/ce/2005/orc-ce.htm.

Satoshi Nakamoto. (s.f). Bitcoin: un sistema de dinero en efectivo electrónico peer-to-peer. Recuperado de https://bitcoin.org/files/bitcoin-paper/bitcoin_es.pdf

Satoshi Nakamoto. (s.f.-a). Bitcoin: un sistema de efectivo electrónico Usuario-a-Usuario. Recuperado de https://bitcoin.org/files/bitcoin-paper/bitcoin_es_latam.pdf.

Senado y Cámara de Representantes de los Estados Unidos de América (22 de diciembre de 2016). Ley de Reducción de Impuestos y Empleos [Ley 115-97 del 22-dic-16]. Pub. L 99-514. 100 STAT.2015.

Sistema Único de Información del Sector de Telecomunicaciones - SIUST. (2017). Acceso Fijo de Internet en Colombia. Ministerio de Tecnologías de la Información y Telecomunicaciones. Recuperado de http://colombiatic.mintic.gov.co/602/articles-60285_archivo_pdf.

Spotify.com (2017). Acerca de Spotify. Recuperado de: https://press.spotify.com/co/about/. 
Spotify.com (2017). Términos y Condiciones de uso de Spotify. Recuperado de: https://www.spotify.com/ co/legal/end-user-agreement/.

Sternberg, A. (s.f). Principio de tributación en el país de destino. Recuperado de https://es.scribd.com/ document/331779098/7179-Principio-de-Tributacionen-El-Pais-de-Destino.

Teleformacion.edu. 2017. Ondas electromagnéticas. Recuperado de: http://teleformacion.edu aytolacoruna. es/FISICA/document/fisicaInteractiva/Ondasbachillerato/ondasEM/ondasEleMag_indice.htm.

Urrutia, C. (2014). Impuesto sobre las ventas y generalidades del Impuesto al consumo, una visión desde la reforma más polémica. (Diploma de grado, Universidad Militar Nueva Granada, Colombia). Recuperado de http://repository.unimilitar.edu.co/ bitstream/10654/12684/1/ENSAYO\%20FINAL \%20-\%20 CLAUDIA\%20URRUTIA.pdf.

Villalba, J. (2008). "Contratos por medios electrónicos. Aspectos sustanciales y procesales", en Revista Prolegómenos. Derechos y Valores de la Universidad Militar Nueva Granada. Recuperado de: http://www.redalyc. org/pdf/876/87602207.pdf.

Visa (s.f). Informe sobre e-Readiness en Latinoamérica 2014. Recuperado de http://promociones.visa.com/lac/ ecommerce/es/index.html. 